\title{
FUNDAMENTOS ONTOLÓGICOS \\ EN LA FILOSOFÍA INTERCULTURAL DE RAÚL FORNET-BETANCOURT
}

\author{
JHONNATHAN CHACÓN MONTES \\ CÓDIGO: 1030620636
}

DIRECTOR

JUAN CEPEDA H.

FACULTAD DE FILOSOFÍA Y LETRAS

MAESTRÍA EN FILOSOFÍA LATINOAMERICANA

2019 
Dedicatoria:

A mi madre. 


\title{
Agradecimiento:
}

Un reconocimiento especial a mi madre quien con su esfuerzo me dedicó todo su apoyo y permaneció a mi lado en los momentos en que necesité una voz de aliento.

A mi padre y a mis hermanas por su respaldo en este proceso de investigación.

\begin{abstract}
A la Universidad Santo Tomás, en especial a la Maestría en Filosofía Latinoamericana, a los compañeros con quienes compartí y afortunadamente, coincidí. Así como a los profesores de quienes aprendí y crecí tanto a nivel académico como humano.
\end{abstract}

Por último, a mi director de investigación, el profesor Juan Cepeda H., por haberme guiado en mi propuesta y brindar siempre aportes invaluables en la construcción de este proyecto que, sin duda, deja abiertos nuevos senderos y posibilidades de sentir-pensar el ser. 


\section{TABLA DE CONTENIDO}

INTRODUCCIÓN

1. MARCO TEÓRICO 9

1.1. En búsqueda del ser 9

1.2. Ontología latinoamericana 14

1.3. Ontología intercultural 22

$\begin{array}{ll}\text { 1.4. Filosofía intercultural } & 27\end{array}$

2. ONTOLOGÍAS DE NUESTRA AMÉRICA 36

2.1. Ontología del mestizaje como principio intercultural 37

2.2. Hacia una metafísica ontológica original 42

2.3. Ontología Andina, una relacionalidad ancestral $\quad 44$

2.4. Habencia, ontología libertaria $\quad 48$

2.5. Ontología de la estancia, una fuerza telúrica $\quad \mathbf{5 0}$

2.6. Sentipensar ontológico, recogimiento del fruto ontológico en América Latina 54

2.6.1. Fuerza primera $\quad 56$

2.6.2. Rítmica óntico-anímico-espiritual $\quad 60$

$\begin{array}{ll}\text { 2.6.3. Fuerza rítmica autopoiética } & 62\end{array}$

2.6.4. La cosecha del fruto ontológico $\quad 64$

3. LA FILOSOFÍA INTERCULTURAL DE RAÚL FORNET-BETANCOURT EN CLAVE ONTOLÓGICA

$\begin{array}{ll}\text { 3.1 Humanitas } & 67\end{array}$

$\begin{array}{ll}\text { 3.2 De la feminidad ontológica } & 75\end{array}$

$\begin{array}{ll}\text { 3.3 Espiritualidad latinoamericana } & \mathbf{7 8}\end{array}$

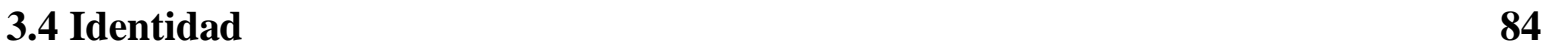

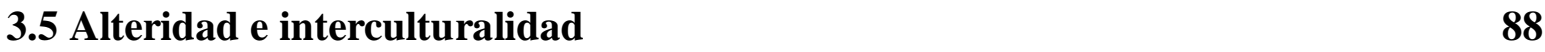

4. CONCLUSIONES

REFERENCIAS BIBLIOGRÁFICAS 


\section{INTRODUCCIÓN}

En América Latina la pregunta por el sentido del ser ha tenido importantes representantes que han dado diversas interpretaciones desde la filosofía, enfocadas por supuesto desde un contexto particular que deviene de la realidad cultural encarnando lo latinoamericano. Ante esto es posible empezar por corroborar que la filosofía, desde este contexto, no se reduce netamente a corrientes como la filosofía de la liberación, la historia de las ideas o la hermenéutica analógica que, si bien han sido fundamentales para el desarrollo de la filosofía propia de América Latina, no son los únicos ejes sobre los cuales se puede auscultar la realidad. De esta manera, filósofos como Vasconcelos, Basave, Bacca, Kusch, Estermann, Cepeda entre otros, han dedicado su producción filosófica a desentrañar la pregunta originaria de la filosofía, la pregunta por el ser, desde una vertiente profundamente latinoamericana.

La filosofía latinoamericana ha venido constituyéndose, particularmente desde mediados del siglo XIX con el conocido discurso en 1842 de Juan Bautista Alberdi y gracias al aporte de diversas influencias culturales como la tradición occidental traída por los conquistadores, las sabidurías ancestrales de los pueblos indígenas autóctonos y la riqueza cosmogónica afro de los esclavos traídos a América que han aunado sentires diversos hasta alcanzar a proponer

disciplinas como la historia de las ideas filosóficas, la filosofía de la liberación, la hermenéutica analógica, la filosofía amerindia y la filosofía intercultural.

La filosofía intercultural, precisamente, será la que abra el horizonte de investigación que aquí nos convoca a través del filósofo cubano Raúl Fornet-Betancourt, quien desde su movimiento filosófico denominado "filosofia intercultural" ha brindado aportes importantes a la apertura cognitivo-cultural de otras formas alternas de concebir, sentir e interpretar la realidad, la filosofía y sus concepciones, más allá del despliegue hegemónico que la historia de la filósofa ha instaurado ad hoc en las periferias culturales o mal llamados países de tercer mundo. 
La filosofía intercultural ha avanzado de manera significativa y ha ido defendiendo su puesto en la palestra filosófica mundial; sin embargo, hace falta evidenciar la fundamentación ontológica que de fondo enriquece esta apuesta y por ello, este proyecto de investigación busca avanzar en esta línea, intentando dar respuesta al vacío del que todavía adolece la filosofía intercultural, más aún cuando se trata de quien es considerado el principal autor de esta empresa filosófica: el pensador Raúl Fornet-Betancourt.

Las apuestas filosóficas, inherentes a los asuntos epistemológicos, ético-políticos, estéticos, lingüísticos, ontológicos y, en general, a la existencia universal, abren las posibilidades para que una investigación como la aquí propuesta tenga sentido; sobre todo, si el interés está centrado en el sustrato ontológico que el mismo Fornet-Betancourt nos permite entrever, teniendo en cuenta que la filosofía intercultural de nuestro autor ha sido desarrollada desde dos horizontes, uno ético-político y otro epistemológico, sin que sea evidente el aspecto ontológico, razón por la cual un proyecto en torno a la visibilización de los aspectos ontológicos de una filosofía en este sentido, enriquecen tanto la filosofía intercultural misma como los horizontes del pensamiento latinoamericano que desde grupos de investigación, en especial Tlamatinime de la Universidad Santo Tomás con sede en Bogotá, intentan comprender.

Los análisis y postulados ontológicos que se pretenden analizar en la filosofía intercultural de Fornet-Betancourt, giran en torno a las relaciones conceptuales con los autores que puedan tener una relación cercana a sus obras, en referencia con el tema central, a saber: la interculturalidad, para lograr concretar las diversas miradas hacia una perspectiva ontológica. Sea esta una oportunidad para ampliar el horizonte de la filosofía en el encuentro sentipensante de las culturas, así como una posibilidad para expandir a nivel cognitivo el radio de acción que representa la filosofía intercultural.

La construcción de los pilares que fundamentan una ontología en el marco del pensamiento intercultural de Raúl Fornet-Betancourt, hacen que este sea el primer acercamiento hacia un 
proyecto de esta índole, razón por la cual nos serviremos de la hermenéutica textual como método de investigación con el fin de alcanzar una lectura rigurosa de las diversas obras del autor principal mediada por la mirada ontológica y enriquecida por los autores abordados en lo que será el capítulo dos.

Por ende, se busca encontrar la relación conceptual de la filosofía propuesta por FornetBetancourt, desde una mirada alterna a los conceptos originarios en la apuesta filosófica de dicho autor, entablando el diálogo desde un horizonte sabedor propio de las culturas de América Latina, que abren y posibilitan otras comprensiones del ser, ampliando no solo la multiplicidad del pensamiento sino también de los lenguajes que designan una filosofía intercultural en concepciones como: La Humanitas, de la feminidad ontológica, la espiritualidad, la identidad y la alteridad e interculturalidad como forma de vida, desde donde es posible hallar un abanico de posibilidades al vislumbrar nuevas formas de comprensión del ser.

Está claro que la filosofía intercultural se encuentra adscrita a cimientos ético-políticos y epistemológicos, sin embargo, en una lectura atenta y juiciosa de los textos de FornetBetancourt podemos ver que nos ofrece algunas luces para preguntarnos cuestiones como ies posible que también, de fondo, haya un sustento ontológico a la hora de buscar la comprensión intercultural de la filosofía?, o mejor, de las filosofías propias de cada una de las culturas que enriquecen precisamente dicha apuesta ¿cuáles serían las categorías fundamentales que la sustentan?

Tales cuestionamientos elementales para alcanzar los logros propuestos a través de la presente investigación, sustentan el compendio capitular de cuatro bloques temáticos sobre los cuales también se despliegan algunos subtemas indispensables para el desarrollo de esta propuesta, los cuales se encuentran distribuidos de la siguiente manera:

El primer capítulo contiene el marco teórico, desglosado en una primera parte que pretende un breve desarrollo de los postulados ontológicos desde donde parte nuestra concepción de 
ontología del ser, a saber, la búsqueda del ser, de la ontología latinoamericana, la ontología intercultural y la filosofía intercultural.

El segundo capítulo, denominado Ontologías de nuestra América recoge y profundiza las principales apuestas filosóficas alrededor de la ontología desde América Latina concedida por diversos filósofos que, con sus particulares construcciones ontológicas, intentan dar respuesta a la pregunta por el ser permeados por contextos geoculturales de enunciación cuyo sentido denota una transformación de la ontología clásica hacia una dinámica rítmica propia de los espacios geográficos latinoamericanos que invitan a auscultar el ser desde nuestros saberes propios al tiempo que resignifican el valor de la cultura imprescindible en la tarea filosófica. Adicionalmente, tendremos en cuenta los postulados de Heidegger pasando por Estermann, Kusch, Cepeda, entre otros autores que abordan argumentos ontológicos y dan pie a que abordemos en el tercer capítulo los fundamentos ontológicos de la filosofía intercultural de Fornet-Betancourt.

Para el tercer capítulo fueron seleccionadas algunas obras del marco teórico en un intento por desocultar los sustratos ontológicos desde una perspectiva latinoamericana adscritos a la llamada intercultural de Fornet-Betancourt, que dé paso a futuros estudios en correlación filosofía intercultural y ontología, como ejes necesarios para la consolidación y expansión de la filosofía latinoamericana.

Por último, en el cuarto capítulo se hallan las conclusiones de la investigación, que buscan develar en definitiva un horizonte nuevo de comprensión de la ontología a la luz de la filosofía intercultural, lo cual sin duda podría ser un aporte a la filosofía en general y al grupo de investigación Tlamatinime sobre ontología latinoamericana, para abrir su campo de acción investigativa y seguir avanzando proyectos académicos en la inacaba diversidad cultural impresa en la identidad de América Latina. 


\section{MARCO TEÓRICO}

Para iniciar, en este capítulo se ofrece el marco teórico de la presente investigación, por ello, primero se entrega el panorama general de la ontología a la luz de una apuesta contemporánea a través, en este caso, de las obras del filósofo Martín Heidegger; dando continuidad con dicha apuesta, se presenta en seguida, el horizonte ontológico que se ha venido profundizando en América Latina, a la luz de los avances otorgados por el Grupo de Investigación Tlamatinime y, dentro de esta mirada, nos centraremos en un tercer momento, en los aportes ontológicos que han ofrecido algunos pensadores latinoamericanos considerados como claros ejemplos en la búsqueda de un encuentro investigativo intercultural. Sin embargo, no es posible finalizar este capítulo sin considerar el marco propio de la filosofía intercultural cuyo apartado finiquitará lo que consideramos es la primera parte capitular.

\subsection{En búsqueda del ser}

Desde la antigüedad con Parménides y Aristóteles la pregunta por el ser ha sido, si no la cuestión fundamental sobre la cual se ha construido la filosofía, por lo menos sí uno de los cuestionamientos fundacionales de la razón y la existencia. Si bien es cierto que la pregunta por el ser ha existido desde antaño, también es verdad que ha sido relegada al olvido, según Heidegger, desde los mismos griegos y hasta nuestros días; fue hasta el siglo XX cuando el filósofo alemán Martín Heidegger, ha vuelto a poner sobre la mesa, de forma renovada, la pregunta por el ser, porque ahora la comprende temporalmente: ser y tiempo van a una y según el filósofo- solo se puede comprender cada uno de estos conceptos en relación con el otro. El ser se devela en los entes que se abren históricamente dentro del tiempo y éste, el tiempo, apaña existencialmente el sentido del ser.

Entonces la ontología para Heidegger posee un carácter temporal dado que el ser se mantiene vigente en el tiempo, dicha disciplina toma distancia de la metafísica ya que ésta se quedará 
finalmente buscando comprender los entes en cuanto a tales, sin mirar al ser que es el fundamento de aquellos.

La metafísica es fatalidad en el sentido estricto de esta palabra, en el único sentido en el que aquí nos referimos: en ella, como rasgo fundamental de la historia acontecida de la Europa occidental, deja las cosas del hombre suspendidas en medio del ente, sin que el ser del ente pueda jamás ser experienciado, interrogado y ensamblado en su verdad como el pliegue de ambos (Heidegger, 2001:56).

A su vez, Heidegger refiere a la diferencia ontológica hacia la que apunta la pregunta por el sentido del ser. Al respecto, el ente para Heidegger es sinónimo de técnica, es decir de un trabajo consumado que no trasciende hacia la ontología: «el nombre "la técnica" está entendido aquí de un modo tan esencial, que en su significado coincide con el rótulo: la Metafísica consumada» (Heidegger, 2001: 58). Esta consumación señalada por el autor acaece en una imagen limitada de la metafísica, frente a la búsqueda del sentido por la pregunta por el ser, de ahí que para Heidegger no es responsabilidad de la metafísica pensar el ser porque «la metafísica representa a lo ente en su ser y, por ende, también piensa al ser de lo ente. Pero no piensa el ser como tal, no piensa la diferencia entre ambos. La metafísica no pregunta por la verdad del ser mismo» (Heidegger, 2007b: 266).

Como el ente está enfocado hacía la metafísica según el pensador germano, es pues la ontología el camino que puede develar el sentido del ser; en este camino se debe desarrollar el pensamiento ontológico, es cual es clave en la búsqueda por auscultar el ser de manera que «el pensar está vinculado al advenimiento del ser, y en cuanto advenimiento está vinculado al ser» (Heidegger, 2007b: 296). Se enfrenta, por tanto, a la lucha por la superación del olvido del ser que solo se da al pensar en esencia ontológica, no por el ente del ser sino por la posibilidad del ser humano en tanto ente, que piensa ontológicamente y pregunta por el ser.

En ser y tiempo (1963), el pensador alemán deja en claro que la finalidad de esta empresa reside en dar respuesta a la pregunta primera de la filosofía y no a su Dasein, es decir, 
adentrarse en la pregunta por la existencia misma y no por el ser que piensa esta existencia: el ser humano; en este sentido, su propuesta no es, de ninguna manera, antropológica, sino ontológica; Porque si bien la primera parte de Ser y tiempo estuvo dedicada al Dasein como analítica existenciaria, la finalidad se centraba no en el ser humano, sino en el ser en su totalidad. Pero, dada la situación, la pregunta ¿qué pasa con el ser?, denota la necesidad de una ontología resignificada, en la que se apueste por un «esfuerzo de llevar el ser a la palabra, y concretamente mediante el recorrido por la pregunta ¿qué es del ser? (no solo del ente como tal)» (Heidegger, 2003: 45). La pregunta por el ser para Heidegger tiene un componente histórico y a su vez existencial, puesto que como entes somos los únicos que nos podemos preguntar por el ser del ente.

Nuestro preguntar la pregunta metafísica fundamental es histórico porque inaugura el acontecer de la ex-sistencia del hombre en sus referencias esenciales, es decir, sus referencias con el ente como tal en su totalidad, abriendo así posibilidades no planteadas y futuros, con lo que al mismo tiempo vuelve a vincular la ex-sistencia del hombre en su origen pretérito, endureciendo y dificultándolo de este modo en el presente (Heidegger, 2003: 48).

Así, la pregunta por el ser y la manera en que el ser está en el mundo -señala Heidegger-, también enuncia una dificultad en el lenguaje que se construye a través de la búsqueda por el sentido del ser. El ser en relación con los entes se hace comprensible en la medida que determinamos cada cosa existente o no existente a través de diversas características, por ejemplo, que el agua es transparente o el cielo sea azul, hacen parte de las situaciones factibles de distinguir; pero cuando nos referimos a este ser que le otorga las posibilidades de existencia y las características no solo al agua y al cielo sino a todo cuanto vive, la respuesta empieza a difuminarse.

Una mirada a la etimología de «ser» muestra que, entre los griegos, esta palabra hablaba de estabilidad en dos sentidos: primero, en el sentido de physis, es decir lo que está surgiendo; segundo, en el sentido de estable, lo permanente, lo que perdura, ousía (Heidegger, 2003: 65). El ser: lo que se manifiesta desde su estabilidad. Como 
verbo, en infinitivo, no da idea de una sustancia, y por eso más bien da la idea de vapor que se esfuma; pero sustantivado, anteponiendo un artículo, el ser, da la idea de algo más estable que, de todas formas, está manifestándose, y así se le comprende como [lo que] es (Heidegger, 2003: 69 citado en Cepeda 2017).

En un esfuerzo por asir el ser y a raíz de la influencia que surtió efecto con las lecturas de Heráclito, Heidegger aproxima el ser al devenir a partir de los cuales manifiesta la existencia de una estrecha relación entre ambos conceptos, en términos de ser como devenir; Heidegger va a señalar que el ser es lo que aparece y se devela en los entes, pero también, entre todos, nosotros somos ese ente que puede pensar el ser en clave ontológica, pensar y apalabrar lo que el ser es. Dicha comprensión del ser «sigue sosteniendo y dominando hasta hoy todas nuestras referencias al ser del ente en su totalidad, al devenir, a la apariencia, al pensar y al deber ser» (Heidegger, 2003: 182).

Heidegger advierte la necesidad de preguntar por la verdad de lo que existe en tanto que es en la realidad; sin embargo, se ve enfrentado no al ente mismo que es percibido sino al trasfondo que constituye este mismo ente, lo que lo hace ser no solo con las características específicas que lo determinan, sino en tanto manifestación en el mundo. Al respecto, traza el camino hacia la búsqueda del ser que permite la existencia misma representada en los entes que percibimos porque, en este ser, encontraría la verdad.

La pregunta por el ser deviene ahora pregunta por la verdad del ser. La esencia de la verdad es ahora interrogada desde el esenciarse del ser, concibiéndola como el claro de lo que se oculta y con ello como perteneciente a la esencia del ser mismo. La pregunta por la verdad "del" ser se desoculta como la pregunta por el ser "de" la verdad (...). Ahora el preguntar por el ser ya no piensa a partir del ente, sino que ha sido, como pensar del ser, forzado a través del ser mismo (Heidegger, 2006c: 342).

En la breve frase de Heidegger el ser es, el ente no es, explicita el ser como verdad universal que se apalabra desde el ente pero que deviene como ocultamiento y desocultamiento del ser que decanta en verdad. Por tanto, el ser no está solamente en la exterioridad, sino que habita, 
por ejemplo, en la posibilidad de pensarse, de sentirse, de ocultarse. De ahí que Heidegger exprese incluso en verso al ser, en un intento por perfilar el sendero ontológico al que se empezaba a aproximar:

\author{
resolución como ser \\ ser y verdad \\ verdad y ser-ahí \\ ser-ahí e historia \\ historia y de-cisión \\ de-cisión y ser \\ ser y a-bismo \\ a-bismo y lo más elevado \\ lo más elevado y lo próximo (Heidegger, 2011: 64).
}

Esta forma diferente de apalabrar el ser, encarna una gran influencia para la ontología en general, logrando también cierta primacía en la ontología latinoamericana, en especial, a través de filósofos como Rodolfo Kusch, Ernildo Stein y Juan Cepeda H, por mencionar algunos. En el caso de Fornet-Betancourt, la búsqueda por una respuesta a la pregunta por el ser, es retomada en el artículo "La filosofía intercultural en América Latina. Apuntes para su historia" donde precisamente destaca, una nueva perspectiva ontológica de carácter intercultural en relación con el filósofo colombiano Juan Cepeda $\mathrm{H}$ y su sentipensar ontológico, al cual refiere en los siguientes términos:

Juan Cepeda H., de la Universidad Santo Tomás, quien ha investigado la ontología en América Latina, desde la interculturalidad y la analogía a la luz de los aportes que ofrece la filosofía del pensador argentino Rodolfo Kusch. Su apuesta de sentipensar ontológico responde precisamente a estas inquietudes que evidencian la diversidad cultural latinoamericana (Fornet-Betancourt, sf: 15).

La influencia de Martín Heidegger, en este caso, genera aportes a la filosofía universal desde la participación sentipensante, ontológica e intercultural de América Latina, porque el ser es 
en todo lugar, en todo momento, para todos, diferente y mismo, trasciende las fronteras, los pensamientos, la totalidad existencial, es eventual y es permanente, verdad oculta y manifiesta:

El evento como el ser.

El ser como la verdad.

Sólo el ser es (Heidegger, 2011: 172).

El ser es.

Esto, el único dicho (Heidegger, 2011: 173).

\subsection{Ontología latinoamericana}

La ontología, como disciplina filosófica que se pregunta por el sentido del ser en cuanto ser, ha sido considerada desde la antigüedad hasta nuestros días bajo denominaciones tales como filosofía primera o metafísica. La pregunta por el ser no puede concebirse separada del pensar fundamental de la filosofía, pero la filosofía tampoco debe permitirse evitar pensar el ser, el principio, el origen; por lo menos son los argumentos que, con Heidegger, buscamos advertir:

El problema del ser surge en la filosofía y no deja de fluir como problema radical que aporta un fundamento al pensar, aun a pesar de épocas en que se considere necio todo recurso a los fundamentos; al contrario, en el caso de Heidegger, el del sentido del ser es el problema fundamental de la filosofía desde sus orígenes hasta la actualidad (Cepeda H., 2017b:19).

Porque es necesario un barrido histórico que conduzca hacia los aportes actuales de la ontología en América Latina es que podemos prever que, desde los presocráticos, las preguntas en torno a la cosmovisión, al origen de todo lo que existe, estuvieron impregnadas por un lenguaje ontológico, pues en toda la investigación desarrollada por el principio originario de todo lo material subyacía la pregunta por el ser, a saber: ¿qué es lo que es y qué 
es lo que no es? cuyo rasgo particular al preguntar, analizar y reflexionar de los presocráticos, ya comenzaba a plantear el desarrollo de enunciados ontológicos basados en la observación del mundo y la realidad a través del asombro.

Por medio de la exploración y el contacto continuo con los fenómenos naturales se fueron estructurando teorías que pretendían ir más allá de las explicaciones míticas sobre la configuración y el origen de todo. Con ello, la filosofía presocrática, inició una investigación crítica de la naturaleza, que incluyó el registro de sucesos, así como las cuestiones más cercanas a los hechos particulares de la naturaleza, en lo que supone un nuevo acercamiento al ser, desde la sensibilidad natural en reciprocidad con el pensamiento científico que hasta ese momento empezaba a gestarse. En este sentido, se puede decir que:

Los fragmentos de los presocráticos, e inclusive los clásicos de la literatura y no solamente los grandes tratados de los filósofos, muestran que la sintaxis y la semántica griegas se construyeron con un sentido ontológico. Y tenía que ser así.El asombro griego, que llevó a que fuera precisamente allí donde se encunara la filosofía, fue un asombro por lo que es, por lo que devenía en el ser: ¿qué es y qué no es?, podría ser la pregunta implícita de todo el pensar griego; de ahí que uno de los textos arcaicos, clásicos y primeros, de la filosofía, el llamado [poema de Parménides] venga a expresar que el ser es y el no ser no es (Cepeda H, 2013a: 97).

Los presocráticos construyeron teorías sobre el origen de las cosas, sobre el movimiento, el cambio y los hechos presentes en la naturaleza. Sin embargo, precisamente, fue uno de los presocráticos, Parménides (541-? a.C.) quien se refirió al ser como algo que no puede ser percibido por los sentidos, pero que siempre está presente. Para Parménides el ser es uno, inmutable, infinito y eterno.

Particularmente, la polémica entre Heráclito y Parménides se desarrolla a partir del tema del cambio, un concepto problematizado en la primera época de la filosofía griega, basado en explicar la posibilidad y la manera en que los objetos se transforman. Heráclito entiende el cambio como un elemento presente en cada instante y en cada cosa. Nada permanece, afirma, 
nada se detiene: todo se encuentra envuelto en un proceso de transformación continuo y eterno. Ante esta posición, Parménides plantea que las cosas nunca cambian, que todo permanece estable. El cambio, para Parménides, es una ilusión ofrecida por los sentidos. De esta manera, como lo explica Gilson en la obra El ser y los filósofos (2005) Parménides, desde un lenguaje propiamente ontológico, formula el Ser como el principio constitutivo del universo: un ser que ante las eventuales transformaciones de los entes permanece estático e inmóvil, puesto que sus características principales son la eternidad y la incorruptibilidad. No por esto, Heráclito deja de tener importancia, al contrario, aunque el ser en sí mismo no cambie, es el cambio una de sus características en la vida de los entes, por lo que el movimiento y la quietud hacen parte de su propia esencia: cambia en la medida que sigue siendo el mismo, es decir, que no se aparta de sus inherentes posibilidades.

Respecto a la filosofía platónica y su concepción de un mundo sensible adscrito a los hombres y a la materia no humana, podemos también percibir un trasfondo relacionado con el mundo de las ideas, en especial, porque no son fácilmente alcanzables en el mundo sensible pues su acceso está restringido al campo de la razón; sin embargo, queda la sensación de que en la realidad vital de los sentidos no es posible asir el ser, ya que se encuentra condenada a las sombras, la muerte, la materialidad, la modificación y lo insignificante, mientras la razón logra alcanzar la idea que, como el ser de Parménides, es algo permanentemente eterno e inmutable.

El pensamiento de Aristóteles, por su parte, va a unir la ontología y la construcción sobre la pregunta por el ser con la ética; de esta manera, el ser solo se puede entender a través de la forma en que se expresa en el lenguaje y a través de una perspectiva múltiple. Precisamente Aristóteles es quien elabora la pregunta que hoy nos convoca, en su filosofía primera se pregunta por el ser: ¿Qué es el ser?, su respuesta no va a reducir la complejidad del ser, sino que, podríamos decir, por primera vez el ser responde a la multiplicidad en tanto puede ser nombrado de diferentes maneras, denominado a partir de diversos términos. En la obra El ser y los filósofos (2005), Gilson explica cómo Aristóteles plantea una ontología lingüística que se asocia a la acción racional comunicativa, a la forma en que el hombre actúa y se desempeña 
conforme a una serie de principios que lo llevan a una acción prudente, sabia y libre. Por tanto, en Aristóteles la pregunta por el ser se liga también a la pregunta por el actuar y el quehacer en el mundo, por el papel que debe desempeñar el ser humano y los lineamientos éticos que orientan la conducta.

En la edad Media, la pregunta por el ser es referenciada por filósofos y teólogos como santo Tomás de Aquino (1225-1274 d.C.), Juan Duns Escoto (810-877 d.C.) y Francisco Suárez (1548-1617 d.C.) quienes, a grandes rasgos, al preguntarse por el ser, orientaban este cuestionamiento en términos teocéntricos debido a que su gran referente era Dios como el ser creador de todos los seres. A partir de las Confesiones de Santo Tomás de Aquino y La Ciudad de Dios de San Agustín queda establecida tanto en la teología como en la filosofía occidental la noción del "libre albedrío" como uno de los componentes de la existencia humana. Para San Agustín, el libre albedrío es el «poder que tiene el individuo de escoger decisivamente en el curso de su vida con los varios fines y acciones que de ahí se derivan» (Burgos G y Martín M, 2015: 45). En este sentido, ser es ser libre por la voluntad de Dios, pero también es ser uno en bondad, anclados al amor. En efecto, este libre albedrío es un don divino, una gracia concedida al ser humano, mientras que Dios determina el límite del origen y del fin de toda existencia.

En la modernidad, entre el nacimiento de diversas corrientes filosóficas como el idealismo alemán, el empirismo inglés y la filosofía analítica, la pregunta por el ser iba perdiendo el lugar central que tradicionalmente ha mantenido para la filosofía, pues la atención intelectual y académica del momento estaban fijadas en las teorías del conocimiento, la fenomenología y las distintas posturas del racionalismo. Por ejemplo, Descartes identifica la existencia con la esencia, y plantea que la única diferencia que existe entre las dos es de razón. El problema para Descartes es que el hombre no tiene una idea clara y distinta de la existencia, por lo cual no es posible comprenderla. Spinoza, por su parte, considera que la existencia es la esencia considerada en sí misma, es decir, fuera de Dios. 
Kant indica que el ser no es un predicado real, y que ninguna esencia puede implicar su existencia, de tal manera que no puede haber una similitud entre la esencia y la existencia. De esta manera, el idealismo crítico de Kant postula que es la existencia, más no la esencia, la que puede impresionar o afectar a la sensibilidad. Hegel plantea que el ser es un concepto limitado, abstracto, que no tiene ninguna representación en la medida en que no es objeto de la intuición intelectual. Por lo tanto, el ser es nada, y es idéntico al no-ser: algo indeterminado que solo existe en medio de un constante devenir, es decir, que pasa sin mucho sentido.

Finalmente, para Nietzsche, en el devenir también se encuentra impreso el carácter del ser, un ser de voluntad que en últimas desemboca en un ser del ente. Por tanto, el ser para Nietzsche no es algo que vaya más allá de un término que se ha establecido y desarrollado a través de la historia, como un pretexto para hablar de realidades inexistentes que se proyectan más allá de la realidad, es un espacio incomprensible y abstracto, similares al mundo de las ideas de Platón. El ser, por tanto, se contrapone a una evidente facticidad de los acontecimientos vitales, al cambio y a la transformación constante que pregonaba Heráclito en los comienzos de la filosofía.

Pero es hasta el siglo XX cuando el filósofo alemán Martin Heidegger de nuevo retoma la pregunta aristotélica por el ser y revitaliza aquel cuestionamiento. El filósofo germano señala paradójicamente que se ha perdido de vista desde la antigüedad la pregunta de la filosofía primera que señaló el mismo Aristóteles e inicia el camino hacia una ontología que transformaría los márgenes doctrinales de la filosofía contemporánea.

En particular, como lo explica Grondin en su obra Introducción a la metafísica (2006), para Heidegger la ontología, comprendida como una pregunta por el ente en su conjunto, oculta al ser precisamente en lo que tiene de inexplicable y de oculto. Básicamente, es aquello que permanece oculto lo que constituye la experiencia que tienen los hombres del ser, aquello por lo que se es, pero también aquello sobre lo cual no se puede decidir. Por tanto, concluye Heidegger, el hombre solo puede experimentar el ser a través del tiempo. El pensamiento bastante riguroso de Heidegger lleva a hacer una fina distinción entre ente y ser, a la que él 
llama diferencia ontológica. No se pueden confundir estos dos conceptos: mientras el primero alude a las cosas mismas, ahí ante los ojos, lo óntico, el ser alude al fundamento de todo lo que es, lo ontológico; según Heidegger, a los estudios sobre el ente se les puede comprender como metafísicos, en tanto que solamente lo que se refiere al ser, en cuanto que ser, se le puede denominar ontológico. Y sobre esta diferencia proyecta toda su investigación, insistiendo en la comprensión del sentido de la pregunta que interroga por el ser.

Este análisis que plantea Heidegger sobre el ser, desde una postura llena de incertidumbre que rescata lo oscuro, desconcertante e incógnito que compone al ser, deriva en las posturas existencialistas de la segunda mitad del siglo XX. Para el existencialismo, aquel libre albedrío del que se hablaba en la edad media, al estar sujeto a una delimitación divina previa, no representaba el sentido que explicara el papel del hombre en el mundo. De esta manera, en el existencialismo no hay tal predisposición divina y el ser humano es dejado solo por completo, de tal manera que debe tomar y afrontar sus propias elecciones.

En el existencialismo, entonces, se considera que «la existencia precede a la esencia» (Sartre, J, 2004: 27). Con esto, es posible transmitir el mensaje de que no hay un destino o un camino predeterminado para el individuo, ya que él mismo lo construye individualmente porque «el hombre empieza por existir, se encuentra, surge en el mundo, y [...] después se define. [...] Sólo será después, y será tal como se haya hecho. Así pues, no hay naturaleza humana [...]» (Sartre, 2004: 31). Es decir, el individuo es instaurado como responsable de su propia vida, la cual puede moldear a partir de procesos de elección; lo que va a desencadenar, como consecuencia, el concepto de angustia dentro de esta corriente de pensamiento:

[...] el hombre es angustia. Esto significa que el hombre que se compromete y que se da cuenta de que es no sólo el que elige ser, sino también un legislador, que al mismo tiempo que a sí mismo elige a toda la humanidad, no podría escapar al sentimiento de su total y profunda responsabilidad (Sartre J, 2004: 35, 36). 
La angustia es una eterna compañera de la existencia humana, pero también es el resultado del reconocimiento de la gran responsabilidad que ha caído sobre los hombros de los mortales, ya no preestablecidos por un designio divino.

Como se puede apreciar, la ontología y la pregunta por el ser han estado ligadas a lo largo de la historia con diferentes temas, como el descubrimiento de la naturaleza y la composición de los objetos, las ideas, la sustancia primera, la ética, las virtudes, el papel del hombre en el mundo, el libre albedrío, la voluntad divina y la existencia. Es indudable que la recepción de todas estas influencias filosóficas, especialmente con Heidegger y su deconstrucción histórica sobre la ontología, han enriquecido de manera notable, por lo menos desde el cuarto decenio del siglo XX, el desarrollo de la ontología en América Latina.

Será también a partir de esta época que empiezan a surgir valiosos aportes desde la ontología latinoamericana, con el Tratado de Metafísica (1929) de José Vasconcelos, la Metafísica natural, estabilizada y problemática (1963) de Juan David García Bacca, o el tratado de metafísica Teoría de la habencia (1982) de Agustín Basave, así como la recepción crítica de la ontología heideggeriana que hiciera el filósofo argentino Rodolfo Kusch, a través de obras como La seducción de la Barbarie: análisis herético de un continente mestizo (1953), América Profunda (1962) y El pensamiento indígena y popular en América (1973), entre otras, en las que va mostrando desde una manera más propia la concepción de ser en el pensamiento indígena y popular latinoamericano, cuya categoría fundamental más que el ser radica en el estar.

Ahora bien, es importante observar cómo en Latinoamérica el desarrollo por la pregunta ontológica sobre el ser, su devenir y su transformación, se asocia al proceso de descolonización, que desde la filosofía latinoamericana ha concebido un proceso integral que implica la trasformación continua de las jerarquías epistemológicas, de las relaciones de poder, de los procesos de convivencia, además de las estructuras económicas, sociales y espirituales desde las cuales han sido construidas las comunidades. Por lo tanto, la 
perspectiva de la descolonización permite visibilizar las sociedades que han sido vulneradas a través de los procesos de colonización, para promover alternativas de transformación social.

La descolonización implica, ante todo, el análisis del trasfondo en el control de conocimiento como medio para generar subjetividades críticas que comprendan la necesidad de otras miradas aunque implique contraposición con la mirada generalizada, así como viabilizar la participación y la solidaridad al interior de las comunidades, con la finalidad no solo de reivindicar la cultura y la procesos de resistencia, sino también de establecer nuevas organizaciones sociales que se asocien a modelos alternativos de conformación comunitaria. Porque la filosofía latinoamericana no busca repetir las formas de conocimiento impuestas sino mostrar que desde la diferencia también es posible integrar las diversas experiencias culturales generadas antes y después de los procesos de colonización:

Este mestizaje, base de la utopía, se ha realizado en la América Latina a partir de la actitud del conquistador y colonizador de la región, del español que traía ya dentro de sí el mestizaje racial y cultural que la conquista y dominio moro impusieron a la Península Ibérica a lo largo de ocho siglos (...) Así, a la raza y cultura primitivas de este Continente se sumó la de los conquistadores y colonizadores y a ellas las raza y cultura africana de hombres arrancados de su raíz para satisfacer la ambición del conquistador ibero. A estas mezclas se sumaron las de las razas de culturas de otras regiones de la tierra (Zea L, 1993: 369).

Este mestizaje intercultural, explica Dussel en su obra De la fraternidad a la solidaridad; hacia una política de la liberación (2006), implica trascender una visión verticalista y exclusionista, en búsqueda de una perspectiva horizontal e incluyente, que reconozca el valor de las diferentes manifestaciones sociales y las diversas maneras de crear comunidades. De esta forma y como parte de la filosofía latinoamericana, se abre paso a una mirada sobre el estudio del ser y su cultura como un elemento liberador, que le brinda las posibilidades a los pueblos para resistir y establecer sus visiones particulares sobre el mundo y sus formas de generar relaciones con el entorno: «La cultura es por esencia liberadora de los obstáculos que impiden a los hombres y pueblos realizar sus proyectos» (Zea L, 1990: 47). 
En este breve recorrido cuyo inicio fue dado por el asombro natural de los presocráticos hasta intentar alcanzar cierto desarrollo de una ontología latinoamericana que se encuentra definitivamente asociado a los procesos de reivindicación social y cultural frente al conocimiento mayoritario que nos ha sido entregado desde occidente, es importante reconocer al filósofo colombiano Juan Cepeda $\mathrm{H}$, quien desde un horizonte latinoamericano se ha dedicado a la ontología y a la pregunta por el ser. En su tesis filosófica defiende el Sentipensar ontológico (2017 a), obra fundamental que no solo apertura el panorama desde una ontología intercultural en América Latina, sino que además rescata el valor de la filosofía intercultural como camino que surca constantemente entre la diversidad, el devenir rítmico y el destino mandálico como acontecer del ser.

\subsection{Ontología Intercultural}

Proponer desde los márgenes periféricos que, incluso, hasta la propia filosofía ha generado al rechazar ciertas corrientes del pensamiento lejanas a la lógica europea, una ontología intercultural que enmarca en sí mismo un horizonte de significación alterno a la tradición filosófica occidental parecería algo inadecuado. Estermann, en Filosofía Andina (1998), después de haber convivido con distintas comunidades indígenas en Suramérica, ha evidenciado que, aunque no es evidente la pregunta específica por el ser en dichas comunidades, también es verdad que asumen una construcción distinta del horizonte ontológico, basado en el concepto que el filósofo suizo llamará "relacionalidad" desde el que elabora una lógicidad relacional distinta a la común, al comprender que no es absurdo pensar en la posibilidad de hallar un sustrato de ontologías indígenas en América Latina y que, por el contrario, es necesario resaltar las sapiencias y los valores que desde antaño han existido en culturas como la nuestra.

Y quizás quien mejor abandera la propuesta de la ontología intercultural, cimentada desde el hedor, en el estar siendo, es Rodolfo Kusch. Aunque la intención de Kusch era rescatar el 
pensamiento indígena como pensamiento filosófico valido y legítimo, terminó mostrando esbozos de una ontología latinoamericana, que sería trabajada como fractura epistemológica de América Latina con Occidente; esto a su vez constituye un punto fundamental en el compromiso intelectual de Kusch por rescatar las identidades perdidas y sub-valoradas de nuestra identidad cultural, pues el ser latinoamericano no se hace a priori por el simple hecho de nacer en América Latina, sino que se es un sujeto latinoamericano por despertar y estar siendo con el paisaje inanemente natural que constituye una realidad auténtica.

La noción de "hedor" es fundamental para comprender el pensamiento de Kusch, de ahí que signifique la estancia, el estar que caracteriza la real esencia de lo que somos en un lugar y tiempo específicos, es, a su vez, la animalidad que intentamos ocultar al anteponer el ser en tanto pulcritud, desligando al sujeto de su identidad. Entonces el hedor representa lo inocultable, lo que hiede a telúrico, pero también lo que expresa el miedo y el horror de lo que somos cuando no somos conscientes de nuestro estar. Así lo señala Mignolo:

Seriamos más proclives a aceptar la ubicación de las herencias del pensamiento indígena y las huellas de sus transformaciones desde la colonia hasta nuestros días. Pero habría que reflexionar más, sin embargo, no solo en lo que Kusch trata de rescatar, sino como propone hacerlo: el proyecto no se "debe solo al deseo de exhumarlo científicamente, sino a la necesidad de rescatar un estilo de pensar que, según creo, se da en el fondo de América y que mantiene cierta vigencia en las poblaciones criollas" (Mignolo, 1995: 31).

Este estilo del pensar que retoma Mignolo de la filosofía kuscheana denota un sustrato desde el estar arrojados en la tierra, en la geografía propiamente latinoamericana a partir de la cual es posible experimentar una relación telúrica y existencial, es decir, entrañablemente ontológica; precisamente para Kusch si hay una cultura que puede darle trascendencia al concepto de ontología es la latinoamericana, porque reúne tanto la filiación geocultural viva pese a la colonización como porque la mentalidad, el paisaje y el hedor se manifiestan como formas naturales que contradicen el ser occidental a favor del sentir natural. 
La necesidad de estructurar la vida a imagen y semejanza de la cultura europea desde la colonización hasta la actualidad ha sido una circunstancia innegable en América Latina, en especial para los indígenas que ancestralmente han ocupado su geografía, prolongado las prácticas y pervivido en la genética cultural de los territorios; a raíz de esta situación ha surgido el problema de la negación de una identidad cultural porque no es aparentemente clara la existencia de un pensamiento propio sino, al contrario, la constante discordia entre la cultura occidental europea y la cultura aborigen inmersas en un mismo espacio-tiempo latinoamericano. En este sentido, la descolonización no se puede limitar al desarrollo de movimientos sociales, ya que los procesos de colonización que se han establecido desde Occidente en los pueblos de América Latina no dependen únicamente de la presencia de administradores coloniales, sino de un conjunto de formas de vida, de modos de relación y de construcción social que imperan por su establecimiento en las mentalidades e impiden a comunidades enteras desarrollar sus propias cosmovisiones desde una tradición ancestral.

Estas formas de vida son rescatadas precisamente por el filósofo Juan David García Bacca, quien desarrolla un pensamiento a partir del enfoque en los flujos racionales de cada época, pero también la cultura y la forma en que se conciben nuevas relaciones entre el hombre y el espacio que habita. La historia, por tanto, mantiene un constante pulso de cambio, del cual se desprende un conjunto histórico-vital que comprende al ser permeado por el papel determinante de las relaciones con otras culturas, cuyos intercambios son generados de manera natural, al tiempo que actualizan y transforman alser desde las diversas miradas que se van generando.

Por lo tanto, como lo explica Kusch en la obra Geocultura del hombre americano (1976), los procesos de reivindicación de las culturas y tradiciones de los pueblos implican, ante todo, el control del conocimiento como medio para generar nuevas subjetividades que apoyen el desarrollo de concepciones específicas del mundo, a partir de elementos como la participación y la solidaridad al interior de las comunidades, con la finalidad no solo de 
reivindicar la cultura mediante procesos de resistencia, sino también de establecer nuevas organizaciones sociales que se asocien a modelos alternativos de conformación comunitaria.

Son precisamente estas reivindicaciones las que permiten comprender cómo la lucha por la identidad de los pueblos se asocia a un proceso multidimensional adscrito a la transformación continua de las jerarquías epistemológicas, de las relaciones de poder, de los procesos de convivencia, de las estructuras económicas, sociales y espirituales desde las cuales se conforman las comunidades que responden, finalmente, a un proceso particular de construcción del ser. Por lo tanto, la reivindicación apertura el horizonte a las sociedades que han sido vulneradas a través de la colonización, promoviendo su participación en alternativas de cambio social que dependen, en gran medida, de la manera en la cual logren reconocer, comprender y enfrentar las situaciones adversas que han padecido.

En esta misma línea de pensamiento, el pensador Agustín Basave en la obra Posibilidad y límites de una filosofía latinoamericana (1979), rechaza la idea según la cual la filosofía en América Latina inicia con el denominado descubrimiento, en 1942; significa, entonces, que no existe ninguna diferencia entre la filosofía de occidente y la filosofía latinoamericana, ya que en el "nuevo territorio conquistado" únicamente existían cosmovisiones que no estaban apoyadas por ningún fundamento objetivo racional, según esta apreciación. De tal forma que la filosofía en Latinoamérica sería la misma filosofía de occidente, que se sembró en el territorio como una planta que comienza a crecer y a dar nuevos frutos; sin embargo, las luchas y las reivindicaciones demuestran que las culturas indígenas originariamente entrañan una comprensión particular del ser, ligada a su relación con el territorio, a un relacionamiento espiritual que vincula a las nuevas generaciones con los antepasados, a través de un vínculo inmerso en la identidad de la comunidad.

Indudablemente, habiendo asumido de Kusch el horizonte de comprensión intercultural, Juan Cepeda H. propone desde su obra Sentipensar ontológico (2017 a), una riqueza inmanente enraizada en los saberes ancestrales indígenas, en las sabidurías rítmicas afro, en las riquezas conceptuales campesinas, en las tradiciones populares implícitas en los discursos "urbanos" 
y en la tradición filosófica occidental. Tanto en los encuentros académicos como en la producción bibliográfica del filósofo colombiano, es evidente una propuesta intercultural de ontología latinoamericana, lo que posibilita ahondar en este proyecto de investigación que busca comprender precisamente los fundamentos ontológicos de la filosofía intercultural.

Como lo explica Cepeda en su escrito “Ontología indígena, aproximación filosófica a saberes precolombinos que posibilitan una ontología latinoamericana" (2012), para establecer un diálogo filosófico con las comunidades indígenas latinoamericanas, es preciso liberarnos primero de los horizontes de comprensión que Occidente ha establecido a través de la historia de la filosofía como imposición de un conjunto de sesgos que no solo limitan sino que también afectan el estudio de las conocimientos que los indígenas han desarrollado sobre sí mismos y sobre su entorno en América Latina. En particular, Cepeda en el artículo "¿Cómo surge el ser?" (2013a) critica esa idea que se ha fomentado durante siglos, según la cual la filosofía es una ciencia de la razón y que, por lo tanto, la comprensión de la filosofía de una sociedad o de una comunidad particular implica analizar los procesos racionales mediante los cuales se construye la realidad. En medio de este proceso a través del cual se le da privilegio a la razón por encima de los sentimientos y los aspectos sensoriales, son generados numerosos prejuicios que coartan todo tipo de investigación con miras a confrontar lo real.

En la tarea de comprender la cultura, el pensamiento y la filosofía de las comunidades indígenas latinoamericanas, es necesario «escucharles tratando sinceramente de liberarnos de los condicionamientos mentales que se han generado de antemano» (Cepeda H, 2012: 20). Al respecto, por ejemplo, la relación que construyen las comunidades indígenas con el territorio se establece a partir de la construcción de un sentido simbólico, determinado por un conjunto de elementos como el entorno, representado en términos del espacio, el medio ambiente, las tradiciones, las creencias, los miedos y la espiritualidad trascendente, que develan una permanente relación de correspondencia e interdependencia entre las comunidades indígenas y el territorio. 
Según José Vasconcelos, tanto el individuo como la comunidad se construyen a sí mismos a partir de sus múltiples formas de ser uno con el entorno, adscribiendo en su identidad tanto rasgos característicos como el compendio de elementos que determinan la visión propia sobre el ser humano. Por lo tanto, comprender el desarrollo del pensamiento latinoamericano en las culturas indígenas implica comprender sus horizontes de significación, ir más allá de la razón y la objetivación, para adentrarse en las sensaciones y las emociones a través de las cuales se construyen nuevas miradas del ser fundamentales en el encuentro intercultural:

La idea de que el diálogo filosófico intercultural debe ser un diálogo que supere los prejuicios que todavía se mantienen frente a otras formas de pensar y de conocer que supuestamente no son «racionales» porque son, por ejemplo, «mitológicas»o «religiosas», excluyéndoselas así de la filosofía (Fornet-Betancourt, 2007: 26).

En síntesis, la ontología de la interculturalidad se preocupa por reivindicar las formas y las experiencias filosóficas alternativas descentradas. La filosofía intercultural promueve el desarrollo de un pensamiento que se manifiesta desde distintos lugares, a través, precisamente, del sumario de relaciones e intercambios anexos a las expresiones de una vida que se construye a sí misma de manera continua en contextos determinados, consolidando en algunos de ellos, visiones alternativas del ser ligadas fuertemente a la naturaleza y la identidad $^{1}$, como es el caso de los pueblos originarios de nuestra América.

\subsection{Filosofía intercultural}

La filosofía intercultural se ha convertido en una de las corrientes más influyentes surgidas al interior de la Filosofía Latinoamericana, a partir de aspectos ético-políticos y epistemológicos que luchan por legitimar horizontes de nuevas racionalidades, de nuevas transfiguraciones y de otros saberes, donde se contrastan posturas clásicas de la filosofía en

\footnotetext{
${ }^{1}$ Entiéndase aquí los conceptos de naturaleza e identidad desde perspectivas cosmogónicas propias de las comunidades étnicas en relación con sus territorios, sus saberes y sus horizontes de significancia, a su vez, construidos alrededor de la historia, las costumbres y las herencias que les pertenece.
} 
una propuesta alterna de la realidad política y social mayoritaria, así como de las maneras de conocer.

En la actualidad, el representante más importante de la filosofía intercultural es Raúl FornetBetancourt, quien concibe su proyecto filosófico no como concepto dual, externo y homogéneo, sino como transfiguración dialéctica e inter-dependiente, inserta en la constelación filosófica que encarna los saberes otros, la alteridad y la alterna forma de acercarnos a una América Latina. Entre sus obras más importantes se encuentran Transformación intercultural de la filosofía (2001), Crítica intercultural de la filosofía latinoamericana actual (2004), Modelos de teoría liberadora de la historia de la filosofía europea (2008), Mujer y filosofía en el pensamiento iberoamericano: momentos de una relación difícil (2009) y la introducción a la obra Aproximaciones ontológicas lo latinoamericano I (2013) entre otras.

En particular, la filosofía de Fornet-Betancourt concibe dentro de su propuesta la capacidad de autocrítica respecto a la propia filosofía latinoamericana, es más, reconoce que solamente a partir de la reflexión sobre los procesos históricos es posible generar un verdadero diálogo en el presente. Comprender la historia de la filosofía latinoamericana, por tanto, implica reconocer también sus articulaciones, la forma en que las costumbres ancestrales se mantienen en muchas de las prácticas actuales, así como la forma en que las sociedades identidades específicas. Este proceso de comprensión, explica Fornet-Betancourt en la obra Crítica intercultural de la filosofía latinoamericana actual (2004), debe establecer en la actualidad la dinámica de una de las tareas más importantes de la filosofía latinoamericana, si en realidad quiere mantenerse vigente ante los nuevos retos y desafíos que impone la vida cotidiana de una sociedad como la nuestra.

A través de esta perspectiva crítica planteada por el autor, su principal hallazgo es que "la filosofía latinoamericana [...] no ha sabido responder todavía al reto del tejido intercultural que caracteriza la realidad cultural de América Latina” (Fornet-Betancourt, 2004: 14) y que es preciso enfrentar esta limitación si entre nuestro propósito pretendemos el reconocimiento 
de la interculturalidad asociado a la justicia cultural que merece todo pueblo en el marco de las relaciones adscritas a las formas únicas de relacionarse con el otro y con el entorno, así como de construir a partir de dichas interacciones una manera de estar siendo en el mundo.

Desde la perspectiva de Fornet-Betancourt es posible evidenciar cierta orientación hacia los otros, en el marco de un estudio por la interculturalidad obligada a ir más allá de una concepción sobre las culturas como entidades cerradas en sí mismas y, más bien, concebirlas a través de un conjunto de relaciones por medio de las cuales los seres humanos se habitúan a vivir en convivencia con los demás. Reconocer al otro, por tanto, instaura una necesidad continua de reaprendizaje, que se asocia también a un replanteamiento interminable sobre lo que significa la cultura y el contexto; respecto a las prácticas culturales, por ejemplo, FornetBetancourt las considera prácticas de traducción, de comprensión entre los pueblos, de experiencias que no se desarrollan de una manera aislada sino siempre vinculadas a un contexto, a unas tradiciones y a una historia particular.

El otro es entonces, principalmente allí donde nos sale al encuentro en la alteridad de una forma de vida o cultura, una perspectiva sobre el todo. Y de ahí precisamente su posibilidad de respectivizar nuestra propia perspectiva. No obstante condición de esa posibilidad es justo la disposición a aceptarlo como aquel ámbito indefinido, más exactamente, indefinible desde mi posición originaria, desde el que se levanta un nuevo horizonte de comprensión u orden del saber (Fornet-Betancourt, 2001: 41).

En efecto, aunque Fornet-Betancourt es por muchos considerado el padre de la filosofía intercultural, podemos asir otras perspectivas intelectuales que han aportado significativamente al desarrollo de este camino entre culturas; uno de estos pensadores es el filósofo suizo Josef Estermann, quien invita a repasar otras formas de racionalidad filosófica en una de sus principales obras: Filosofía Andina (1998) en la que busca demostrar la validez de la diversidad epistemológica como saberes legítimos de los pueblos andinos, problematizando el asunto de los saberes ya constituidos y válidos únicamente para algunas culturas hegemónicas habidas a lo largo de la historia. 
Diana de Vallescar en su artículo "Coordenadas de la interculturalidad" (2001), señala el papel predominante de la filosofía intercultural en la apuesta por interpretar una realidad disonante que debe corregir las concepciones exclusivas de la filosofía occidental en torno al papel de dominio tan notables al interior de la filosofía misma. Además, problematiza el concepto de filosofía intercultural, ya que señala que ha sido muy poco trabajado en el ámbito de la academia.

La filosofa intercultural se asemeja a una filosofa de los caminos. Los caminos de aguas, luces y estrellas que atraviesan los campos, pero también aquellos de piedra y asfalto, por los que han transitado y transitan la gran variedad de culturas, bajo la figura de los peregrinos, los navegantes, los comerciantes, los conquistadores, los extranjeros, las mujeres, etc. (Vallescar, 2001:386)

Es pues esta gran variedad que interioriza Vallescar desde la conjunción polifónica, la que permite interpretar la realidad de América Latina desde el relato, desde los bastos paisajes y de la fragante naturaleza, en el encuentro de saberes culturales visibilizados a través de la fuerza espiritual como portento legítimo de la filosofía intercultural, que no busca erradicar o negar las tradiciones filosóficas, pero sí pretende resaltar los valores interculturales que habitan en América Latina porque constituyen un aporte válido a la filosofía, en general y a las concepciones no académicas del pensamiento, en particular.

La filosofa intercultural nace en estrecha relación con una nueva forma de comprender las culturas y su mundo, vinculada a una interpretación crítica del modelo predominante tradicional de racionalidad filosófica y su respectiva cosmovisión, que se ha mantenido por tantos años no sin consecuencias que lamentar. (Vallescar, 2001:390)

Para Vallescar, es prematuro considerar algún tipo de disolución de la filosofía intercultural, como lo sugieren ciertos detractores partícipes del proyecto transcultural, sin embargo, llama la atención respecto a la pertinencia de nuevos esquemas teórico-prácticos que estimulen las 
polifonías sapienciales y espirituales de las comunidades en términos de filosofía intercultural. El mismo Fornet-Betancur (2009a), se pronuncia ante esta situación:

\begin{abstract}
Ya se sabe que los defensores de la transculturalidad reprochan a los "interculturalistas" el entender la cultura como "esferas", "islas" o "contenedores", es decir, como entidades homogéneas que no poseen sólo características acabadas y definidas esencialmente, sino que además representan puntos de referencia seguros y obligatorios para la formación de la identidad de sus miembros. Dicho con otras palabras, el reproche ya conocido de la transculturalidad consiste en sostener que la interculturalidad trabaja todavía con un concepto de cultura que desconoce por completo la historicidad y la flexibilidad de las culturas y que, por consiguiente, ontologiza los desarrollos y los procesos culturales. (p. 71, 72)
\end{abstract}

Por su parte, Vallescar (2001) sitúa «a finales de los años 80 y principios de los años 90 aparecen las primeras publicaciones acerca de la constitución de la filósofa intercultural»(p. 395), lo que significa un vasto campo intelectual que aún falta por explorar, en aras de fortalecer el núcleo común que reúne a intelectuales afines a este movimiento. Encontramos, por ejemplo, la posibilidad de abrir no solamente desde escenarios ético-políticos y epistemológicos, un camino de interpretación fijo, sino precisamente la multiplicidad en gran parte desconocida de la filosofía intercultural anegada en el pensar desde la alteridad del mundo, desde las alternativas nacientes de realidad que se des-oculta a la América Latina desconocida.

Así mismo en el artículo "Filosofía de la alteridad intercultural en América Latina" (2013), Álvaro Márquez-Fernández evidencia la conexión de la filosofía intercultural con la búsqueda y compresión del ser, es decir con el reencuentro no solo de la identidad cultural de los seres humanos desde su estar en conexión con la tierra, sino la trascendencia ontológica e intersubjetiva que brinda una semántica de autenticidad existencial en el individuo mismo: «Es en la esfera del despliegue ontológico de la intersubjetividad donde se hacen manifiestos los orígenes auténticos de nuestras culturas en sus praxis ancestrales» (Márquez-Fernández, 2013: 7). Lo que señala Márquez-Fernández es un atisbo esencial que aporta a la filosofía 
intercultural no solo un constructo filosófico, sino un vértice ontológico que emerge del trasegar ancestral latinoamericano, desde un carácter intercultural fundamental y como parte de las dinámicas vitales de los pueblos mediante expresiones simbólicas, espirituales, cosmológicas, racionales, musicales, entre otras, que representan la constelación relacional del sujeto con la naturaleza.

Uno de los filósofos más influyentes en la filosofía intercultural del siglo XX ha sido el pensador español Raimon Panikkar, quien ayudó a prefigurar toda una propuesta en primera instancia, de la interculturalidad y en segundo momento, de la unión de la mirada intercultural con la filosofía, dando cabida a lo que se llamaría en adelante la filosofía intercultural. Panikkar hizo grandes aportes a la filosofía intercultural, uno de ellos fue la crítica a la supuesta objetividad de las culturas imperantes, pues según el autor estas civilizaciones intentan absolutizar los valores que cada cultura trae consigo; de igual manera propuso una mirada crítica del "mito globalizador" por el que han pretendido cobijar la totalidad cultural del mundo bajo una sola manta semántica a través de reglas de juego sobre las cuales se debía comprender e interpretar el mundo y la realidad de manera homogénea.

Las culturas son mutuamente inconmensurables. Por el hecho de que todos formamos parte por lo menos de una cultura, no puede haber un punto exterior, "neutral", desde dónde valorar o juzgar otras; siempre dependemos del lenguaje y de los criterios de verdad de nuestra cultura y, como consecuencia, no hay posibilidad de establecer ninguna jerarquía entre ellas, ni tampoco de pretender que los valores de una sean aplicables a las otras en cualquier momento, es decir, de absolutizar o de universalizar los propios valores. Solamente podemos hablar de invariantes humanas, es decir, aquellas constantes como son pensar, hablar, creer, querer..., comunes a toda la humanidad, que cada cultura interpreta de manera diferente y distintiva (Panikkar R, 2006: 129).

En el mismo sentido en que venimos acercándonos al concepto de cultura en referencia con el ser latinoamericano, el filósofo argentino Rodolfo Kusch nos permite descubrir una postura filosófica permeada en Pensamiento indígena y popular en América (1973), América 
profunda (2000) y La seducción de la barbarie (2000), desde los que aborda un sentir intercultural de la filosofía frente a los procesos que legitiman la identidad de los pueblos indígenas en América Latina. Son las comunidades ancestrales quienes otorgan validez a la búsqueda de un sentido originario que Kusch develará en lo que él llama "demonismo cultural" y que concibe adscrito a las geografías del sur: «con otras palabras: es un proceso eminentemente polifónico donde se consigue la sintonía y armonía de las diversas voces por el continuo contraste con el otro y el continuo aprender de sus opiniones y experiencias» (Fornet-Betancourt, 2001: 29). La tarea no resulta ser simple, primero es necesario abandonar todas las etiquetas culturales concebidas especialmente desde el arribo de la colonización:

Por otra parte, un desafío central en esta empresa de reaprender a pensar desde la experiencia de la interculturalidad radica en la superación del paradigma de la dualidad "sujeto-objeto", en ir más allá de los límites marcados por un proceso cognoscitivo centrado en la dialéctica del sujeto conocedor y del objeto cognoscible, para fundar un movimiento dialéctico dialógico cualitativamente superior, a saber, un movimiento de comunicación y comprensión sustentado por la libre y recíproca explicitación de la "respectividad" de la correspondiente perspectiva inicial de todos los sujetos cuyas voces concurren al coro polifónico del diálogo intercultural (Fornet-Betancourt, 2001: 98).

Fornet-Betancourt, rompe con el esquema dualista de individuo racional que construye sociedad cuya representación responde al "mito fundacional" de la polis griega, al observar que en América Latina el horizonte político no se reduce a un individuo que piensa, sino que consiste precisamente en una relacionalidad de la naturaleza con los individuos desde sabidurías antiguas latentes que coexisten en el territorio, muy similar a lo que Kusch menciona respecto a la imponencia del paisaje e inclusive del miedo que suscita en los seres que habitan sus lugares. El hombre como ser histórico, se ve implicado en un contexto determinado como una parte del engranaje de la totalidad, una figura sostenida por el argot de una época, de una cultura, de un tiempo explícito en la realidad. Por esta razón, la alteridad constituye un componente fundamental sobre el cual se debe prestar atención, debido a la carga simbólica dentro de lo propuesto por Fornet-Betancourt, a saber, que «la 
interculturalidad no apunta entonces a incorporar el otro en lo propio» (Fornet-Betancourt, 2001: 47) sino mejor a cognacer junto al otro, en una construcción hermanada y emanada del manifiesto ser.

En contraste con lo anterior, el filósofo argentino Horacio Cerutti Guldberg, en su artículo "Dificultades teórico metodológicas de la propuesta intercultural" (2010), realiza una fuerte crítica a la filosofía intercultural de Fornet-Betancourt, donde resalta principalmente que dicha filosofía se ha construido bajo las propuestas de otros filósofos, de esta manera, además de restarle originalidad, sospecha que lo expuesto por el filósofo cubano no supera completamente los límites impuestos por el pensamiento eurocéntrico para, finalmente, señalar como insuficiente la réplica de la inculturación como respuesta que la filosofía intercultural da frente al reparo instigador ejercido por la filosofía occidental.

Así mismo el filósofo Chileno Ricardo Salas Astrain en su texto de cátedra "Filosofía intercultural, globalización e identidad. Reflexiones sobre el desarrollo desde América Latina" (2003) indica que la perspectiva de la filosofía intercultural tiene ambigüedades teóricas frente al proceso de globalización que sufre el mundo y por tanto no puede plantearse una total independencia de las culturas, pero tampoco una forma monolítica de relación entre los países dominantes y los países sumisos. Salas propone que debe aclararse qué entendemos por filosofía intercultural, ya que esta concepción está cada vez más mediada por la globalización, ampliando su concepción y generando confusión en la diversidad aglutinante desde donde se postulen tales argumentos.

Franz Martin Wimmer filósofo austriaco, en "Filosofía Intercultural ¿Nueva disciplina o nueva orientación de la filosofía?" (1995), reconoce que filosofar tiene una relación directa con el lugar donde se enuncia y que todas las culturas tienen cierto grado de influencia de culturas externas, lo que hace que sea válido hablar de la filosofía intercultural como un proceso natural de construcción tanto individual como colectiva de los distintos pueblos de la humanidad. El autor posiciona tres apéndices que hacen posible hablar en términos de una filosofía intercultural, a saber, que «las cuestiones de ella conciernen en esencia a tres 
campos: la estructura de la realidad, la cognoscibilidad, y la argumentación sobre normas y valores, en otras palabras, si consideramos la ontología, la gnoseología, y la ética como el núcleo de la filosofía» (Wimmer F, 1995: 7).

Por ello, el lugar de enunciación que postula Mignolo en su filosofía, puede tener conexión con lo dicho por Wimmer, al resaltar los rasgos característicos que se dan en la comprensión cognitiva del sujeto que enuncia y la cultura que lo permea. Esa realidad social sostenida por una serie de significaciones en clave con las tradiciones culturales, hacen explícitas en el discurso aquellas cargas simbólicas que, al tiempo, se convierten en práctica. Así lo expresa Kusch en la concepción de una geocultura del pensamiento, al subrayar los ejes constitutivos sobre los cuales se forja todo el entramado cultural de la semántica del vivir, así lo manifiesta Mignolo (1995), al respecto «este tipo de respuesta (y resistencia) a la occidentalización, que es único en América Latina, es la de Rodolfo Kusch» (p. 31).

La contextualidad es fuente de pluralidad, pero lo decisivo es comprender que lo es no por razones de simple geografía ni de compensación exótica sino por razones hermenéuticas y metodológicas, por razones éticas y religiosas, por razones culturales y antropológicas, en una palabra, por razón de lo que llamó Rodolfo Kusch (1922-1979) la "geocultura del pensamiento" sin cuya consideración nos parece imposible descubrir precisamente lo que está en juego, a saber, las riquezas de las razones con que la humanidad da razón de la vida (Fornet-Betancourt, 2001: 13, 14).

Finalmente, desde los textos de Fornet-Betancourt La interculturalidad a prueba (2006) y Tareas y propuestas de la filosofía intercultural (2009 b) es latente la consideración de los diálogos norte-sur, pero también sur-sur, pues desde allí no solo nos preguntaremos acerca de qué es importante conocer para nosotros, sino también cómo una "cultura del saber" es imprescindible en la puesta de la filosofía intercultural, la cual pone a prueba la seriedad epistemológica de los saberes otros y el fortalecimiento de la filosofía intercultural frente a los problemas actuales de la filosofía, pero también frente a los retos históricos que en ella aún existen. 


\section{ONTOLOGÍA DE NUESTRA AMÉRICA}

Este capítulo busca visibilizar las principales apuestas que se han venido generando ene 1 marco de la ontología latinoamericana, así como apreciar cierto énfasis tanto en algunos de sus principales exponentes como en sus respectivos postulados. Para ello, es pertinente recordar inicialmente lo que se comprende por ontología sin perder de vista la relación fundante con América Latina.

Al respecto, es preciso señalar que la ontología es el reflejo de la investigación del ser en sí en tanto que es ser, por encima, o más allá, de lo que es o existe en particular. A lo largo de la historia, muchos estudiosos han desarrollado variadas teorías referentes al concepto que pretende explicar la naturaleza misma del ser (lo que hay) en varios sentidos (ser, ente, existencia, realidad, entre otros), queriendo establecer las categorías primordiales y la gama de relaciones que de estas categorías iniciales se desprenden; en el caso específico de los autores latinoamericanos, es posible mencionar a José Vasconcelos, Juan David García Bacca, Josef Estermann, Agustín Basave y Rodolfo Kusch, como representantes a partir de los cuales han surgido contribución y reconocimientos de una parte de la realidad del ser que se encuentra más allá de la cotidianidad, de lo pragmático y de lo "obvio", de esa parte afectada por las circunstancias, el entorno, la cultura, la historia y tantosotros elementos que forman parte del crisol de la existencia en un amplio pervivir colectivo. Y es que, en efecto, para el caso de Latinoamérica, estas perspectivas se desenvuelven en escenarios e imaginarios anhelantes de ser identificados, porque «la identidad es algo que nos distingue, es algo que permite decir "Nosotros" y "Ellos". Nosotros somos un conjunto uniforme que es afecto a ser categorizado como ente distintivamente reconocible» (Cáceres, 2012: 4).

Hay que tener en cuenta, igualmente, la importancia de apreciar lo natural, lo rítmico y, en general, la vitalidad adscrita al contexto latinoamericano, relacionado en parte con lo que se ha denominado filosofía intercultural gracias a esa interconexión originaria de uno con otro y con todo, del que emergen pensamientos, formas de ser, y caracteres propios que colindan 
con lo pluricultural. En este sentido, muchos filósofos interesados en la ontología comprenden que se requiere cierta deconstrucción de las diversas racionalidades originadas en nuestras amañadas interpretaciones de mundo cuando pretendemos conocer la vida objetivamente. Ocurre pues que, en la búsqueda de un pensar propio y de las bases metafísicas que lo constituyen, es valioso para la misma filosofía latinoamericana progresar en investigaciones que manifiesten la diversidad del pensar y sentir en América Latina, entre las cuales se encuentra la fundamentación de una ontología, que resulta ser, en ocasiones algo tácita respecto a saberes, disertaciones y experiencias cotidianas y, en otras, oculta tras la identidad de comunidades menos explícitas. Resulta, entonces, una tarea imprescindible el diálogo de saberes entre una y otra forma de confrontar el problema del ser, así como de crear nuevas posibilidades que impliquen también a la filosofía clásica universal.

\subsection{Ontología del mestizaje como principio intercultural}

La metafísica de Vasconcelos es una reafirmación legítima del pensamiento latinoamericano en el tiempo y el espacio en tanto contexto. Pues si bien es indudable la influencia eurocéntrica que ha tenido su filosofía, es necesario subrayar el esfuerzo que denota el autor mediante otras interpretaciones de la realidad sumida en el cosmos; nos referimos a una construcción metafísica que tiene en cuenta la estética, la música y la poesía, de tal manera que encuentra en el arte algunos factores resultantes de una diferencia en el saber de nuestra América Latina frente a la metafísica occidental, por lo cual afirma que «la filosofía debiera ser por sí mismo, lo contrario de analizar» (Vasconcelos, 1929:7).

Porque en la empresa filosófica de Vasconcelos el concepto de ser no es estático, sino multiforme, es que no se limita a las pretensiones y/o concepciones que una Grecia clásica pudiera desbordar, por el contrario, «al pensar nos sentimos como involucrados en el Cosmos» (Vasconcelos, 1929:7), en una especie de forma musical, inmersos en el pentagrama del universo, en el que los entes son notas musicales circunscritas a la melodía del ser, a la forma rítmica que la ontología del cosmos nos ofrenda. 
Como escritor, Vasconcelos adelantó estudios sobre diferentes temáticas, las cuales abarcaban no solo aspectos filosóficos, pedagógicos y sociales, sino asuntos periodísticos, históricos y autobiográficos. Sin embargo, como filósofo estuvo influenciado por ciertas corrientes y personajes como Schopenhauer, Miguel de Unamuno, Bergson, Pitágoras y Nietzsche, entre otros. Es así, que en algunos de sus escritos procuró plasmar ideales como los de conjugar todas las áreas del ser y todas las facultades del yo en una unidad más de armonía que de "conocimientos" y racionalización. Gran parte de su pensamiento se regía por la idea de que la "belleza", la estética en términos de juicio estético y la armonía, permitirían alcanzar la verdad, a propósito «el descubrimiento de los primeros principios, de las entidades primarias, siempre ha sido el problema capital de la filosofía. Toda metafísica se ocupa de aquellas "existencias", de aquellas realidades indudables que pueden servir de punto de partida...» (Trejo, 2010: 205).

La principal propuesta de Vasconcelos, constituye una tentativa que invita a la búsqueda por el sentido del ser, además de hacer un llamado a la integración intercultural de humanidad, tras la publicación de sus textos en pleno siglo XX (1925-1929), donde la vertiente científica del darwinismo natural y social en América Latina se encontraba en auge, en el que «prevalecía en el mundo científico la doctrina darwinista de la selección natural que salva a los aptos, condena a los débiles» (Vasconcelos, 1948: 1); no menos importante que el predominio de las ciencias exactas es el hecho de que fueran, a su vez, aplicadas a los campos sociales.

En consecuencia, gracias a su gran interés por la metafísica, Vasconcelos desarrolla diversos conceptos en los que buscaba constituir un marco metafísico y estético acorde a la realidad mexicana. Así nacieron obras como Las nociones de "Raza cósmica", Indología, o Todología, por mencionar algunas. Para Vasconcelos, la filosofía tenía que ser universal, liberadora, sensible, simplificada, metódica, poética y espiritual; cultivó el interés por asumir una verdadera identidad empoderada y evolutiva referente a Latinoamérica, en su obra La Raza Cósmica Misión de la raza iberoamericana, en sus propias palaras expone que, a raíz 
de la confluencia intercultural que se comenzó a suscitar en nombre de la libertad, se fueron acrecentando las mixturas raciales, no solo a nivel local sino también a nivel internacional, «lo que presta apoyo inesperado a la tesis que, a falta de nombre mejor, titulé: de la Raza Cósmica futura» (Vasconcelos, 1948: 1).

Al respecto, cierta complejidad se hace plausible en relación con Vasconcelos al lograr identificar de forma creativa, no una historia inventada de seres que aparecen de la nada y forjar legados históricos que luego desaparecerían, como muchos críticos del autor lo han señalado; al contrario, su apuesta más parece un compromiso con el legado histórico frente al despojo de identidad al que ha sido sumido el pueblo latinoamericano, a través de cierta proyección metafísica que no se centra en el sujeto, en el ente, sino en la naturaleza y su historia. Este cambio de paradigma da ya destellos de una metafísica lejana a la europea, pues entiende factores complementarios al sujeto como la atmósfera y que emprende un camino hacia la interpretación y la legitimidad de otras formas de pensamiento.

Sobre esta línea de indagación encontramos a José Antoni Aguilar quien en su artículo “Después de la raza cósmica: respuesta a mis críticos” (2003) respalda la visión futurista de Vasconcelos en términos de mediación, es decir, en relación con un diálogo intercultural entre las partes del conflicto, sin llegar al absolutismo indígena ni mucho menos al europeo.

Nunca afirmé que las comunidades indígenas pretendieran restaurar el mundo indígena como «era hace 500 años». Los usos y costumbres que se pretenden reconocer no son prácticas sociales prehispánicas, sino un cóctel de elementos viejos y nuevos... «Los sistemas normativos indígenas —o lo que queda de ellos - son formas coloniales político-religiosas de ejercicio de la autoridad, profundamente modificadas por las guerras y la represión, en las que apenas puede apreciarse la sobrevivencia de elementos prehispánicos (Aguilar, 2003: 147).

Los elementos inherentes a su filosofía estuvieron, sin duda, marcados por caracteres metafísicos, espirituales e, inclusive utópicos, ya que constituían fines muy superiores de 
comprensión entre los pueblos. Por estas razones, el tratado de metafísica escrito por Vasconcelos en América Latina en 1929 no solo fue una piedra angular de la filosofía latinoamericana sino de la metafísica en general que, aunque tuvo bastantes detractores y críticos venidos de la filosofía europea, fue bien acogido en el ámbito latinoamericano y en adelante se convertiría en un legado de nuestro pensar en el sur, visibilizado por un rostro oculto, deforme y desconocido que poco a poco empezaba a salir a la luz: esperado por algunos, aborrecido por muchos.

La lucha contra el intelectualismo también fue un derrotero de su filosofía en tanto trataba de revalorar la percepción emocional con miras a la construcción de un sistema metafísico que, quería calificar de "monismo fundado en la estética"; resultado de su lectura de la teoría pitagórica como teoría rítmica, donde encuentra que las cualidades estético-metafísicas prevalecen sobre las meramente numéricas y matemáticas. El monismo estético vasconceliano pretende, finalmente, abarcar una parte de lo que llama "onda magnética a la Trinidad", a modo de metafísica literaria carente de estructura sistémica e instaurada en una profunda disposición religiosa.

Al respecto, Vasconcelos manifiesta un hondo interés por despertar nuevas conciencias generando inquietudes en torno a la ética y la filosofía; desde luego, este pensamiento estaba vinculado al momento histórico que atravesaban México y otros países de la región. Para el filósofo, los movimientos de reivindicación popular que habían provocado verdaderas revoluciones, no significaban un avance sustancial en las reformas sociales ni de pensamiento latinoamericano, sin embargo, repercutieron en Vasconcelos, quien comprendió la importancia de proponer métodos propicios para el mundo de los hechos, en términos más propios.

La propuesta enmarcada dentro de una ideología ontológica, plantea consideraciones cuya reflexión surgen como posibilidad de apertura hacia nuevos mundos mediados por disposiciones religiosas, al adoptar una teoría fundamentada en la vitalidad y en oposición al sentido de un universo material regido por leyes inalterables, al tiempo que dimensiona una 
ética que excede los límites pragmáticos y permite descubrir una existencia donde se obrase de modo menos utilitarista; en este sentido, la religión y el arte serían las disciplinas que sustituyen a la ciencia como vías hacia el alcance de principios esenciales. Se trata, en síntesis, de resaltar que la comprensión propia de la ética surge del conocimiento activo, es decir, aquel que coordina «elementos para organizar la energía y para impulsarla hacia maneras siempre ascendentes, trascendentes» (Vasconcelos, 1939: 719), de una metafísica intuitiva y existencialista, aplicada a un modelo de pensamiento que abarca múltiples esferas de la vida, del ser, particularmente dentro de la cultura latinoamericana.

Esta nueva perspectiva de integración multicultural a la que invita a pensar Vasconcelos significa una oportunidad para América Latina, en cuanto no toma el papel de receptor cultural de los grandes imperios en la modernidad, sino que establece un horizonte auténtico de realidad fundamentado en la diversidad que converge en un territorio: «la ventaja de nuestra tradición es que posee mayor facilidad de simpatía con los extraños» (Vasconcelos, 1948: 10); esta especie de facilidad adaptativa podría establecer la imagen de un nuevo mundo, de un nuevo hombre, de una nueva cultura.

También el blanco tendrá que deponer su orgullo, y buscará progreso y redención posterior en el alma de sus hermanos de las otras castas, y se confundirá y se perfeccionará en cada una de las variedades superiores de la especie, en cada una de las modalidades que tornan múltiple la revelación y más poderoso el genio (Vasconcelos, 1948: 9).

Lo múltiple, lo diverso, comienza a tener un valor importante en la resignificación histórica de América Latina, ya no como idea continental de unificación cultural, pues la respuesta nunca estuvo allí; más bien como proyecto que plasma la idea del encuentro entre los distintos y los extraños. Una invitación que emerge de la tragedia histórica y se consolida en el fulgor del reencuentro auténtico de la humanidad; de ahí que «comienza a advertirse este mandato de la Historia en esa abundancia de amor que permitió a los españoles crear una raza nueva con el indio y con el negro» (Vasconcelos, 1948: 10). 
Para Vasconcelos «el objeto del continente nuevo y antiguo es mucho más importante» (Vasconcelos, 1948: 10), ya que encarna un nuevo surgimiento racial producto del mestizaje, al trascender el concepto de "mestizaje" desde una visión impura y mundana, hacia una expresión de carácter autóctono de América Latina, es decir a una característica cultural que ayudaría a la reconstrucción de la imagen maltrecha: «su predestinación obedece al designio de constituir la cuna de una raza quinta en la que se fundirán todos los pueblos, para reemplazar a las cuatro que aisladamente han venido forjando la Historia» (Vasconcelos, 1948:10). Entonces es en los bastos suelos de América donde nace lo que denomina "quinta raza" al tomar forma, sentido y acción, desde el amor entre la humanidad para la superación de todas las estirpes y, al parecer, de todas las castas raciales.

\subsection{Hacia una metafísica ontológica original}

Filósofo español, docente, teólogo, físico y matemático, quien tras viajar por América del Sur decidió establecerse allí, donde ejerció como docente en México, Ecuador y Venezuela, desenvolviéndose como educador bajo dos corrientes: la logística y la metafísica. García Bacca fue tanto un innovador como el primer filósofo de habla hispana que enaltecía las metodologías filosóficas del criticismo, la fenomenología, el existencialismo, la epistemología en conexión con el marco teórico y conceptual de la lógica formal. Por otra parte, dentro de sus intereses metafísicos, hay una mezcla de la filosofía platónica, la ontología aristotélica y la lógica, de lo cual surgió un conjunto de obras que van desde una metafísica natural con leyes permanentes hasta una problemática metafísica espontánea. La nueva metafísica propuesta por este filósofo incorpora el pensamiento técnico y científico, que abarca desde la economía hasta la física cuántica y el principio de indeterminación para, con estos postulados, trazar un posible plano del sentido del hombre en un mundo cada vez más complejo y tecnificado porque «el hombre está atenido a sí mismo; es un producto natural, ha tomado en sí mismo y sobre sí su responsabilidad»(García Bacca, 1982: 16). 
Para este pensador, artífice de una nutrida y versátil literatura, es clave que abrió la puerta a una nueva dimensión ignorada, pero que, de todas maneras, tras ella logró comprender una relación entre la ciencia, la ética y la antropología, por nombrar algunos de los entenderes significativos de quien se atrevió a desafiar el modo convencional de abordar dicha relación, tratando de comprender de qué manera los avances científico-tecnológicos pueden transformar los tradicionales conceptos y normas de la moral.

Porque, al hablar de la técnica es imprescindible hacer referencia directa al ser humano como principal intérprete, García Bacca insiste en que la verdadera transformación de la naturaleza empieza cuando el ser humano es capaz de saberse diferente de los demás seres, por tanto, el hombre en su tentativa de hacerse diferente de lo que empezó siendo (hombre natural) puede arriesgarse a ser o a no ser: en el entramado de la vida «el hombre natural griego, romano, cristiano, es ya fin y final de sí mismo -diga lo que dijere la boquita oficial-» (García Bacca, 1987:17).

En cuanto a su postura ontológica, García Bacca llegó a Latinoamérica con todo un mundo nuevo de postulados vanguardistas e integradores en los que refleja, en el sentido último de su obra, la idea de que el ser humano tiene la posibilidad de transformar su existencia al tiempo que dicha transformación es sostenida por la capacidad creadora que lo establece ontológicamente como hombre. Asimismo, es interesante descubrir que parte de su postura daba cierta relevancia al error, en el sentido de que este sirve justamente para revelar que la realidad no depende de ninguna verdad, contario a la búsqueda infructuosa de respuestas últimas en términos verdaderos es lo que fundamenta a la filosofía moderna. La inversión del orden dará como resultado el hecho de que la verdad oculta la realidad, pero el error la descubre, el error manifiesta el ser en general, de forma independiente a sus circunstancias: «la ponderación filosófica de tales datos exige notar que la ley que une ambos extremos es cuantitativa y no puramente cualitativa, no hay diferencia específica, es una ley unívoca, en el mismo nivel "con forma de igualdad» (García Bacca,1990: 410). 
En última instancia, cabe mencionar que hay una evolución temporal en el pensamiento de García Bacca, aunque en todas ellas prevalece una serie de constantes que convergen en la elaboración del proyecto de una ontología de la probabilidad, de una antropología del hombre como creador y de una epistemología dialéctica modelada de acuerdo a los rasgos de la ciencia y la técnica contemporáneas. En consecuencia, García Bacca piensa que «lo natural, su propia naturaleza incluida, es para el hombre actual simple y bruto material para fines inventados por él, y con finales que él se propone por decisiones inventadas» (García Bacca. 1989: 24).

\subsection{Ontología Andina, una relacionalidad ancestral}

El suizo Josef Estermann, de gran formación filosófica y teológica, dedicó gran parte de su vida al estudio de las comunidades indígenas del sur de América, se radicó en Bolivia para continuar sus estudios sobre la posibilidad de encontrar en las culturas ancestrales atisbos de una filosofía Andina, situación que lo convierte en un referente obligatorio al interior de la filosofía latinoamericana.

Gracias a su trasegar por tierras andinas, nació en él una pronta y fuerte inclinación por modelos de pensamiento latinoamericanos, en cierta medida, bajo la influencia de las obras de Emmanuel Lévinas y de Johann Baptist Metz; fue así, que a partir de los años noventa, Estermann empezó a experimentar un cambio en su pensamiento, dedicándose al estudio de los saberes indígenas de América Latina; sus apreciaciones, señalan un matiz diferente a raíz de ser una mirada nativamente europea permeada por el contacto con una cultura étnica distante. Por ello, su configuración respecto a una ontología latinoamericana también radica en un deseo de interculturalidad que rechaza las pretensiones supra culturales, los supuestos límites absolutos entre las culturas y el desinterés ético entre ellas ostentado por el postmodernismo; asume, a su manera, una especie de vocería como intérprete de las culturas andinas, tanto a nivel local como a nivel externo: «en su intento de liberarse de su eurocentrismo y anatopismo latente o aun manifiesto, la filosofía latinoamericana se apoyaba 
en un primer momento en el llamado "mestizaje cultural" como característica específica de una supuesta "identidad latinoamericana"» (Estermann, 2008: 49); pensamiento que, bien podemos relacionar con el aporte de Cáceres (2012)

América Latina es un solo pueblo que debe ser autentificado desde su propia realidad ancestral milenaria y cada uno de sus habitantes, desde lo que es, juega el contraste de un verdadero colorido, que expresa las dimensiones más propias: religión, sociedad y hasta política (p. 70).

En un intento por relacionar dos conceptos aparentemente contrarios desde su formalidad, uno nacido desde el campo filosófico (razón) y otro que emerge desde la resurrección identitaria del pensamiento andino (realidad), Estermann despliega, por un lado, la racionalidad ortodoxa de occidente y por otro el conjunto de cosmogonías que representan la cultural andina, para invitarnos a de-construir los radicalismos culturales, pues solo de la hermandad entre ambas, es posible reflexionar acerca de una constitución epistemológica y ontológica desde las diversas realidades que logre «la explicitación (o en términos psicoanalíticos: la concientización) de los 'mitos fundacionales' solo es posible a través del diálogo intercultural» (Estermann, 1998: 97).

Sin embargo, la racionalidad andina que establece Estermann, de entrada, presenta una dicotomía conceptual semántica, a raíz de que el concepto de razón deviene de la cultura helénica y, por tanto, según el autor, no puede tener un carácter transcultural, es decir, no puede ser interpretado o aplicado de una manera distinta a la ya fijada por la historia eurocéntrica. En pro de brindar una alternativa que intente traducir aquellas concepciones inmóviles, Estermann se apoya en lo que llamará los "equivalentes homeomorficos", mediante los cuales es posible comprender las conexiones categóricas aún por encima de las diversas culturas humanas, sea andina o cualquier otra; significa que existen caracteres o significaciones similares a un concepto específico, en este caso el de "razón". Dado el distanciamiento cultural, epistemológico y lógico que toma occidente frente a las distintas 
formas de conocimiento en el marco de la diversidad de culturas, resulta ineludible la importancia de estas conexiones categóricas.

En la filosofía andina, se da el caso paradójico y hasta contradictorio (para la racionalidad occidental) de la 'relación sin relata', la 'relación sustancial', la' relación como arjé’. En otras palabras: todo es relación y relatum a la vez. La relacionalidad le es 'esencial' e inherente al relatum, y no algo que le 'acae' (accidental) en forma casual. Lo que la ontología llama "ente" ('sustancia' en sentido aristotélico), para la racionalidad andina es un 'nudo' de relaciones, un punto de transición, una concentración relacional (Estermann, 1998: 108-109).

Por ello, este autor postula que "la filosofia intercultural" es una necesidad universal ad portas del tercer milenio, ya que solamente por medio de variados diálogos (polílogos) se podrán evitar conflictos entre las etnias en particular y las culturas en general. No obstante, en términos estrictos de la filosofía occidental, la ontología andina no se enuncia propiamente como filosofía, porque «lo que pareciera una victoria de la apropiación popular del discurso "intercultural" y "descolonizador" puede resultar, desde un enfoque emancipador y crítico, un "secuestro" etnocéntrico, posmoderno y algo romántico de una herramienta de interpretación socio-política y cultural» (Estermann, 2014: 348), más bien es considerada una corriente falta de lógica metódica o sistemática determinada, ni es una ciencia como tal, porque no considera fundamental la separación culta entre algunos términos predominantes como filosofía y religión, conocimiento y salvación, teoría y práctica, ni el requerimiento de una lógica exclusivista:

'Racionalidad' no es simplemente 'el modo racional de pensar, actuar e imaginar'; no se reduce al análisis del pensar, ni siquiera a la actividad de la razón.

'Racionalidad' es una concepción más abstracta que los conceptos proto-genéticos (nous, logos, ratio), esta abstracción a la vez ha permitido una cierta liberación de las acepciones 'técnicas' de su fuente. Cuando hablamos de 'racionalidad andina', afirmamos que la 'racionalidad' solo se da en el plural: 'racionalidades' (Estermann, 1998: 100). 
De otra forma señala Estermann se entreteje ya no una lógica en su pura terminología sobre la racionalidad andina, pues esta se construye partiendo desde una simbología trascendental del signo a diferencia de la acción cognoscitiva de re-presentar las cosas en una definición o concepto como lo establece la cultura eurocéntrica. Por tanto, la re-presentación simbólica de la cultura andina toma distancia de los conocimientos ya dados o pre-concebidos por una razón estructural, para mostrar desde su creación natural "la re-presentación cultica y ceremonial de la misma" (Estermann, 1998: 100), una inserción mítica que genera ya no una adquisición de un objeto externo cognoscible sino una ontología en cuanto el sujeto se concibe y reconoce como parte de un todo simbólico.

Esta bifurcación epistemológica acerca de cómo se construye conocimiento en el mundo y su realidad, se haya en que para occidente la realidad solo puede ser pensada en términos lógicos mediante esfuerzos cognoscitivos, es en este proceso donde se encuentra la razón y su mecanismo de re-presentación binario entre el sujeto que conoce y el objeto cognoscible, haciendo mella en que la dualidad es un mito fundacional de la cultura occidental inmerso en el carácter gnoseológico que enfrenta constantemente procesos racionales. Forma contraria se evidencia desde la racionalidad andina, pues comprende la construcción de saberes, de una episteme o de una "presencia vivencial" de manera simbólica en la realidad en un todo relacionado por sus partes; la noción andina de la realidad es no-dualista, aunque a ojos occidentales la racionalidad andina ha sido hermanada a la fuerte influencia del positivismo en la modernidad.

La presencia simbólica y la conexión con el todo, son temas que Estermann toma como puntos de partida para sustentar la realidad ontológica desde la existencia humana a través de un lenguaje simbólico sin someter al dualismo el conocimiento que en su interior es propiciado. Desde la cosmogonía andina, la existencia óntica no puede estar separada, es decir, no es posible que el alma como esencia se halle por un lado y el cuerpo como substancia por otro, ambos son una sustancia compacta, en relación con o hacia algo o alguien, al respecto y «modificando una célebre frase de Martin Buber, podemos decir: "En 
el inicio (arjé) era la relación" (pero no restringida a la relación personal). La relación es para hablar en forma paradójica - la verdadera 'sustancia' andina» (Estermann, 1998: 108).

Asítambién lo ratifica en su tesis de maestría sobre Fundamentos Ontológicos en la filosofía andina de Josef Estermann el filósofo colombiano Jasser Sandoval, quien denota los pilares sobre los cuales se puede interpretar de manera ontológica la filosofía del pensador suizo:

El recorrido por la ontología en Latinoamérica muestra que la experiencia de la existencia de la vida es común a todas las propuestas y la adquisición de sentido es lograda por medio de la relacionalidad entre lo simbólico, lo ritual y lo sagrado; lo relacional como 'categoría' estuvo estrechamente vinculado tanto a la forma en que el ser se revela como al sentido de ser, estar o existir que tiene el hombre latinoamericano. En particular, sobre los fundamentos ontológicos de la Filosofía Andina se puede afirmar que estos se plantean en tres dimensiones: primero la relacionalidad como fundamento del ser, segundo Pacha como la totalidad del ser y en tercer lugar la chakana como forma de experimentar en la existencia el ser y el sentido que este tiene (comprensión del ser) (Sandoval, 2018: 92).

\subsection{Habencia, ontología libertaria}

La estructura del sistema filosófico de Agustín Basave comprende diferentes tópicos en torno al ser y al hacer humanos, de acuerdo a las disciplinas por medio de las cuales examina el ser del hombre como Antroposofía metafísica, Psicología racional, Lógica, Moral y Filosofía de la muerte.

Basave denomina a su sistema "Integralismo metafísico antroposófico de la Filosofía" como preparatoria para el estudio hacia la salvación. Esto se puede explicar porque, según el autor, en el ser confluyen todos los elementos en una sola unidad armónica: «en esta época de deshumanización política, he puesto especial empeño en la mostración precisa de cómo una 
ontología determinada del hombre explica todas las funciones y operaciones específicamente humanas» (Basave, 1955: 378). A propósito,

El filósofo Mexicano Agustín Basave Fernández hace su aporte a la ontología latinoamericana con su propuesta de la Teoría de la Habencia, una teoría metafísica novedosa que pretende darle una mirada diferente a la pregunta por el principio de todo lo que hay; se desenfoca de la pregunta por el ser porque «no hay ninguna "pregunta por el ser, como totalidad", [...] porque el ser no es una cosa sustantivada ni existe fuera de los entes» (Basave, 1982: 29), sino que busca encontrar eso que trasciende al ser, una realidad que lo fundamenta en su facultad misma de haber, en la cual el ser se actualiza o se hace presente en concreto (Sandoval, 2018: 23).

La propuesta de este Basave, concibe la ontología como una "construcción de ser" desde la memoria del latinoamericano, procurando descubrir el significado insondable de la propia vida encaminada hacia Dios. Así pues, le interesa la búsqueda de una explicación esencial de la realidad completa que alcance cierta sabiduría trascendental de los problemas humanos, puesto que, al estar en el mundo, el individuo tiene una tarea por desempeñar.

En este orden de ideas, descubrir tanto la propia finalidad como la del mundo, le otorgará a la persona una mejor manera de desarrollar sus actividades encaminadas hacia la plenitud. El ser, en búsqueda de la felicidad dispuesta por Dios, se encuentra en una especie de fusión coexistente entre el anhelo de la plenitud existencial y el desapego que confluye en el abandono ontológico «porque tenemos existencia de hombre captamos el sentido de nuestro ser y de nuestro contorno. Lo real nos está presente. Las cosas cobran sentido desde el hombre. Y las ciencias y el arte y la filosofía están hechas por el hombre para su propia integración y salvación» (Basave, 1962: 171).

Por otra parte, hay una cuestión que vale la pena aclarar en tanto este filósofo subordina la ontología a la metafísica de la habencia (sustantivo procedente del verbo haber, cuya acepción etimológica reside en designar "todo lo que hay, hubo y habrá"), de tal forma que fundamenta el ser más que en la realidad, en la habencia, en el horizonte de lo que hay donde 
se encuentran los entes y el ser. Sin embargo, Basave coincide con Kusch, al señalar el estar humano como algo distinto del ser, mientras el "estar en el mundo expresa relación a una manera de habitarlo, de sentirlo, de inmergirse en su ámbito espacio- temporal" (Basave, 1982: 43), el ser contiene toda la trayectoria mundana que especifica la condición ontológica.

La existencia humana consiste en "estar abierta" a las cosas y a los demás hombres. Esta apertura nos viene desde la esencia misma de nuestra intimidad más profunda. Somos co-seres que estamos referidos a las cosas, en un constante "enfrentamiento". Cosas que constituyen una unidad: el uni-verso (Basave, 1962: 172).

\subsection{Ontología de la estancia, como fuerza telúrica}

Escritor, antropólogo y profesor de filosofía por la Universidad de Buenos Aires, Rodolfo Kusch es reconocido por adelantar investigaciones de campo referentes al pensamiento indígena y popular americano, apasionado por todo lo relativo al conocimiento de las antiguas culturas precolombinas fundamentó sus reflexiones filosóficas en estas experiencias geoculturales.

Autor de varias obras literarias y filosóficas, en las que confronta el pensamiento proveniente de Europa, Kusch entiende que los pueblos de Latinoamérica, en contraste con el concepto del Ser, fundan sus culturas en el simple estar, en un estar opuesto al ser, pues si el ser es proyección y avance como lo suponen algunas ideologías europeas, los pueblos americanos consolidan su existencia en el estar inmersos en una totalidad de la que hacen parte, porque «lo indígena en el continente es más un estar que ser, el problema del ser se debate en el horizonte occidental por lo que, en Kusch, el estar comprende la vida pura del sujeto americano» (Bolaños, 2016, sp).

Las reflexiones de este filósofo argentino presentan un cierto "tinte orgánico", al lograr conectar con la esencia de América desde lo que refiere al hedor americano mismo, como un 
concepto de carácter desafiante en contra de los prejuicios sociales que menosprecian las raíces latinoamericanas. Señala así, la idea de que los americanos, quieren y necesitan develar su verdadera identidad desde un ser más legítimo, inherente a su vitalidad y anhelante de un desprendimiento de lo que le mantiene siendo lo que no es; por lo que hace falta una búsqueda de reintegración a la originalidad de ser, sin desdén por la tierra, lo natural ni lo vegetal.

Las emociones, los sentimientos y las opiniones también nos conducen a la verdad, y hacen parte de la verdad íntegra. Igualmente, la cultura, no hará parte de la verdad objetiva, pero sin ella no hay verdad. Y no se trata solamente del contexto cultural en que se da la verdad, sino que la verdad se da solamente como saber cultural. $\mathrm{O}$ por lo menos entre los seres humanos no puede ser de otra manera. Y esto se hace complejo cuando evidenciamos la pluralidad de culturas en que nos movemos, en que estamos siendo; pero, aún más: no solamente hay multiculturalidad, sino interculturalidad y transculturalidad. De acá la importancia fundamental de la filosofía intercultural a la hora de poder comprender una propuesta como la de Kusch: ella rebaja los prejuicios ratiocéntricos de la llamada filosofía universal y nos abre los oídos y el olfato para ofrecer el debido puesto a la otredad, es decir, a otras formas de la filosofía que no tienen por qué amoldarse a los principios, a las categorías, y a los métodos que una sola cultura quiere imponer (Cepeda, 2017b: 244).

Para Kusch más allá de mostrar parte de la ficción en la que nos hemos convertido, en nombre del progreso y la pulcritud, le interesa resaltar la imagen de la «simple sobrevivencia de machos y hembras que persiguen su fruto detrás de las murallas de la gran ciudad» (Kusch, 2000: 244), tomando distancia de la efímera inteligencia que solemos enaltecer, porque el fin es advertir al americano que se hace «preciso cancelar, desde ya esa libertad teórica y abstracta que se proclama en la gran ciudad» (Kusch, 2000:244) en el propósito por reconstruir la imagen natural de la condición humana, como meros machos y hembras que están dispuestos para el fruto. 
Igualmente, Kusch manifiesta el hecho de que no es favorable sesgarse hacia ningún extremo, pues así se corre el riesgo de caer en prejuicios, en la dificultad de no lograr interpretar plenamente que somos y estamos hechos de un todo del que participamos todos. No es extraño, pues, que por medio de su trabajo de campo en el noroeste argentino y en Bolivia, empezara a creer que la experiencia de América Latina albergaba una realidad ontológica y epistémica sin igual, a la que identificaba como una preponderancia del estar sobre el ser, disímil del estilo europeo en su prevalencia en el ser y en el ente: «en cierta manera es un mandamiento tácito, porque se da en una equiparación total entre la vida y la muerte, entre orden y caos, como hecho universal» (Kusch, 2000:250).

Un eje fundamental de su pensamiento reposaba en el significado entre los indígenas del concepto estar, contrario al de ser en tanto potencia según los occidentales. Por ello, Kusch comprendió que el estar es algo similar a la idea de "estar sentado", en el sentido filosófico de residencia, de sentirse refugiado en el mundo, en concordancia con el entorno, con la existencia. En este sentido, resaltaba la noción de inherencia, de introversión armoniosa con la totalidad del universo, para que, ante cualquier adversidad o conflicto, este sea restaurado con el equilibrio interno de esa totalidad. Al respecto, la posibilidad de plantear una ontología latinoamericana a partir de la inmersión en la identidad cultural, nos permite encontrar otras formas de ser; se trata, entonces, de revelar un nuevo horizonte humano, menos colonial, más auténtico y americano en el que «la vida es un equilibrio entre el orden y el caos, entre lo que es y lo que no es, porque no se puede impedir que el opuesto no exista» (Kusch, 2000: 249). Entre las posibilidades que apertura la existencia en estas tierras devela un nuevo sentido para la filosofía, en contraste

el destino de América es el de someter al presidente aquél y al inmigrante al vergonzoso mandamiento de que haya vida y no más bien muerte. Al fin y al cabo, es el mandamiento dictado por la gran historia y encontrado en la intimidad, en esa pregunta por uno mismo como simple ser viviente, despojado de toda figura, vienes y pretensiones, por el simple hecho de que aquí nos volvemos a topar con la ira de 
dios en los precipicios, en la montaña y en su pueblo, y es ella la que nos despoja (Kusch, 2000: 253).

Ahora bien, frente al referente ontológico que supone decidirse por lo equitativo, lo demostrable, lo tangible, podría contemplarse al Ser como unidad, como universalidad develada en la lógica del ser; más allá de que a simple vista pueda comprenderse una mera reducción del ser en una ontología del estar, desde una perspectiva de comprensión latinoamericana algunos pensadores saben que se trata, entre otras cosas, de una ontología de la emotividad (afectividad) que revela, por ejemplo, el puro vivir; en otras palabras, se trata de una ontología existencial que expresa el ser desde "el propio ser" por lo cual se hace patente también el mero vivir y existir, en este sentido «habría una relación de correspondencia entre nuestro quehacer diario y nuestro buscar fundamento en este existir» (Cáceres, 2012: 21).

Esta relación de complementariedad y absorción cultural de lo europeo hacia el hedor de lo americano se da en la fagocitación. La fagocitación comprende la esencia de lo que hiedeen América Latina y sortea el estado puro de las cosas, pues siempre hay un opuesto ante la afirmación «por eso el ser alguien y el estar aquí mantienen una relación como de hijo a madre» (Kusch, 2000:200). Ya lo advertía Kusch, en la fagocitación se da una especie de dialéctica que nace desde una hermenéutica de la realidad de lo americano, «entonces desde ese punto de vista indígena, es natural que se dé la fagocitación, ya que ser alguien es transitorio y de ningún modo inmutable y eterno» (Kusch, 2000: 200).

Para Kusch el estar aquí antecede al ser alguien, ya que no es posible ser alguien si en principio no se establece una configuración contextual donde existiera la posibilidad de ser, en este caso «el estar aquí es previo al ser alguien porque supone un estado de recolección, crecimiento o acumulación...» (Kusch, 2000: 201). De ahí que el estar para Kusch presuponga una dinámica que caracteriza elementos pasivos que cosifican lo americano «y es que el ser no puede darse sin el estar, porque en este último se da la vida en mayor proporción que en aquél. Aquél que surge del estar. El estar brinda al ser los elementos de 
su dinámica» (Kusch, 2000: 202) y Latinoamérica es un claro ejemplo de la oscuridad, el hedor, la fuerza caótica que también es.

La prueba está en Occidente. El afán de lograr la eternidad uniforme y el mundo de lo absoluto y esencial, a base de un exceso de tensión, de la exclusión del diablo, de la creación de la ciudad y de los objetos, ha llegado a su culminación y ahora no puede retornar a su mero estar para ser absorbido a fin de renovar siquiera sus fuerzas (Kusch, 2000: 203).

\subsection{Sentipensar ontológico, recogimiento del fruto ontológico desde América Latina}

Según el profesor y filósofo colombiano Juan Cepeda, la pregunta por el ser ha sido evocada en casi todas las culturas desde sus propias comprensiones lingüísticas, lo que permite admitir inclusive una diversidad de sentidos en torno a la cuestión misma porque encarna una disposición natural-existencial el preguntarse qué es el ser y cómo podemos llegar a una aproximación esencial del mismo. Los lenguajes, por su parte, nos permiten un acercamiento a la comprensión ontológica mediante vivencias, creencias, actitudes y disposiciones sociales, pues el ser se dice, pero también se concibe de muchas formas: «comprender quées eso que llamamos ser ha sido de un constante interés por los pensadores de las más diversas épocas, en múltiples culturas, y por las más variadas lenguas: óv, ens, essere, être, Sein, være, 是 , wees, ser, pacha, gu'...» (Cepeda H., 2017b: 8).

Es así como, según Cepeda, no es atrevido pensar en la diversidad de poblaciones indígenas, afrodescendientes, raizales, entre otras, que hacen la pregunta por el ser y, con la misma naturalidad expresen sentires que, aunque cuestionables para una cultura logocéntrica, sean legítimos desde los saberes propios de cada comunidad, de hecho, es posible que «¿acaso los indios que habitan lo que es la actual Latinoamérica se preguntaron por el sentido del ser?» (Cepeda H., 2013b: 15); al respecto, el pensamiento latinoamericano ha sorteado caminos propios de las raíces multiculturales que encarna, no posee un solo sendero racio-céntrico 
para conocer la realidad, no conduce un solo canal de pensamiento, pues precisamente lo latinoamericano contiene en sí la polifonía de las voces culturales que se sitúan desde el estar hacia horizontes de significancia propios, por eso «en nuestra América, no disponemos de las condiciones de posibilidad para dilucidar la esencia de una razón pura, ni deberíamos quererlo (a no ser cuando vuelve a imponérsenos una forma de pensar que no habla de lo nuestro ni desde nosotros mismos)» (Cepeda H., 2010: 167). De todas formas, queda aún la pregunta por el ser, cuya resonancia no estaría orientada desde la mirada universalizada de occidente, sino todo lo contrario, a saber:

En un viejo poema de origen tolteca se habla del principio supremo: Ometéotl. Principio omnipresente, en el ombligo de la tierra, en las aguas azules, en las nubes, en la región de los muertos y aún más allá de los cielos: "por todas partes, siempre eres esperado/eres invocado, eres suplicado". Es la verdad deidad, el principio divino verdadero (in nelli téotl), que se encuentra en el décimo tercer cielo, junto a su comparte (i-námic); sin embargo, esta comparte "no se trata de otro principio distinto, sino de lo que llamaríamos algo que se aúna con el principio supremo, o que comparte con él la condición de ser el nelli téotl” (Cepeda H., 2013b: 30).

Este encuentro con la alteridad de realidades que conviven en la propia y devienen constantemente en la configuración subjetiva, social y cultural, tiene una gran importancia en lo referente a la filosofía intercultural y, en lo que en adelante se convierten en sentires, percepciones, análisis, críticas y construcciones reflexivas del individuo situado en cada comunidad. De esta forma, el factor ontológico se desprende de una cotidiana relación metafísica con el hombre y el mundo que lo rodea y enfoca su análisis y semántica a la cosificación del ser resultante, del ser que se des-oculta (Cepeda H., 2010: 168).

En la búsqueda por comprender la filosofía desde otras tradiciones, se abre un sinnúmero de posibilidades quizás divergentes de la humanidad, construcciones de horizontes propios enlazados por la intención de descubrir el origen de las cosas; razón por la cual, el ser se transcribe ya no como categoría inmóvil de la filosofía, sino como vivencia existencial, por ejemplo, en las comunidades indígenas del sur de América, más allá de los esfuerzos de la 
tradición histórica occidental por deslegitimarla y aunque en la actualidad no se circunscriba a la validez filosófica en general, menos en tiempos posteriores a la modernidad, ante los ojos sintientes y reflexivos de una ontología latinoamericana pervive «lo sagrado de la existencia, lo sagrado de la vida, lo sagrado de ser y de estar siendo... pero no de la existencia como concepto abstracto y metafísico...» (Cepeda H., 2010: 174). De esta manera, la comprensión de la realidad es dada a partir de un pensar menos logocéntrico y más intrínseco a la vida, así lo explica el profesor:

Dentro de mis posibilidades se ser está la posibilidad de pensar, pero pensar corresponde a la tarea (y esfuerzo) de existir, de vivir. Pensar el ser es una posibilidad del pensamiento, pero no se puede -en los mismos términos- pensar el estar: éste se siente, nos afecta, nos motiva, desde la experiencia de nuestro puro vivir. Occidente ha pensado el ser y ha propiciado una cultura metafísica y logocéntrica. A Latinoamérica le conviene evidenciar el estar propiciando una cultura de la vida y la emotividad, promoviendo una ontología del estar y de la afectividad (Cepeda H., 2010: 175 -176).

Es en la obra Sentipensar ontológico (2017) que Juan Cepeda H., retoma la pregunta por el sentido del ser y apalabra mediante la reflexión lírica lo que es fuerza, ritmo y vida. Esta apuesta ontológica yace desde una rítmica interpretativa que ausculta el autor en lo que encuentra de ser en estas tierras, partiendo desde aquella triada seminal que posibilita un horizonte ontológico propio de la filosofía latinoamericana que ausculta lo que hay de ser, desde una perspectiva sentipensante permeada por un carácter analógico e intercultural.

\subsubsection{Fuerza primera}

La triada ontológica de fuerza, ritmo y vida por la que apuesta Cepeda expone, en lo que respecta a la fuerza, un paisaje ontológico donde los diversos elementos de la naturaleza emergen desde una condición seminal, «podría decirse, en una primera aproximación, / que la esencia del ser / no es otra que fuerza; / sin fuerza todo dejaría de ser» (Cepeda H., 2017a: 
130). De ahí que para Cepeda lo que es, es esencialmente fuerza, fuerza interior como el vigor del fruto que cae y germina, ya que «no podría ser de otro modo: / no puede no estar / lo que no puede no estar, / y ahí está: está siendo...» (Cepeda H., 2017a: 130), es la fuerza inicial la que permite a la semilla hacerse fruto y la que ejerce un impulso hacia el sentir desde donde nacen preguntas tan vitales como « ¿Sabemos sentir la fuerza de las cosas?, / ¿Aprendemos a sentir la fuerza del sentido?, / ¿Nos interesa comprender la fuerza divina de lo que es?» (Cepeda H., 2017a: 131).

Desde estos cuestionamientos, Cepeda nos ofrece un marco más amplio hacia la interpretación de la fuerza física, aquella fuerza material que para el autor se esfuerza en sersintiente, más allá de las connotaciones lógicas que buscan medir el ser, nosotros «no busquemos medir todo, / no seamos necios cuantificándolo todo» (Cepeda H., 2017a: 133), pues para Cepeda solo despojándonos de los prejuicios tradicionales de la cultura, podremos comprender que hay fuerza en el silencio, en la gota de agua y en la caricia íntima de la escucha. De ahí, alude el autor una posición crítica frente al pensamiento racional, haciendo un llamado austero al origen, al ciclo del fruto que es la vida, «idejémonos de tantas medidas!, / ino creamos tanto en objetividad! [...] busquemos, mejor, vivenciar / el rayo de luz, / la policromía del arcoíris» (Cepeda H., 2017a:133 - 134).

Para entender lo que es fuerza según Cepeda, debemos liberarnos de prejuicios formales del pensamiento para acercarnos a otras comprensiones del ser, pues la apuesta del autor solo es una más en la sumatoria de comprensiones acerca del ser: «libérate del dogma de la razón / y de la pureza de su objetividad» (Cepeda H., 2017a: 134), pues la fuerza del ser para Cepeda se da en lo mestizo, en lo diverso, en lo intercultural porque «no solo somos mestizos, / sino que toda la realidad es mestiza» (Cepeda H., 2017a: 134). En últimas lo que se halla en la fuerza es un revelarse seminalmente, pues para el autor «hay fuerza en la verdad, / la verdad no es más que fuerza / de ser» (Cepeda H., 2017a: 135), fuerza física pero también anímica, que habla en el silencio, se profiere en el alma y se purifica en el hedor.

Alma, en el fondo, es un lenguaje 
por el que se comunica

todo lo que es,

donde todo queda comprendido

en la identidad de su ser,

sin jerarquías racionales

que se inventan

sin saber en esencia lo que toda cosa es

(Cepeda H., 2017a: 136 - 137).

Para Cepeda, el alma es conciencia anímica de ser, una fuerza anímica que otorga a la vida un sentido sagrado mediado por el afecto, el equilibrio y el orden natural de las cosas, «esto es sabiduría, / y sabiduría primera, / vital para saber estar en el mundo» (Cepeda H., 2017a: 137). El estar que señala el pensador colombiano se pronuncia mediante la fuerza del alma que se devela en el ánimo; a saber, el "buen ánimo, poco ánimo, mal ánimo, desánimo, / son formas de encontrarse» (Cepeda H., 2017a: 137), sin embargo, son todas formas sintientes porque están afectas de ser, independiente de la causa que las inste, situación que permite apalabrar el ser desde otras posibilidades menos lógico sistemáticas, como la poesía, el arte, la danza.

De la fuerza física y la fuerza anímica, nace como tercera semilla la fuerza espiritual, con la cual el autor culmina el apartado de lo que es: fuerza, de esta manera "además de cuerpo y alma, / el ser humano / está siendo espíritu» (Cepeda H., 2017a: 140), Un espíritu que es cosmos y, también, culto en el sentido de fuerza integra presente en «la sabiduría primera / en la que encontramos / un primer principio / espiritual, / verdadeante, / que no se impone / ni siquiera por la fuerza de los argumentos»(Cepeda H., 2017a: 141 - 142). Entonces el espíritu, según Cepeda, está siendo en nuestras entrañas, hediendo en nuestra cultura, expresándose en nuestras formas existenciales, auscultando los saberes; todo ello representado en la fuerza del apalabrar o, mejor, sentipensar el ser.

La sabiduría no se engaña.

El espíritu no puede no estar, 
aunque para cierta cultura hieda;

el espíritu es seminal,

nos viene dado desde las entrañas;

no podríamos estar siendo

sin espíritu

pues, es ni más ni menos,

nuestra forma de ser,

aunque haya quienes le rechacen

(Cepeda H., 2017a: 142).

Para Cepeda, desligar al ser humano de su fuerza espiritual evoca una fragmentación existencial, pues «el ser humano es por antonomasia, / un ser espiritual; / no asumirlo retrotrae caos, / desarmonía / existencial» (Cepeda H., 2017a: 142). Entonces ¿qué es el ser?, ¿qué es lo ser?, ante este cuestionamiento, Cepeda realiza un primer acercamiento hacia una posible respuesta: «he aquí una primera aproximación: / ser es fuerza» (Cepeda H., 2017a: 143) para lograr conceptualizar en relación con la ontología, la esencia del ser. En este sentido, lo que la fuerza del espíritu verdadea está verdadeando en fuerza y esfuerzo ontológico de ser. A esta fuerza ontológica el autor la llama "óntico-anímico-espiritual” en el que la semilla misma que desencadena en cosecha se aproxima irremediablemente al ser: «Ser es semilla / que se realiza como tal / (semilla) / con todas sus posibilidades» (Cepeda H., 2017a: 145 - 146) y la semilla que se hace ser devela posibilidad, «ser es posibilidad / de perfeccionarse en su perfección»(Cepeda H., 2017a: 146). Que el ser se transfigure en términos de posibilidad, de semilla y de perfección sugiere una comprensión integral de la sabiduría primera, de esta manera, Ser constituye:

Hedor telúrico

yecto.

Lo que no puede no estar.

Fuerza seminal

Eso puede ser...

(Cepeda H., 2017a: 146 - 147). 


\subsubsection{Rítmica óntico-anímico-espiritual}

En la esfera elemental del lenguaje universal, Cepeda des-oculta un ritmo universal presente en todas las cosas. Así como lleva ritmo el alma y lo abstracto, también lo tiene el orden natural del mundo, de lo animal, de lo seminal, porque "no haynada sin ritmo / natural. ¡Hay música en el alma / de las cosas!» (Cepeda H., 2017a: 149). Así las cosas, estar en el mundo es estar sumergidos en la estancia melódica de lo que es, en una sincronía sagrada con el ser, en la aprehensión de que «hay un ritmo natural / propio de cada esencia / que armoniza y sintoniza / con su propio y todo otro / ser» (Cepeda H., 2017a: 150). De esta forma el filósofo colombiano nos invita a auscultar el ser de forma rítmica, melódica pero también silenciosa, puesto que esta es otra forma de estar-siendo, toda vez que "cada ser es humano es su propia música... / ritmando espiritualmente» (Cepeda H., 2017a: 151).

Desde este horizonte el ser para Cepeda más que pensarse, debe vivir-sentirse, o mejor sentipensarse, el «ser no es más que fuerza rítmica, / vivir no es más que fuerza rítmica, / amar no es más que fuerza rítmica» (Cepeda H., 2017a: 151); a propósito, uno está porque el ritmo

es y, en tanto el ritmo sea, habrá una «aprehensión rítmica del ser. / Tan se está siendo como se es estando» (Cepeda H., 2017a: 152) de la misma manera como las notas musicales en un pentagrama pierden su significancia si no existiera la otra nota que transforma su presencia en clave musical, así mismo sucede de manera semántica con el ser, susceptible de perder fuerza rítmica en tanto sea comprendido desde un horizonte objetivable, medible, racional, como lo expresa Cepeda (2017a)

En el estar se devela la melodía de lo que es...

Si el ser no es más que fuerza rítmica

-melodía pura y misteriosa-

¿qué otra cosa pueden ser todas las cosas

que están siendo?

Fuerza rítmica, melodía óntico-anímico-espiritual, 
que está

(p. 153).

En el fondo, también es un llamado al filósofo para que transforme su mero pensar y se proyecte a escuchar, a sentir y a vivir la fuerza rítmica de la natura, «se necesita que el filósofo se dedique a saber escuchar (¡Cuánto podría aprender de / amautas y tlamatinime!)» (Cepeda H., 2017a: 153), pues saber escuchar para Cepeda es un primer paso hacia una transformación sentipensante del ser humano, en el que al aprender a escuchar sea el ritmo que guíe el pensamiento, la sensación y el sentimiento «porque lo que es fluye y fluye, / que no es más que acaecimiento; / todo pasa, / pero todo queda, /porque todo está / siendo presente en su fuerza» (Cepeda H., 2017a: 155), aúnen la escucha del silencio y el hablar del pensamiento, aunque fuesen formas diversas no dejan de ser legítimas ante lo que es.

Esta brecha dada entre el ser y el no ser, es lo que Cepeda señala como perspectivas ontológicas inmersas en el "mestizaje ontológico" resultado de una combinación que el pensador colombiano explica en términos de una rítmica polícroma que va siendo desde un estar óntico hasta un estar ontológico, a saber: «entre ser y no ser / hay todo un mestizaje siendo y no siendo: / mestizaje ontológico / que no deja de ser» (Cepeda H., 2017a: 157). Pues para Cepeda este mestizaje que aparenta incertidumbre es un aporte a la sincronía rítmica del ser, pues «la nada siempre es más / en el perfeccionamiento del ser / que en su acontecer / enriquece su esencia / con sus posibilidades de ser» (Cepeda H., 2017a: 157).

Este sentido existencial del ser afirma Cepeda, no se constituye en el afán de existir, puesto que lo que es es y está dado, entonces el ser vive en la eternidad creciente del cosmos, en las posibilidades de la vida, por ello es ineludible «sentir lo sentido, / re-sentimiento que salva» (Cepeda H., 2017a: 162), no solo del pensamiento sino, también, de la acción rítmica del espíritu que se afirma en la semilla, en el fruto y en el estar. 


\subsubsection{Fuerza rítmica autopoiética}

En el último capítulo Lo que es: vida, Cepeda culmina su reflexión lírica definiendo lo que sentipiensa acerca del ser, es decir que nos brinda una noción que va más allá del mero logocentrismo, extendiéndose a las entrañas del hedor y del estar-siendo, quizás porque «hemos comprendido / la fuerza de ser: / ser como fuerza. / Luego, dimos un paso para comprender / el ritmo del ser: / ser como ritmo» (Cepeda H., 2017: 165); en primera instancia, hemos visto que para el autor el ser se concibe como fuerza, ya en un segundo momento el ser se da como rítmica seminal y finalmente, el tercer momento el ser encarna la combinación de los dos pilares anteriores añadiendo un significante más, la vida y su hedor, que conduce hacia lo autopoiético: «la vida hiede. / A los seres humanos la vida nos hiede / porque estamos bastante apegados / a lo vivo /... y a la muerte» (Cepeda H., 2017a: 166).

La propuesta, entonces, intenta evitar ser simples observadores de la vida para permitirnos escucharla, olfatearla, acariciarla, solo así es posible desde la mirada del filósofo, trascender de la mera existencia hacia el ser, pues la «vida es ser / y el ser en su estaridad no es más / que vida, / y nada más» (Cepeda H., 2017a: 166). Nuestro autor sabe que la vida trasciende lo que nosotros conocemos, paradójicamente bajo el mismo concepto, como vida, pues esta forma vital es solo una de las múltiples representaciones en las que se manifiesta, la «vida, en verdad, es la verdad / que se ofrece, / que se da, / en todo lo que es, / en todo lo que está» (Cepeda H., 2017a: 166 - 167) en clave de fuerza, rítmica vital que devela el ser:

Vida que se autoengendra,

por decirlo así:

autopoiética.

En este sentido

la mejor noción de la vida

se identifica

con la de ser:

fuerza rítmica autopoiética 
(Cepeda H., 2017a: 167).

La importancia que Cepeda encuentra en la vida orgánica va más allá de lo que conocemos, en definitiva «la vida, en su más profundo sentido, / no se limita al concepto / de que ella ofrezca la ciencia; / con ese concepto / no se puede comprender todo el sentido / de lo que es / y de como es." (Cepeda H., 2017: 168), una predisposición tal solamente la reduciría a una parte de la totalidad, razón por la que debe darse cabida al sentipensar con el corazón, «es por eso que sentipensar lo que es /exige una conexión de corazón / con toda la naturaleza y con todo el cosmos» (Cepeda H., 2017: 170) así como suscitar una mirada alterna hacia el razonar-con, que no conciba de forma limitada el pensamiento como algo ajeno de la realidad, pues para Cepeda razonar-con implica un esfuerzo de pensar «con-todo-lo-que-es y con-elcorazón), / es decir: co-razonar: / corazonar»(Cepeda H., 2017a: 170).

Nace también una conciencia ontológica impresa en el sujeto histórico que le permite pensarse como un ser autónomo, diverso y libre al interior de una naciente filosofía intercultural que propende por la urgencia del pensar latinoamericano como respuesta tanto a nuestra época como a la historia de la humanidad que olvidó por largo tiempo mirar hacia otras geografías pensantes. Se traza, de esta forma, un esbozo de pensamiento propio desde las adversidades que besan la realidad latinoamericana, en la complejidad casi absurda que retrógradamente ha percibido una única historia universal impuesta y contada, frente a distintas identidades relacionadas con sus contextos y prácticas inherentes, en búsqueda de cosmogonías como las que implican comunidades indígenas y raizales, nacidas y casi exterminadas en nuestra historia olvidada.

Por ejemplo, el estudio de la América profunda ha develado, entonces, cierta relación escindida entre el ser y el estar, con predominio de este último, como ya se dijo. Kusch comprende que el ser «surge del estar. El estar, brinda al ser los elementos para su dinámica», es decir que en la raíz del ser se encuentra el estar. Lo que suena a una lógica al revés, pues Occidente nos ha enseñado que el fundamento (arkhé) está en el ser: ¡el ser es! Lo que conlleva que volvamos a lo dicho más arriba: el ser 
no es sin el estar, es decir, la manzana no cae sino porque quiere, porque quiere reintegrarse al suelo. Nuestro suelo, pues, nos convoca... (Cepeda H, 2010: 169).

De ahí que la relación entre la ontología de Cepeda y la filosofía intercultural se pueda comprender en el sentido de un entretejer desde el ritmo ontológico hacia el movimiento filosófico con una intencionalidad más allá de lo político, fundada en la novedad y sustentada desde las prácticas de lo alterno, de lo periférico. Esta apuesta no tiene como fin una reubicación teórica ni filosófica sobre la herencia cultural que hemos recibido como pueblo latinoamericano y menos de una radicalización netamente discursiva frente a los postulados clásicos de la filosofía. Más bien se trata de impulsar, complementar y potencializar la filosofía en los distintos puntos de encuentro común desde otros sentires; en últimas, una filosofía continuamente abierta a la convergencia que convoca las infinitas formas y experiencias filosóficas de vivir la condición humana, la naturaleza y la comprensión del ser.

\subsubsection{La cosecha del fruto ontológico}

Las categorías ontológicas de fuerza, ritmo y vida, abren un abanico filosófico como posibilidad de interpretación del ser de manera orgánica y pragmática, en relación con aquellos principios de la filosofía intercultural de Fornet-Betancourt que evocan unesfuerzo por renovar a través de las posibilidades abiertas de las culturas no académicas, una legitimidad filosófica circunscrita a los saberes tradicionales de los pueblos.

En ese sentido es posible ligar la ontología intercultural de Cepeda H., con la filosofía intercultural de Fornet-Betancourt, en tanto que ambas apuestas intelectuales se encuentran encaminadas hacia nuevos horizontes de comprensión de la filosofía desde el ámbito intercultural, donde no separan conocimiento y cultura como estructura dicotómica del pensar, sino que las comprenden como parte de la constelación de fuerzas culturales y cognitivas redimidas desde otros saberes. 
En parte, la razón por la que el desarrollo del capítulo dos, ahondó más el pensamiento del profesor Cepeda en relación con los demás autores, es precisamente porque ha asumido la influencia de sus predecesores aquí expuestos para lograr, desde cada uno de ellos, cerrar algunas brechas en el marco de la ontología y propiciar los fundamentos seminales de su Sentipensar ontológico, es decir, en él han sido reunidos los argumentos filosóficos que justifican algunas posibilidades de la filosofía latinoamericana en la actualidad, al tiempo que direccionamos nuestra búsqueda en los fundamentos ontológicos propios de la filosofía intercultural de Fornet-Betancourt, teniendo en cuenta la gama de pensamientos desarrollados en este apartado. 


\section{LA FILOSOFÍA INTERCULTURAL DE RAÚL FORNET BETANCOURT EN CLAVE ONTOLÓGICA}

La filosofía intercultural propuesta por Raúl Fornet-Betancourt tiene como pilar la práctica de la libertad de los sujetos para realizarse de forma autónoma dentro de sus culturas y en la interacción con los otros. En consecuencia, el sentido de ser de los hombres no está dada de forma estática en las culturas, debido a las dinámicas constantes a las que se enfrentan. No obstante, muchas de las culturas latinoamericanas, así como algunas del resto del mundo, sí ofrecen un contexto al sujeto donde se delinean las relaciones que los hombres tienen con ellos mismos, con la naturaleza, con los otros y con las demás culturas a través del diálogo respetuoso.

De todas formas, en el incipiente registro cotidiano el sujeto se construye en la negociación que hace con el tipo de sujeto que construye su cultura para dotarse de identidad al tiempo que descubre su propia individualidad en medio de la alteridad. Gracias al legado cultural y a una disposición para hacer de la vida un espacio de manifestación social, las culturas logran intercambios, transformaciones y pactos que nuevamente modifican las condiciones culturales a partir de las cuales se desarrollan subjetividades.

Al respecto, la pretensión del presente capítulo es lograr visibilizar los matices que de ontología se hallen inmersos en la filosofía intercultural de Raúl Fornet-Betancourt; hemos preparado cinco apartados que consideramos contienen un valioso trasfondo ontológico: primero, "Humanitas", donde se expone el sujeto contextuado, libre y justo como alternativa al sujeto cartesiano-idealista; segundo, "De la feminidad ontológica", acá se trata la superación de la idea tradicional-patriarcal frente a la mujer como sujeto; tercero, "Espiritualidad latinoamericana", donde se revisan las teologías indígenas y afroamericanas; cuarto, "Identidad", como construcción contextual y posibilidad del sujeto de reconocerse 
en los otros; y quinto, "Interculturalidad y alteridad", en el cual se expone la relación que tienen los sujetos dentro del diálogo intercultural.

\subsection{Humanitas}

En el prólogo al libro Aproximaciones ontológicas a lo latinoamericano I del grupo de investigación Tlamatinime, Raúl Fornet-Betancourt hace énfasis en que los estudios que quieren ahondar en la ontología latinoamericana requieren dar apertura a su pluralidad cultural, al «recoger voces, memorias y simbologías de las culturas originarias, del mundo 'criollo' y de los pueblos afroamericanos» (Fornet-Betancourt en Beuchot et al., 2012: 9). Para el filósofo Fornet-Betancourt la indagación por la ontología, como sentido del ser y de la relación con el mundo y con los sujetos en las culturas de América Latina y en las demás latitudes alrededor del mundo, supera la racionalidad que rinde culto a los conceptos en la búsqueda de respuestas provisionales a raíz de la permanente transformación de las culturas, gracias a las tensiones internas vitales expresadas en los lazos y vínculos que sostienen. La ontología se de-vela centrando la atención en «las relaciones que configuran el tejido en que encuentran su sentido más hondo las cuestiones fundamentales por lo que somos, cómo somos y cómo deberíamos ser» (Fornet-Betancourt en Beuchot et al., 2012: 10).

La filosofía intercultural es el escenario propuesto por Fornet-Betancourt para promover el reconocimiento de las voces que vivifican las diversas culturas. Esta pluralidad cultural tiene como contexto «un proyecto alternativo de comunicación e intercambio entre las culturas como horizontes complejos y ambivalentes, cargados por contradicciones y conflictos internos. A este proyecto alternativo le doy el nombre de diálogo intercultural» (FornetBetancourt, 2001: 204), en un diálogo que lleva a cabo el plan de la filosofía intercultural en función de la generación de intercambio cultural y de la construcción de nuevos pactos sociales que, en consecuencia, configuran nuevas formas de ser en el mundo contemporáneo. 
Esta preferencia por el diálogo no deviene de un impulso democrático, o de una ética de la tolerancia y la asimilación cultural; por el contrario, proviene de la iniciativa por intercambiar ideas entre culturas como expresión del diálogo ejercido por los seres humanos dentro de sus núcleos sociales sin demeritar las subjetividades. Por ello, la «"cuestión por el ser” es también, siempre y con igual intensidad, una cuestión en la que se indaga igualmente por la calidad de lo humano y del diálogo entre lo humano y la totalidad del ser» (Fornet-Betancourt en Beuchot et al., 2012: 10). Si bien el diálogo intercultural se hace entre culturas, en él lo ontológico se manifiesta desde la configuración particular de los sujetos que expresan su ser permanentemente construido al interior de las tensiones de la propia sociedad.

La cuestión por el ser de Fornet-Betancourt encuentra momentos de articulación entre diferentes filósofos que se han dado a la tarea de desarrollar y aplicar investigaciones con base en la filosofía intercultural. El profesor y filósofo colombiano Juan Cepeda expresa, en concordancia con Fornet-Betancourt, en su texto Sentipensar ontológico (2017a), el significado del ser desde el sujeto:

La cultura de lo que es

emerge desde la comprensión vital

y originaria

del acontecer cotidiano en el que nos encontramos.

Ser es comprender.

El ser comprende su sentido ontológico

(Cepeda, 2017: 48)

Es así que, en las culturas latinoamericanas, como las indígenas y afrodescendientes, los sujetos son dentro de su cultura primigenia porque además de ser parte de ella han asumido una relación con el sentido particular del ser construido socialmente y, con igual énfasis, expresado de diversas maneras en la vitalidad de la interacción cultural. Es decir, los sujetos sienten su cultura y la piensan, de ello hacen una unidad que viven y transforman dentro de sus culturas tanto en la interacción, en general, como en el diálogo particular con los demás 
grupos sociales. Al respecto, Cepeda utiliza un verbo que resuelve la relación dialéctica entre la razón y el sentimiento: sentipensar, éste es, en clave musical, la expresión ontológica de los sujetos:

\author{
La unidad melódica de lo que es \\ está en \\ sentipensar: \\ sentir-y-pensar, \\ pensar-sintiendo, \\ pensar-con-sentimiento, \\ verdadear
}

(Cepeda, 2017: 74)

Los aspectos ontológicos de lo latinoamericano en Fornet-Betancourt no se encuentran aislados de otras disciplinas del conocimiento, por el contrario «se percibe con toda claridad también la centralidad decisiva de lo antropológico y sus experiencias» (Fornet-Betancourt en Beuchot et al., 2012: 10), lo que sugiere que la ontología se enlaza con una antropología manifiesta en la cotidianidad más que en el individuo en tanto ser independiente respecto a lo cual es posible hablar en términos de una antropología descentrada que da lugar a lo que Fornet-Betancourt argumenta en su libro Transformación intercultural de la filosofía (2001), a saber, que existe una necesidad imperativa del respeto real hacia las culturas, no para que estén estáticas, sino para que estas mismas se revisen y aporten al diálogo intercultural, buscando una universalización que permita mejores condiciones de vida en el mundo. Esta exigencia ética «no radica en asegurar la preservación o conservación de las culturas como entidades estáticas portadoras de valores ontológicos absolutos, sino la de garantizar la realización personal libre de los sujetos actuantes en ellas» (Fornet-Betancourt, 2001: 196) en una especie de ontología contextuada, vinculada irremediablemente a la cultura a la que pertenece pero siempre en disposición de apertura frente a la interacción con la diversidad de culturas, con el ánimo de forjar una universalidad que permita mejorar la vida en su totalidad. 
La propuesta filosófica de Fornet-Betancourt remite a la necesidad de una actitud atenta y dialógica, superando la escisión histórica entre la cultura impuesta y las otras, porque hemos reconocido que esta situación impide tanto un sentir verdadero como un pensar auténtico en relación con la influencia social y económica a nivel global de una creencia mayoritaria. De igual forma, es posible minimizar la categorización conceptual de las particularidades de esos otros como simples curiosidades para realmente valorar -no como folklore, sino como manifestaciones de construcciones culturales- las expresiones colmadas de sentido respecto a las relaciones del ser con el individuo mismo, con la comunidad y con la espiritualidad que los reúne.

El respeto por la posibilidad de construcción de los sujetos y sus culturas, así como la interacción dialógica intercultural, consisten en «la con-vivencia armoniosa y justa como concretización histórica de la humanitas o, si se prefieren los términos de Lévinas, del humanismo del otro hombre» (Fornet-Betancourt, 2001: 321) y el límite que FornetBetancourt propone para alcanzar una conexión entre unos y otros es la humanitas como «proceso de formación vital-existencial del sujeto» (Fornet-Betancourt, 2001: 316); tal sujeto hace referencia a quien es justo, más no a quien se justifica y significa que los sujetos en la filosofía intercultural deben respetar, dentro de su propio proceso de construcción cultural, el desarrollo cultural de los demás.

Fornet-Betancourt comprende la subjetividad, en conexión con la tradición filosófica del humanismo crítico-ético, como aquella subjetividad concreta y vital que «alimentada por la memoria de la liberación de todos los que han luchado por su humanidad negada, se funda como existencia comunitaria en resistencia para continuar dicha tradición» (FornetBetancourt, 2001: 312); en este sentido, la resistencia se torna fundamental para el reconocimiento de la humanitas de los otros como valor que debe ser realizado en y por cada sujeto. La subjetividad para Fornet-Betancourt está conformada por hombres que buscan ser justos en el respeto que merecen las posibilidades de los demás en relación con su autodeterminación y desarrollo, lo cual implica un imperativo que ha de conducir al rechazo de la imposición de condiciones que nieguen la posibilidad de identidad, así como al 
favorecimiento de la lucha por los derechos y la manifestación de escenarios favorables para el desarrollo de las distintas culturas, sin perder de vista el sistema socioeconómico neoliberal al que pertenecemos:

Pues si "metafísica" tiene quever, como con razón apunta Martin Heidegger, con el horizonte histórico a cuya luz se decide en qué relación está el hombre con los seres y su mundo, nos parece que es evidente entonces que el neoliberalismo es una "metafísica", porque pretende precisamente enmarcar y definir el horizonte desde el cual debemos comprender lo que somos y/o debemos ser, nuestras relaciones con los otros, con la naturaleza (Fornet-Betancourt, 2001: 341).

La metafísica que reviste al neoliberalismo, además de configurar un horizonte de sentido positivo es, para Fornet-Betancourt, un buen modelo de vida gracias a las relaciones de producción y consumo, sin embargo, para que este modelo universalice su horizonte de sentido requiere que los individuos inmersos en él lo asuman y forjen dentro de esta cultura socioeconómica su subjetividad, su identidad y su ontología; cuando esto suceda, el sistema habrá asumido «la humanitas, porque se ha logrado, para decirlo con Sartre, que el hombre se haga desde las exigencias de las instituciones del sistema» (Fornet-Betancourt, 2001: 344). De esta forma, es posible comprender en el marco de un contexto global, la necesidad prevista por Fornet-Betancourt de la autodeterminación de los sujetos y de las culturas, sumidos en el desarrollo de la humanitas para que puedan interactuar y transformarse más allá de las ontologías construidas, en una relación de consumo y producción orientadas hacia un horizonte de sentido compartido universalmente, forjado en las entrañas mismas del sistema sociopolítico actual.

$\mathrm{Y}$ aunque el sujeto para el neoliberalismo no es aquel que busca la justicia del respeto cultural dado que "el engranaje de la globalización no tiene ningún interés por el sujeto, porque lo que le interesa es la sujeción. Es decir que quiere producir y reproducir seres humanos acoplados a su mecanismo, neutralizados en su vitalidad humana» (Fornet-Betancourt, 2001: 350-351), cobra mayor importancia la preocupación por la liberación de los hombres de este 
estado de sujeción del ser, es decir, Fornet-Betancourt proclama la restauración del valor ético en términos de respeto del desarrollo subjetivo y cultural en concordancia con el planteamiento de la autodeterminación de las culturas dentro de lo que denomina la fílosofía intercultural.

Si existe un sujeto contrario al sujeto solidario y comunitario de Fornet-Betancourt ese sería el sujeto cartesiano-idealista «un sujeto que se construye desde el amor propio solipsista como individuo poseedor. La propiedad es su elemento de autojustificación» (FornetBetancourt, 2001: 357). Este sujeto es individualista al propender por su bienestar particular, por disponer de los recursos, del espacio y del tiempo de los otros, ignorando lahumanitas.

En este sentido, el sujeto cartesiano-idealista requiere entablar relaciones genuinas con las demás culturas, para que en un proceso de alteridad y reconocimiento se den transformaciones, donde la autodeterminación cultural se nutra de perspectivas que aporten a la capacidad de los sujetos de configurarse dentro de horizontes de sentido contextuados desde sus culturas originarias. Para Fornet-Betancourt, la cultura «no significa una esfera abstracta, reservada a la creación de valores 'espirituales', sino el proceso concreto por el que una comunidad humana determinada organiza su materialidad en base a los fines y valores que quiere realizar» (Fornet-Betancourt, 2001: 181). Por tanto, el desarrollo del diálogo intercultural se consagra como una alternativa para fortalecer la garantía del derecho a la autoderminación de la vida de las diversas culturas a nivel global.

Ante el desafío que impone lograr y ejercer la garantía de la humanitas de cada cultura, Fornet-Betancourt encuentra que la solución está en provocar una consciencia acerca de cómo los sujetos se han construido a partir de sus culturas y de la influencia de otras tantas, para que se recuperen «la memoria de la humanitas, y con ella su poder de subjetivización comunitaria» (Fornet-Betancourt, 2001: 347). De esta manera, se lograría que el multiculturalismo escuche atentamente la voz de las culturas y que en la democracia se construya a partir del respeto de las identidades culturales que la conforman. 
En este contexto, el sujeto por el que está interesado Fornet-Betancourt es aquel que es «fuente de visiones alternativas y foco de resistencia creadora ante la hegemonía del engranaje» (Fornet-Betancourt, 2001: 351-352), es decir, el que silencia sus rasgos culturales cuando no evita participar del diálogo con otras. Para llegar a ser sujeto de la humanitas se han planteado dos premisas: la primera, se requiere fundarse y ejercer como sujeto libre como condición para ser sujeto de liberación; y la segunda, el sujeto principalmente debe asir un saber autorreflexivo que le indica que es diferente a los demás, en el que «sabe por la práctica cotidiana y los consiguientes lazos y vínculos de todo tipo implicados en ella [...] que está viviendo un cuerpo cuya vivencia es experiencia de relación biológica y social» (Fornet-Betancourt, 2001: 353).

Este sujeto libre y consciente de su experiencia del contexto no divide su ser en mente y cuerpo, es decir, no dispone su mente a las exigencias de otras culturas, mientras que su cuerpo se signa por la experiencia cultural de su territorio; este sujeto sentipiensa, «es la consecuencia de una formación epistémica histórica» (Fornet-Betancourt, 2001: 359). En consecuencia, la ontología que compone al sujeto de Fornet-Betancourt está contextuada necesariamente en la cultura que lo gesta; este sujeto no interioriza un ser ajeno a ella, sino que construye su ser en la interacción que hace dentro de su cultura y fuera de ésta, sin perder su soporte relacional primigenio, es un ser que se asienta en la firmeza de la vida como convivir (ser-para, ser-con) con los otros.

Este sujeto ético que no lucha por su supervivencia, sino que se ocupa en la con-vivencia de todos es un sujeto que se funda éticamente en el respeto de la humanitas. Al respecto, FornetBetancourt califica al sujeto comunitario como el sujeto "bueno":

Este proceso por el que el sujeto vivo se va calificando como un sujeto bueno conlleva [...] la necesidad de una práctica crítica que sea capaz de ir corrigiendo las deformaciones producidas en la generación de la subjetividad humana por la idea y la realidad de la propiedad (privada). Si la propiedad (privada), y todo lo que su sanción social y política implica como poder atractivo y seductor, ha transformado 
al sujeto en un 'empresario' o en el afán de llegar a serlo, es hora de que el sujeto vivo (bueno) transforme esa transformación de sí mismo; una transformación que lo ha deformado en una "máscara", como diría Marx, o en un hombre institucionalizado y serial, como diría Sartre (Fornet-Betancourt, 2001: 368-369).

El sujeto bueno que plantea Fornet-Betancourt es, entonces, aquel que re-conoce y desnaturaliza la injerencia en la construcción de subjetividades que hace el sistema social para realmente buscar la fuente natural de su cultura, que resultan siendo las diversas relaciones con el entorno y las personas que su cultura primigenia ha construido en la convivencia.

Sin embargo, Fornet-Betancourt aclara que con este regreso a las fuentes culturales no pretende ontologizar las culturas como horizontes de sentidos homogéneos y llenos de coherencia, puesto que las culturas se construyen en el intercambio con otras y en la actualización que sus mismos sujetos hacen de ellas; Según Fornet «el ser humano vive en su cultura y tiene derecho a ella; pero tiene derecho a ella no solamente como su reproductor mecánico sino justo como su creador y posible transformador» (Fornet-Betancourt, 2001: 378).

En síntesis, Fornet-Betancourt plantea un sujeto coherente con la disposición reivindicativa de las voces de las culturas que hace la filosofía intercultural. Este sujeto busca hacer justicia a su valor-ético por el respeto al derecho de las culturas a re-crearse, es decir, por la humanitas. Fornet-Betancourt no de-construye ontologías de forma idealista, encasillando a los sujetos ni a sus culturas, porque comprende que los seres humanos se construyen dentro de sus culturas, al entender y vivir las distintas interacciones de sentido que se dan dentro de ellas. Lo cual genera una base para ser conscientes de las particularidades que los conforman como seres, para aceptarlas y, también, para debatirlas, formando su propia forma de ser, transformando y actualizando, a su vez, su propia cultura. Fornet-Betancourt aboga de esta manera por las condiciones que permiten una auténtica construcción del ser fundamentada en los propios sujetos. 


\subsection{De la feminidad ontológica}

Así como el sistema de producción extiende una configuración del sujeto alrededor del mundo en un proceso donde no se atiende cabalmente la humanitas, de manera análoga la voz de los hombres en la filosofía latinoamericana ha interpretado tradicionalmente a la mujer como sujeto, categorizándola sin más, sin verdaderamente dar lugar a una comprensión. No obstante, en su libro Mujer y filosofía en el pensamiento iberoamericano: momentos de una relación difícil (2009), Fornet-Betancourt expone cómo las mujeres han desarrollado paulatinamente aportes a la filosofía latinoamericana, superando la limitada participación en el campo de las ideas en el que los hombres ejercían dominio en una especie de monólogo androcéntrico.

Lo trágico de esta preponderancia masculina en el mundo de las ideas en América Latina consiste «no únicamente en el hecho del silenciamiento o de la marginación de la mujer sino también en que priva a las mujeres de su propia historia y de sus experiencias de ser y hacer, ya que se habla por ellas» (Fornet-Betancourt, 2009: 10). Desde la óptica de la filosofía intercultural, es un requisito para comprender al otro que este mismo se exprese, en este caso, las mujeres son quienes pueden dar luz sobre su propia manera de ser así como de su participación dentro de las culturas latinoamericanas.

En referencia a lo anterior, Fornet-Betancourt reconoce el positivismo como una corriente de pensamiento que influyó determinantemente en la construcción de las repúblicas en América Latina:

[El positivismo] se convirtió en una referencia paradigmática para la renovación de la pedagogía y de la educación en general. Lo que, para el caso de la mujer, quiere decir que ofreció el marco para un desarrollo cultural que contaba ciertamente con la mujer; pero manteniendo la discriminación sexista al fomentar su educación como “complemento" del orden varonil, es decir, educándola para que mejor cumpla el 
papel y el oficio que se le han asignado por el patriarcalismo (Fornet-Betancourt, 2009: 14)

La influencia del positivismo inculcó la idea en la sociedad latinoamericana de que el rol de la mujer estaba estrechamente ligado con ser apoyo para el hombre en el cuidado del hogar y de los hijos «así, bajo la idea de venerar a la mujer como madre y ser abnegado, se la discrimina y se la excluye de la vida pública y, en concreto, de la actividad científica y filosófica» (Fornet-Betancourt, 2009: 16).

El pensamiento de la mujer como ser reflexivo que aporta a la filosofía ha sido tratado de manera condescendiente por filósofos latinoamericanos como José Martí y Francisco Romero, quienes la reconocen como ser que está en capacidad de aportar pero que preferiblemente no debe hacerlo puesto que está para ellos dispuesta más para la abnegación y la ternura. Fornet-Betancourt entonces recurre a Georg Simmel para superar esa visión condescendiente, en sus palabras, Fornet-Betancourt reconoce que «el significado filosófico de la mujer es directo y su originalidad primaria, es decir, que su filosofía no tiene que 'pasar' por la del varón o definirse desde la relación con la de éste para tener sentido por sí misma» (Fornet- Betancourt, 2009: 45-46). De esta forma, Fornet-Betancourt nuevamente recurre a su compromiso ético por respetar la posibilidad del otro para formarse como sujeto cultural.

Posteriormente, Fornet-Betancourt analiza el pensamiento feminista de Rosario Castellanos, y encuentra que en el diálogo que tuvo con Simone de Beauvoir y con el estudio del existencialismo de Jean-Paul Sartre, descubrió la importancia de la categoría condición humana y a partir de ella comprendió que «la mujer es un ser históricamente situado cuyo primer desafío, para ser sí misma, es el de tomar conciencia de su situación en una historia y en un mundo dominados por los varones» (Fornet-Betancourt, 2009: 98), haciendo hincapié en la necesidad de todo sujeto de situarse en su cultura, comprenderla y, a partir de allí, formular aportes para transformarse a sí mismo y participar en la re-creación cultural, es decir, vivir su propia ontología a través del diálogo con su cultura. 
Fornet-Betancourt también trae a colación los aportes al feminismo de Graciela Hierro Pérez castro, filósofa mexicana, directora y fundadora del Programa de Estudios de Género de la Universidad Nacional Autónoma de México, quien desarrolla una ética feminista en la que da autonomía a la mujer, al separarla del ser para el varón y pasar a ser para ella misma. Se trata de una ética que orienta de forma práctica a la mujer para que «logre pasar del serobjeto al ser-sujeto, que es el paso del 'ser-para-otro' al 'ser para sî y que Graciela Hierro considera fundamental ya que ese paso presenta la condición indispensable para que un ser humano se convierta en sujeto ético» (Fornet-Betancourt, 2009: 101). Nuevamente, se reconoce la premisa del sujeto de Fornet-Betancourt que consiste en fundarse y ejercer como sujeto libre, para desde esta posición ejercer la crítica y la oposición a la dominación personal y cultural, en este caso, de los hombres sobre las mujeres.

Esta fundación del sujeto libre se reconoce en la filósofa hispano-venezolana Gloria Comesaña, nacida en 1946 en Vigo, España, quien supera el feminismo materialista que trata de explicar el sometimiento de la mujer a partir de fenómenos económicos y, también, el feminismo biologicista que a partir de diferencias naturales entre los sexos pretende justificar la desigualdad social entre hombres y mujeres. Estos feminismos entroncan en una ontología que empeña su consciencia en explicaciones patriarcales que le dan un rol en el mundo, es una ontología dominada y sumisa. Fornet-Betancourt encuentra que Gloria Comesaña comprende esta dominación ontológica y por tanto la supera fundándose en la idea de un sujeto que tiene libertad para autodeterminarse dentro de un sistema social en el que el hombre trata de imponerse. Fornet-Betancourt establece la siguiente aclaración:

Es en la estructura ontológica de la conciencia humana donde se decide el sentido que para una persona tienen la diferencia biológica y las condiciones históricas. Lo que significa que la derrota de la mujer tiene su causa profunda en las estructuras de la conciencia de la mujer porque la interiorización de la imagen que le presenta el orden patriarcal hace que la mujer considere que "su ser-para-otro es más importante que su ser para sí” (Fornet-Betancourt, 2009: 112-113). 
Al asumirse la mujer como alteridad del hombre, adopta la consciencia de ser dominado, esto se vuelve parte de su ontología. No obstante, abandonar esa consciencia de ser para el hombre, para pasar a ser para sí misma, constituye el giro ontológico que libera al sujeto femenino, desde los aportes que respectivos de Fornet-Betancourt y Gloria Comesaña.

\subsection{Espiritualidad latinoamericana}

En la filosofía intercultural, de la cual Fornet-Betancourt es precursor, se encuentra una gama de perspectivas intelectuales que aportan a su desarrollo. Es el caso del filósofo suizo Joseph Estermann, quien invita a pensar otras formas de racionalidad en su obra Filosofía Andina (1998), donde busca demostrar la validez de la diversidad epistemológica como saber legítimo de los pueblos andinos, problematizando el asunto de los saberes ya constituidos y validados principalmente por culturas con fuerte capacidad de universalización.

A partir del contraste de los horizontes de sentido impuestos desde la exterioridad occidental frente al empoderamiento de las comunidades aborígenes que emplean sus saberes y sentires ancestrales como principio y fin de la vida, Estermann abre un nuevo panorama interpretativo acerca de la significación de la relacionalidad intercultural que trasciende la concepción ontológica como concepto exclusivamente occidental y transforma entonces la unicidad de este concepto en sentires prácticos que devienen del flujo de la filosofía intercultural.

En la misma línea argumental, Cepeda, en el texto "Ontología indígena, aproximación

filosófica a saberes precolombinos que posibilitan una ontología latinoamericana" (2012), reconoce cómo para comprender el pensamiento de las comunidades indígenas latinoamericanas es preciso establecer un diálogo libre de horizontes de comprensión que no sean los suyos: horizontes que se han establecido a través de la historia de la filosofía de Occidente e imponen un conjunto de sesgos que limitan y afectan el estudio de las comprensiones que los indígenas latinoamericanos han desarrollado sobre sí mismos y sobre 
su entorno. Además, Cepeda problematiza la idea de la filosofía como ciencia de la razón que estudia precisamente los procesos racionales de las culturas con los que se interpreta la realidad, de modo que el autor rescata las experiencias espirituales y corpóreas como factores entrelazados con el pensamiento y el raciocinio.

A través de Cepeda es posible entender que superar el horizonte de comprensión del campo de la racionalidad hacia lo espiritual permite acercarse al establecimiento de conexiones transontológicas:

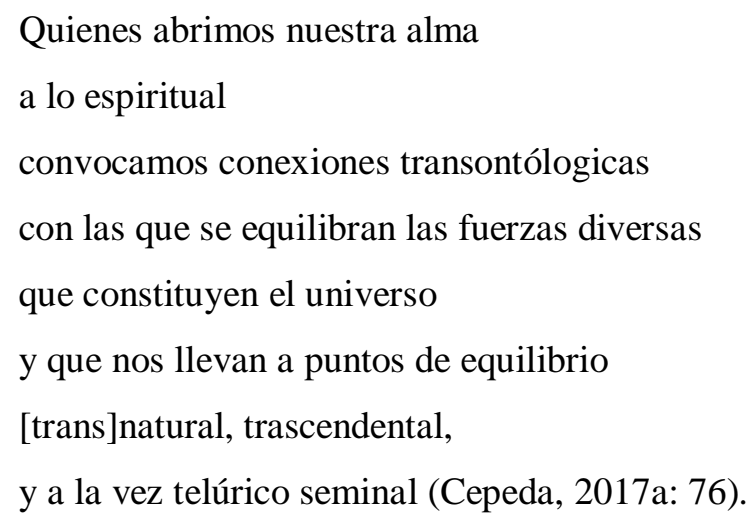

Esta comprensión del mundo espiritual como un universo que habita en los hombres y los conecta con su presente se expresa en Fornet-Betancourt a través del acercamiento que hace a la espiritualidad de los pueblos indígenas y afrodescendientes de América Latina. Para acercarse a la teología indígena, Fornet-Betancourt recurre a la teología de la liberación, la cual surgió en 1968 con la conferencia episcopal, celebrada en Medellín; a propósito, reconoce que la primera característica de la teología india (como la llama él) es su reclamo, al encontrarse con la teología cristiana, por el derecho a acercarse «a lo divino, un acceso histórico-vital propio a la inconmensurable realidad de Dios» (Fornet-Betancourt, 2001: 141), en consecuencia, la teología india no reconoce al cristianismo como única instancia de control o supervisión de su reflexión espiritual.

Una segunda característica refiere a que los pueblos indígenas respetan la construcción ontológica de cada grupo social y defienden esa independencia como un valor que deviene 
de las experiencias particulares, caso contrario a la imposición espiritual que tradicionalmente ha procurado el cristianismo: «la teología india niega someterse a la rectoría de otras teologías porque sabe que 'cada pueblo necesita ver a Dios desde su historia'» (Fornet-Betancourt, 2001: 141).

Precisamente, la tercera característica de la teología india consiste en esa consciencia de ser una entre muchas, de representar solo una parte del entendimiento de Dios, el cual habrá de ser complementado con las otras teologías en el mundo. Esa regionalidad de la teología india es «entendida como afincamiento en lo propio y como manifestación de un rostro peculiar de Dios, [...] condición hipotética para el diálogo» (Fornet-Betancourt, 2001: 141). Esta comprensión es condición necesaria para el diálogo teológico de acuerdo a la teología india, lo cual resulta coherente con la apertura dialógica que promueve la filosofía intercultural.

La cuarta característica aboga por finalizar la hegemonía religiosa que se adjudican las religiones autodenominadas universales, porque "la teología india quiere mostrar con su existencia que únicamente pueden existir teologías regionales, y que es hora de terminar con la clasificación discriminatoria de las religiones en religiones mundiales o universales y religiones locales» (Fornet-Betancourt, 2001: 142), para que haya la posibilidad de hacer un diálogo teológico. Aquí se observa cómo en los diferentes ámbitos de la vida las culturas que han tenido un ánimo y una fuerza imperialista han logrado universalizar su particular manera de relacionarse social y espiritualmente, lo cual oculta las posibilidades regionales de las diversas culturas, y en última instancia, las posibilidades de los sujetos de construir su propia manera de ser en el mundo.

La quinta y la sexta características se refieren a la inclusión del mito, el rito y la simbología en la teología india como una alternativa a la reflexión occidental de conceptos racionales y de la exégesis de un libro que contiene la palabra de Dios. Esta teología es un «proceso de acompañamiento reflexivo de la vida de la comunidad a la luz de sus tradiciones orales, ritos y símbolos. Es un momento práxico-reflexivo de la marcha hacia la vida de los pueblos indígenas»(Fornet-Betancourt, 2001: 143). Esta teología es vital porque se manifiesta 
continuamente en la vida, lo que permite a sus sujetos la experiencia de sentipensar su relación con Dios, lo cual marca sus relaciones ontológicas con ellos mismos y con el sentido que encuentran en la vida; es el caso, por ejemplo, del tlamantini o del amauta, quien «va configurando [...] el 'espíritu' de la visión amerindia, es decir, la que condiciona cómo ve’e interpreta el amerindio su mundo, sus relaciones con los otros, lo que acontece, en fin, el curso de la historia y su actitud en él» (Fornet-Betancourt, 2014: 48).

La séptima y octava características tratan el carácter comunitario de la teología india, puesto que hacen parte del proyecto social de la comunidad, a saber: «la teología india tiene por objeto la vida entera del pueblo o de la comunidad» (Fornet-Betancourt, 2001: 144), es una teología sobre el pueblo y su proyecto de vida, donde Dios está involucrado.

La novena característica devela que, para los indígenas, la teología tiene un carácter de liberación desde su propia cosmovisión sobre la base de los valores y las tradiciones, es «una teología de la liberación de la Vida, en el sentido de un proceso de liberación cósmica que haga posible la historia de alianza solidaria entre el ser humano y la naturaleza» (FornetBetancourt, 2001: 145). De esta novena característica se desprende una décima: que es una teología ecológica que vive la comunión entre el ser humano-comunidad y la tierranaturaleza, de esta manera busca mantener un equilibrio en la vida; en términos de FornetBetancourt una especie de temporalización de la historia: «temporalizada concretamente como una historia que libera la vida y la Tierra porque salva todas las formas de vida, y particularmente las vidas humanas» (Fornet-Betancourt, 2001: 145-146).

Desde esta perspectiva, la teología india está enlazada en la experiencia cultural de sus comunidades, en la vivencia subjetiva a lo largo de su historia en relación con un carácter vital, que ha permitido la experiencia cercana con la naturaleza. Por tanto, esta teología conforma un sello ontológico de los sujetos indígenas, al ejercer o incluso cuestionar en la construcción particular de su ser. 
En cuanto a la teología afroamericana, Fornet-Betancourt sintetiza las características comunes de las diferentes religiones que la componen, llegando a nueve características. La primera hace referencia a ser un discurso liberador de la palabra negra de y sobre Dios, en el que se mantiene «el recurso a la historia de resistencia y [la] articulación de la teología afroamericana, pero acentuando la presencia activa del logos negro en esa resistencia, es más: viendo en la resistencia misma una forma histórica y concreta de 'racionalidad'» (FornetBetancourt, 2001: 154-155).

La segunda característica es «ser teología del exilio y del vivir-en-frontera» (FornetBetancourt, 2001: 155-156), puesto que reflexiona acerca del destierro y el asedio cultural y religioso. La tercera característica se refiere a la relación con Dios: «Tiene por referencia última a un Dios único, pero que ella no puede situar ni determinar en sus cualidades divinas desde su discurso» (Fornet-Betancourt, 2001: 157). En últimas, es posible asumir que esta teología no tiene una referencia directa a Dios desde el discurso, los rituales y los cultos.

Al estar Dios más allá de las prácticas rituales y de la teoría, en la cuarta característica podemos concluir que esta teología es consciente de que «ningún tipo de religión o teología puede o debe elevar la pretensión de ser la morada exclusiva de Dios. La tolerancia religiosa y teológica es así una consecuencia por la que también se caracteriza la teología afroamericana» (Fornet-Betancourt, 2001: 158).

La quinta característica consiste en ser una teología de espiritualización, en la que el ser humano vive en un mundo donde combaten espíritus que pueden mediar ante Dios:

La "espiritualización” del mundo de la teología afroamericana significa así la articulación de la vivencia mística del cosmos, es decir, de la creencia de que el espacio y el tiempo son portadores de un sentido especial (espiritual) y de que el ser humano se ha de mover en ellos como en una "geografía mística". Con lo cual decimos, en suma, que es una teología que tampoco entrega al ser humano la clave del misterio de la identidad del mundo (Fornet-Betancourt, 2001: 159). 
La sexta característica argumenta que esta es una teología en la que hay comunión entre la vida y la religión, donde el espacio religioso está presente en todo lo vital. La séptima característica refiere al cuerpo humano, «no simplemente un instrumento para..., sino que es en sí mismo sujeto y morada de vivencias y expresiones religiosas» (Fornet-Betancourt, 2001: 160). En esta teología el cuerpo además de expresar inteligencia, manifiesta emotividad y afectividad por medio del baile y el canto, portanto, es una teología configurada como liturgia de la vida, así como de la muerte como parte de la vida.

La salud y la generación de vida humana en la tierra conforman la octava característica de la teología afroamericana. La novena característica es su sentido de comunidad dentro de la vida, el cual es «reflejo de la comunión cósmica en la que el ser humano se siente instalado desde siempre, y con la tarea de cuidar de su equilibrio» (Fornet-Betancourt, 2001: 162). Como décima y última característica, es ser «una teología cuyo material básico ha sido, y sigue siendo todavía, transmitido por vía oral» (Fornet-Betancourt, 2001: 163).

Podemos observar a través de las exposiciones de Fornet-Betancourt que la teología indígena y la afroamericana integran la espiritualidad dentro de la experiencia cotidiana vital, al tiempo que propenden por el respeto a la posibilidad de cada cultura de acercarse a Dios, abriéndose a un posible diálogo teológico en el que se compartan las diferentes concepciones de la relación entre humanos y ser superior.

Esta actitud respetuosa a los otros (humanitas) y la consciencia permanente de vivir en relación con la espiritualidad en clave de manifestaciones divinas, hacen que los sujetos indígenas y afroamericanos tengan una experiencia cultural que configura su ser de forma diferente a la población criolla cristiana de América Latina, lo cual enriquece el diálogo y el re-conocimiento que ejerce la teología de la liberación. La tendencia a la interaccióncultural y al intercambio de las teologías indígena y afroamericana están en sintonía con el dialogismo que cruza el sistema filosófico de Fornet-Betancourt desde la construcción cultural y 
ontológica del sujeto hasta llegar a la transformación de la filosofía a través del intercambio disciplinar y filosófico.

\subsection{Identidad}

Fornet-Betancourt establece como hito para la filosofía intercultural la conmemoración de los quinientos años del descubrimiento de América, cuando los pueblos indígenas y afroamericanos expresaron su necesidad de luchar por el derecho a vivir su identidad. Estos pueblos se movilizaron en movimientos socioculturales exigiendo autoderminarse política, cultural y religiosamente, «con esta movilización los indígenas y afroamericanos reafirmaban su presencia como sujetos de su propia historia, y con derecho a una cultura propia» (FornetBetancourt, 2004: 25).

Estas reivindicaciones, después de quinientos años de historia compartida, demuestran que América no es cabalmente el resultado del encuentro de dos mundos «es más bien un complejo mosaico de muchos pueblos y del comercio de otras tantas tradiciones. Por eso se impone un movimiento de aprendizaje que nos permita 'des-cubrir' realmente la realidad americana en su originaria pluralidad» (Fornet-Betancourt, 2001: 73), lo cual se logra gracias a la resistencia de las identidades culturales que, dentro de sus procesos de transformación, mantienen sus raíces para exigir autonomía cultural.

La vulneración del derecho de autodeterminación de las culturas indígenas y afroamericanas se explica por la preponderancia que ha tenido la cultura criolla en América Latina, subvalorando a las culturas que le son distintas, básicamente porque no están ampliamente integradas a su sistema económico. Para reconocer la validez de las culturas, FornetBetancourt se apoya en los cuatro criterios que propone Luis Villoro para este efecto, a saber: autonomía, autenticidad, sentido y eficacia. Mientras no se tengan razones para poner en duda la autenticidad de una cultura, se «tendría la obligación de suponer que las expresiones 
(verbales o no) de otra cultura son consistentes con sus deseos, creencias, actitudes o intenciones» (Luis Villoro, citado por Fornet-Betancourt, 2004: 66).

Fornet-Betancourt ejerce la poderosa iniciativa de promover el diálogo intercultural en el que los sujetos y sus culturas puedan compartir sus idearios culturales y, por tanto, transformarse en la diferencia. Por ello, le llama intensamente la atención la idea de la utopía de Fernando Ainsa, la cual propende por crear una identidad que se expanda desde el territorio y la singularidad hacia una apertura intercultural. Esta es la propuesta de Ainsa en palabras de Fornet-Betancourt (2004):

El mestizaje es el nombre propio con el que se apunta hacia la utopía de una condición humana que se realiza en hombres y mujeres que, sin olvidar su contextual condición ni sus "raíces", aprenden el habitar varios lugares y la convivencia en y desde ellos; y que, por ese aprendizaje, se reconocen, más allá de cualquier límite, como seres capaces de pertenecer a la vez a varios mundos -itambién a los mundos todavía posibles!- y entienden además que ese anhelo de ser todos los mundos es la vocación a lo universal que debe cultivarse en todos y todas con abierto espíritu de mutualidad (p. 97).

De esta postura del sujeto mestizo se desprende un sujeto ideal que es aquel que cumple con las premisas del sujeto de Fornet-Betancourt, al ejercer la libertad y al construirse en convivencia con otros, sin olvidar sus raíces culturales. Este sujeto contextuado ya tiene una ontología construida primero desde su cultura y luego desde la actualización que hace de ella en su subjetividad y en el diálogo intercultural. Por tanto, se requiere superar el multiculturalismo, en el cual, pese a que se proveen igualdad de oportunidades a las distintas culturas que han sido relegadas, no se establece un diálogo con ellas, omitiendo su calidad de interlocutoras. Con base en Fidel Turbino, Fornet Betancourt entiende que interculturalizar el multiculturalismo implica un programa de acción ético que trascienda el multiculturalismo al pluralizar la construcción social a través de la participación de sus diferentes culturas, «este proceso de interculturalización de todas las esferas públicas de la sociedad debe articularse en un nuevo pacto social» (Fornet-Betancourt, 2004: 103-104); 
ratificándose con ello el objetivo permanente de la filosofía intercultural de transformar las condiciones culturales desde las que se construyen los sujetos.

Fornet-Betancourt insiste en que los hombres y las culturas tengan una actitud de apertura al intercambio con los demás a partir de la tradición propia, es decir, sin anclarse en una identidad que tienda a considerarse absoluta y cerrada porque «nuestra cultura sería de este modo algo así como el puente que no podemos saltar, pero que debemos transitar si queremos llegar a la otra orilla» (Fornet-Betancourt, 2001: 31). La cultura es, en este sentido, una especie de lugar que abre caminos para intercambiar con los otros, generando transformaciones recíprocas e incluso pactos sociales.

Fornet-Betancourt reconoce que el diálogo promovido por la filosofía intercultural permite «la comprensión cabal de la cuestión de la 'identidad' de una filosofía, pero también la de la identidad cultural de una comunidad humana determinada» (Fornet-Betancourt, 2001: 31). En esta comprensión se re-crean las identidades en un proceso de transculturación, donde el filó sofo cubano continúa con la alegoría del camino y los caminantes: «Trans-portamos' nuestras tradiciones y dejamos que nos 'trans-porten' otras, y nos hacemos así agentespacientes de verdaderos procesos de universalización» (Fornet-Betancourt, 2001: 31). El intercambio y la actualización se presentan continuamente en la filosofía de FornetBetancourt como espejo de la existencia cuyo «sentido vital/ es dinámico, / se nutre y se enriquece/ su perfección/ está en perfeccionarse/ cada vez más» (Cepeda, 2017a: 51-52).

No obstante, el intercambio de aportes entre identidades culturales no solo tiene por objeto transformar las culturas y los pactos sociales, también es un proceso de resistencia en el que las identidades cuyas voces no han sido escuchadas en el diálogo social se sostienen en sus raíces culturales. Esta es «la resistencia cultural de pueblos que quieren guardar su memoria propia como un aporte o voz que no debe faltar en la sinfonía polifónica de una humanidad solidaria y libre» (Fornet-Betancourt, 2001: 44). 
Fornet-Betancourt encuentra en el diálogo intercultural el escenario en donde los sujetos portadores de su cultura reconocen su particularidad, es decir, aquello que les da una identidad cultural, al contrastar su pensamiento en los diferentes ámbitos de la experiencia humana con los pensamientos de los otros:

Reaprender a pensar desde la polifonía del pensamiento iberoamericano es así el verdadero comienzo de un proceso filosófico intercultural a nivel de nuestra herencia cultural. Pues es ahí donde aprendemos a relacionarnos con nuestro modo de pensar inicial -sea éste indígena, afroamericano o europeo- desde la con-vivencia con otras formas de pensamiento; con-vivencia donde experimentamos la posibilidad de transitar por varios "lugares" de palabra originaria e insustituible en su mensaje (Fornet-Betancourt, 2001: 97)

De tal manera que el hombre se construye desde su contexto cultural, es lo que le da la posibilidad de ser libre y la capacidad de razonar. El hombre «está en su cultura como en su situación histórica original, pero esto quiere decir precisamente que el ser humano es, a la vez, paciente y agente cultural» (Fornet-Betancourt, 2001: 198-199), se construye entonces de forma particular cuando asume su cultura y transforma su relación con ella en un proceso de construcción singular.

Pero este proceso se hace aún más claro y enriquece más al sujeto cuando interactúa en un diálogo entre pares con personas que han construido una ontología en lugares diferentes y provienen de identidades culturales distintas. En esta posibilidad de contraste el sujeto reconoce su propia identidad cultural, puesto que en este contexto requiere hacer una reflexión subjetiva que «convierte los límites [culturales] en fronteras, es decir, en zonas de comunicación, obligando con ello a que cada ser humano revise su concepción de identidad cultural de origen» (Fornet-Betancourt, 2001: 214).

Sin embargo, Fornet-Betancourt reconoce que aunque la filosofía intercultural da voz y espacio al indígena y al afroamericano como sujetos cuya participación requiere ser más 
determinante en la construcción de pactos interculturales así como en la formulación de la filosofía latinoamericana, son estos sujetos quienes imponen la tarea imperativa a la filosofía latinoamericana de «acometer un proceso autocrítico de reconstrucción conceptual y de reubicación cultural, para redefinirse como filosofía desde el diálogo con los imaginarios indígenas y afroamericanos y aprender a leer nuestra realidad y nuestra historia contando con ellos en tanto que sujetos de interpretación» (Fornet-Betancourt, 2001: 250-251). Es en este re-conocimiento y diálogo entre los distintos sujetos latinoamericanos como realmente se redescubren en tanto coterráneos, y, así mismo, en tanto que sujetos que por sus diferencias contrastadas reconocen que provienen de una identidad cultural con la cual han negociado en la tensión dialéctica entre libertad y opresión que se da en el núcleo cultural originario de cada persona, donde construyen y viven ontologías particulares.

\subsection{Alteridad e interculturalidad}

En el artículo "Filosofía de la alteridad intercultural en América Latina" (2013), Álvaro Márquez-Fernández evidencia la conexión entre la filosofía intercultural con la búsqueda y compresión del ser, a saber: «es en la esfera del despliegue ontológico de la intersubjetividad donde se hacen manifiestos los orígenes auténticos de nuestras culturas en sus praxis ancestrales» (Márquez-Fernández, 2013: 7). La filosofía intercultural permite el reencuentro de la identidad cultural de los seres humanos desde su estar en conexión con la tierra, y, además, da lugar a la manifestación de la trascendencia ontológica e intersubjetiva que brinda una semántica de autenticidad existencial en el sujeto.

Por su parte, Raúl Fornet Betancourt, en el artículo "La filosofía intercultural en América Latina. Apuntes para su historia" (s.f.), explica cómo la filosofía intercultural es una apuesta programática por transformar la filosofía desde distintas prácticas del filosofar que refieren a la apertura hacia la alteridad como el diálogo entre manifestaciones ontológicas diversas y contextuadas, que en la polifonía pueden aportar a la transformación de la forma como se relacionan las culturas. 
Con la polifonía del diálogo que propone Fornet-Betancourt, la filosofía intercultural quiere «contribuir a equilibrar la humanidad en su pluralidad espiritual y real» (s.f.: 4). Para ello propende por la justicia social, cultural y epistemológica, pero no se reduce a estos componentes, sino que asume compromisos hermenéuticos, al dialogar con las filosofías que reivindican las voces aún no escuchadas, como la filosofía de la liberación y las teorías feministas; por tanto, representa un perfil crítico cultural. El carácter intercultural de la filosofía de Fornet-Betancourt busca cierta acogida en referencia con la participación sociocultural de todos los latinoamericanos, para que realicen aportes desde los distintos escenarios culturales con los que se pueda construir ontologías diversas que entren en diálogo intercultural.

La filosofía intercultural en su ejercicio reflexivo requiere contextualizar las vidas que tejen una trama de realidad dentro de las culturas con las que va a interactuar. Por consiguiente, esta filosofía se compone de «tradiciones de saber o sabidurías que, en cuanto formas de trato con la realidad, son maneras de responder a la pregunta de cómo pensar» (Fornet-Betancourt, s.f.: 7). Gracias a la contextualización, la filosofía intercultural busca establecer diálogos entre distintas tradiciones culturales, para poder escuchar y comprende la voz de los otros.

Sin embargo, es importante aclarar que la filosofía intercultural no busca solamente un diálogo con las culturas latinoamericanas, con sus formas de pensar y sus saberes; esta filosofía realmente se propone un diálogo intercultural universal que traspasa el continente. Por esto, Fornet-Betancourt plantea, dentro de las tareas que tiene la filosofía intercultural, revisar el concepto de filosofía, para entender cómo se ha definido la razón filosófica en un proceso que no requiere comparar las formas de comprender la razón filosófica europeas con las americanas sino, entrar en un proceso de diálogo entre dichas razones. En consecuencia, adelantar un «diálogo directo entre ejercicios de razón filosófica desde los respectivos mundos de vida de los que son elemento constitutivo. Pues es en ellos [...] donde se puede escuchar el real resonar de las razones del otro en nuestro modo de razonar» (Fornet- 
Betancourt, s.f.: 11), un diálogo filosófico en el que los sujetos de cada cultura se reconocen a sí mismos a través del contraste con las diferencias de los otros.

En consecuencia, en el contexto contemporáneo donde tiene lugar la filosofía intercultural, las culturas latinoamericanas aportan al diálogo entre culturas desde la autoderminación de la forma en que viven su espacio y su tiempo, para que «tengan presente y puedan hacer de su presencia en el mundo una forma real de ser y estar en el mundo» (Fornet-Betancourt, s.f.: 9). En este sentido, Fornet-Betancourt re-conoce la vigencia de las culturas autóctonas y afroamericanas en este momento histórico y en este continente compartido con diversas culturas con raíces transcontinentales.

Por tanto, Fornet-Betancourt apela al sentido del término universalidad que hace referencia a la construcción social compartida desde el respeto a la diversidad cultural y la humanitas, cuando reconoce que los filósofos y pensadores que se adscriben y desarrollan un pensamiento en el marco de la filosofía latinoamericana comparten «una visión común que es la de hacer filosofía no por razón de vanidad teórica sino por razón de un auténtico compromiso con la lucha por una humanidad equilibrada y solidaria en su diversidad» (Fornet-Betancourt, s.f.: 20). Este compromiso por hacer justicia a la humanitas de las culturas es reconocido por Cepeda en los siguientes términos:

\footnotetext{
Raúl Fornet-Betancourt insiste

en poner la filosofía

a la altura de las exigencias

del diálogo entre las diversas culturas,

no en abstracto, como un propósito ideal

sino como una tarea concreta

enraízada en el marco histórico

que nos ha correspondido vivir,

que se va aprendiendo, precisamente,

en ese quehacer cotidiano y comprometido

del filosofar
} 
con la realidad

(Cepeda, 2017a: 93).

Es posible reconocer el profundo compromiso ético de Fornet-Betancourt por respetar las tradiciones y las diversas formas de vida de las culturas que dan bases para que sus sujetos se construyan ontológicamente en el espacio-tiempo que significan y, por tanto, se funden como interlocutores que aporten a la autodeterminación de las culturas. En este sentido, la «interculturalidad quiere designar más bien aquella postura o disposición por la que el ser humano se capacita para... y se habitúa a vivir 'sus' referencias identitarias en relación con los llamados 'otros', es decir, compartiéndolas en convivencia con ellos» (Fornet-Betancourt, 2014: 14-15). El filósofo encuentra que esta actitud de diálogo cultural, por un lado, dispone al sujeto a reubicarse cultural y contextualmente y, por otro, le permite ser consciente de su analfabetismo cultural, el cual consiste en considerar que con la propia cultura es suficiente para interpretar el mundo. Esto lo habilita para relativizar sus posiciones, pero también para construir con los otros a partir del reconocimiento de lo que puede aprender en el diálogo constante.

En este contexto el otro es, por tanto, «principalmente allí donde nos sale al encuentro en la alteridad de una forma de vida o cultura, una perspectiva sobre el todo. Y de ahí precisamente su posibilidad de respectivizar nuestra propia perspectiva» (Fornet-Betancourt, 2001: 41). Cada sujeto cultural es entonces una perspectiva del todo, es decir, una ontología en transformación que hace evidente para cada uno la relatividad de su propia cultura y, por tanto, la posibilidad de seguir construyendo con los otros. Aunque no hay que olvidar que «el otro, precisamente por ser sujeto histórico de vida y de pensamiento, no es nunca constituible ni reconstruible desde la posición de otro sujeto» (Fornet-Betancourt, 2001: 42) porque cada uno se forja a sí mismo en el diálogo y la con-vivencia.

Por estas razones, Fornet-Betancourt enfatiza la permanente actualidad que ha de sostener la filosofía intercultural, puesto que para que la filosofía siga el ritmo de la vida «se debe entablar con los filósofos una conversación abierta y crítica en la que ningún sistema o 
filosofía pueda pretender dispensarnos de la obligación de pensar y de recrear la filosofía desde nuestras urgencias» (Fornet-Betancourt, 2014: 10). Las urgencias vitales pueden ser sociales, culturales, religiosas, entre otras, pero siempre impactan directamente la relación del ser de los sujetos con el mundo, siempre desde una ética del respeto al otro y la búsqueda del mejoramiento comunitario y global.

El sujeto capaz de comunicarse desde su identidad y su construcción ontológica con las demás culturas es para Fornet-Betancourt el sujeto comunitario. Para llegar a este sujeto, FornetBetancourt se basa en los planteamientos de Dina Picotti, quien propone el espacio interlógico, el cual es análogo al diálogo eje de la filosofía intercultural. El sujeto comunitario «es sinónimo del diálogo con el otro y con las cosas [...]. No se trata sólo de un diálogo intracultural [...]. El 'sujeto comunitario' es además proceso y proyecto de un diálogo mucho más amplio» (Fornet-Betancourt, 2004: 80). Ese diálogo para Picotti es el espacio interlógico que en términos de Fornet-Betancourt corresponden al mismo diálogo intercultural.

Por tanto, la filosofía intercultural es un saber contextual en el que el sujeto comunitario aporta desde su cultura. Para Fornet-Betancourt esta contextualidad no se refiere a una ubicación geográfica contingente ni mucho menos a una compensación condescendiente hacia algunas culturas, sino que para élen filosofía «la contextualidad es fuente de pluralidad, [...] por razones hermenéuticas y metodológicas, por razones éticas y religiosas, por razones culturales y antropológicas, en una palabra, por razón de lo que llamó Rodolfo Kusch la 'geocultura del pensamiento'» (Fornet-Betancourt, 2001: 13). Esta contextualidad es, entonces, una asunción real del respeto a la autenticidad de cada cultura, para establecer un diálogo desde las diferencias históricas entre manifestaciones humanas diversas de habitar y ser en el mundo.

Un diálogo que siempre apunta hacia la con-vivencia, la cual requiere «esa forma superior de armonía que puede designarse con el nombre de solidaridad. La solidaridad supone y quiere al otro desde su alteridad y exterioridad» (Fornet-Betancourt, 2001: 47), en una premisa del sujeto libre de Fornet-Betancourt que indica el respeto por la libertad de los otros 
para auto determinarse (humanitas), es una característica coherente con la solidaridad como condición para dialogar interculturalmente.

En el diálogo intercultural la verdad no es totalizante ni es patrimonio de una cultura. Por el contrario, se construye en el diálogo entre las verdades provisionales de cada cultura:

Las culturas no dan la "verdad" sino posibilidades para buscarla; referencias para poner en marcha el proceso discursivo hacia la "verdad". [...] Como proceso aparece la "verdad" sólo a condición de que cada uno acepte poner en juego su verdad y la someta a la dialéctica de la contrastación que se crea necesariamente por el carácter interdiscursivo del diálogo intercultural (Fornet-Betancourt, 2001: 48).

A partir del encuentro dialógico es posible sostener una actitud que consiste en «ese elemental darme tiempo para comprender y apreciar al otro, para percibirlo como sujeto que interpela desde su ordenamiento o relación con la historia, el mundo y la verdad; y poder así hacerme cargo de su interpelación» (Fornet-Betancourt, 2001: 52), en una interpelación que invita a participar desde la disposición, propuesta al interior de la filosofía intercultural y apunta hacia el pensamiento solidario de sujetos libres y éticos en el respeto de lahumanitas en relación con alteridades que los confrontan y les aportan. Podemos asir la filosofía intercultural de Fornet-Betancourt como una filosofía pro-posicional en cuya visión se expone «en el sentido de poner a la vista o dar a conocer, pero a la vez también en el sentido de exponer a la influencia... o de abandonar a... la visión y a los 'planes' de cualquier otra filosofía» (FornetBetancourt, 2001: 107-108), resultado de la búsqueda, de la consulta, del consejo y del tratamiento común de lo propuesto, tanto en el saber, como en el actuar. Esta construcción compartida de posibilidades de acción y saberes se dirige hacia la transformación de la vida, en la búsqueda de una actualización cultural a través de la interacción con los otros.

En la apertura del Segundo Congreso Internacional de Filosofía Intercultural, celebrado en Sao Leopoldo-Brasil en 1997, Fornet-Betancourt expuso que «la universalidad del mundo crece desde abajo, desde las experiencias contextuales y desde las memorias plurales de la 
humanidad»(Fornet-Betancourt, 2001: 171-172). Esta preponderancia de la diversidad cultural de Fornet-Betancourt se concreta con el diálogo intercultural entre diferentes tradiciones buscando transformar la vida social y con ello las posibilidades de ser de los múltiples sujetos culturales desde sus contextos habituales. No obstante, la interculturalidad en la que se da el diálogo entre culturas no es un término únicamente racional, lógico o filosófico; Raúl Fornet-Betancourt le da una dimensión más singular al enfocarla en el ser humano dentro de su cotidianidad, por eso, la interculturalidad es entonces «una cualidad que experimentamos en la vida cotidiana en el sentido práctico de que ya estamos en contacto con el otro; y esto en el sentido literal del contacto: relación entre personas/cosas que se tocan» (Fornet-Betancourt, 2001: 257). La interculturalidad es una cualidad que se desarrolla en la praxis sin limitarse a la comunicación racional conceptual, sino que se basa en dejarse afectar, tocar o impresionar por los otros en la vida cotidiana, además de salvaguardar el estar en contacto con el otro que, en últimas, significa la protección de la alteridad en la cual nos reconocemos, nos sabemos distintos y en la que nos configuramos hasta llegar al ámbito ontológico.

La filosofía propuesta por Fornet-Betancourt no se agota en el contexto académico, es un proyecto que busca realmente afectar la vida de las culturas para «transfigurar la figura del mundo haciendo de éste un mundo multiverso en el que en cada uno de sus lugares se realiza y celebra la verdad de cada ser humano como condición de la realización de la verdad de todos» (Fornet-Betancourt, 2001: 17). En resumen, la filosofía intercultural tiende una posibilidad dialógica para expandir las voces de las diversas culturas mundiales, reivindicando la libertad de los sujetos para construir el ser desde la adaptación que hacen de su identidad cultural contextuada y en el descubrimiento de las alteridades de las otras culturas. Estos sujetos han de fundarse como seres libres, éticos en el respeto a la humanitas de los otros y solidarios para dar lugar a la realización de la universalización de la convivencia solidaria, donde sea posible autodeterminarse como sujetos sentipensantes que se construyen ontológicamente en la interacción dialógica dentro y fuera de sus culturas. 


\section{CONCLUSIONES}

La presente investigación cuyas pretensiones por auscultar algunos de los fundamentos ontológicos en la filosofía intercultural de Raúl Fornet-Betancourt, que dan pie para seguir cultivando las semillas ontológicas desde una perspectiva que abraza el sentir intercultural del ser a través del telúrico realismo que encarna América Latina, se consagra como una búsqueda más por develar una vertiente ontológica evocada desde la diversidad cultural adscrita a nuestros suelos, sobre los cuales es posible realizar una lectura de la filosofía intercultural de Fornet-Betancourt en clave plural, a la que quizás ni siquiera el autor haya pensado que podía llegarse.

Durante el desarrollo de este trabajo fue posible adentrarnos en dos disciplinas, especialmente; la primera, es la ontología clásica que posteriormente desencadenará en ontología latinoamericana y la segunda, corresponde propiamente a la filosofía intercultural, que tiene sus antecedentes en la filosofía iberoamericana. Adicionalmente, es determinante analizar cómo estas dos corrientes se han venido transformando a lo largo del tiempo, no solo desde los postulados teóricos sino también desde los lugares donde son enunciadas, axiomas que en la filosofía latinoamericana se gestan dando a luz a nuevas perspectivas del ser que sin duda enriquecen y amplían los focos de estudio, análisis e interpretación de la ontología desde una vertiente intercultural.

La filosofía intercultural como nueva figura filosófica, desde Fornet-Betancourt, se engendra en la novedad y se sustenta desde las prácticas de lo inédito, de lo hasta ahora no pensando en términos filosóficos. Esta propuesta no tiene como fin una reubicación teórica o filosófica sobre la herencia cultural que hemos recibido como pueblo latinoamericano y menos todavía una radicalización netamente discursiva frente a los postulados clásicos de la filosofía. Más bien se trata de impulsar, complementar y potencializar la filosofía en los distintos puntos de encuentro común que no han sido colonizados culturalmente por ninguna tradición cultural. 
Este es el primer sustento base de los siete que Fornet-Betancourt precisa para evidenciar la necesidad de consolidar una filosofía intercultural.

Un nuevo paradigma nos indica Fornet-Betancourt se despliega entonces no solo en la forma de pensar la filosofía desde América Latina, pues a la vez se modifican los procesos ortodoxos de investigación metodológica en ella, renovando la sustancia conceptual del "objeto de interés" y desligando a su vez esta concepción de antaño, por nuevas figuras que legitiman caracteres y repensares de lo concerniente al conocer. Se traslada así la percepción de la "cosa observable" o "el objeto de análisis" hacia un sujeto dialectico, de pensares, sentires y devenires constantes, por medio del cual es posible ausculta el ser en la diversidad sabedora de las culturas.

De alguna manera la filosofía intercultural de Fornet-Betancourt podría interpretarse como una filosofía que rompe con esquemas de pensamiento meramente occidental, estableciendo de entrada un diálogo con nuevos horizontes de comprensión, no solo a nivel discursivo y argumentativo sino también práctico y existencial, frente a la comprensión del ser desde lo intercultural cuyo develamiento surge en el reencuentro de la esencia consigo misma.

El logos filosófico ocupa un lugar secundario en el trasegar de una ontología intercultural, pues las visiones unitarias e inmóviles que filósofos como Parménides propusieron en la antigüedad se desmoronan más allá de la comprensión del ser como unidad estática y absoluta, porque en América Latina un intérprete extiende la discusión ya culminada en Europa acerca de la ontología como fin, como totalidad inmóvil hacia una nueva aprehensión de sentido intercultural, que podría verse no como fin en sí misma, sino como devenir constante que se sostiene un punto de partida que a la vez se convierte en un punto de llegada, es decir, que se recrea en la simpleza de la cotidianidad.

El sustento base señalado por el filósofo cubano radica en la proposición que suscita hablar de "Filosofía Intercultural", pues la sola mención fractura las representaciones que yacen al interior de los esquemas tradicionales de la filosofía clásica, al señalar un camino que se auto- 
renueva en tanto que tiene las herramientas y los actores necesarios para hacerlo. Una filosofía continuamente abierta al cambio y a la convergencia, que convoca las infinitas formas y experiencias filosóficas de vivir la condición humana.

Desde la exposición de los conceptos sustanciales trabajados en el tercer capítulo, cabe resaltar que estos ítems no pueden verse como una sistematización de la información y las razones netamente decantadas desde la lógica occidental. Por el contrario, como insiste Fornet-Betancourt, es desde un "espíritu pionero" donde se intenta aportar a la reflexión filosófica de una nueva mirada que se abre ante el universo intelectual como sapiencia cultural; una nueva atmosfera anímica de las ideas y los argumentos relacionados siempre con las realidades culturales que vislumbran conformaciones diversas del ser.

Dentro de la gran diversidad cultural que encarna América Latina, el punto de encuentro de tantas riquezas cosmogónicas se da en los relatos que las comunidades originarias apalabran, dando evidencia que sus culturas crecieron bajo un yugo dominante que subordinó a pueblos nómadas y aborígenes en el derrotero de la periferia. Esta narrativa que caló en lo profundo de la historia, del relato común del derrotado, jamás reivindicó la legitimidad ancestral de los saberes propios de estas culturas originarias y cuán importantes aportes pueden dar hoy a la luz de nuevas construcciones que re-signifiquen al ser, que poco o nada son tomadas en cuenta por las creencias homogéneas de una sola episteme válida enla atmosfera intelectual.

El desafío señalado por el autor, en el sentido de crear nuevos lenguajes y compresiones dentro de la filosofía, cimienta el reto innovador para la filosofía en general y más aún para la filosofía latinoamericana, puesto que llama a la creación de nuevos paradigmas de lenguajes argumentativos; primero, en la riqueza que podría darse en materia de ampliación teórico-filosófica y segundo, como oportunidad de creación semántica-práctica aplicable a la propia realidad. Al respecto, es necesario aclarar el hecho de que esta postura no intenta romper lazos de comunicación con Occidente, sin embargo, pretende sí elucidar como algo urgente, la edificación de nuevas perspectivas comunicativas que amplíen el horizonte de la filosofía. 
Fornet-Betancourt nos ofrece un panorama de por lo menos cinco conceptos-ejes de análisis que tienen un trasfondo ontológico en su apuesta intercultural; estos apartados están orientados, desde el propio legado histórico de la ontología en relación con la filosofía naciente de las diversas culturas: la Humanitas, la feminidad ontológica, la espiritualidad latinoamericana, la identidad, y la interculturalidad y alteridad entretejen una serie de relaciones sapienciales del sujeto con todo lo que lo rodea y con sigo mismo, legitimando la importancia y el reconocimiento de los saberes ancestrales que desde la diversidad se desarrollan en constante intercambio, en constante relación, en aras de nuevas comprensiones subjetivas que transforman la concepción del ser, desde polifonías geo-culturales.

El esfuerzo del pensador cubano estableció un diálogo entre la tradición filosófica occidental y la filosofía latinoamericana en una conversación dialógica que ha sido primordial para la construcción de los conceptos sobre los cuales se trabaja la fundamentación ontológica de Fornet-Betancourt, dado que recoge desde ambas narrativas filosóficas aspectos sustanciales que enriquecen nuevas comprensiones del ser que transitan por el mundo, la naturaleza y el cosmos, hasta la pregunta por el yo y, sin embargo, detrás de todas ellas siempre está oculta la pregunta por el ser.

Para identificar los sustratos ontológicos en algunos conceptos de la filosofía intercultural de Fornet-Betancourt, ha sido necesario hacer un barrido histórico a nivel ontológico, puesto que la perspectiva filosófica de esta disciplina ha sido influenciada en la presente investigación por Aristóteles y Heidegger, posteriormente por autores latinoamericanos dedicados a trabajar la pregunta por el ser como Vasconcelos, Basave, Estermann, GarciaBacca, Kusch, Cepeda, entre otros, desde donde se nutre la perspectiva ontológica que encontramos serios indicios de que al interior de la obra de Fornet-Betancourt yacen inscritos algunos fundamentos ontológicos propicios para el pensar filosófico en general.

Por ejemplo, la perspectiva Heideggeriana del ser, que se distancia de la metafísica como cuestión óntica al percibir la realidad y se centra en una cuestión meramente ontológica que 
piensa el ser desde la posibilidad que tiene el ente por cuestionarse por aquello de lo cual tiene la capacidad de pensar pero que no está en sí mismo, es un primer paso hacia la búsqueda de lo que, en perspectiva ontológica, puede estar haciendo la filosofía latinoamericana cuando cambia la mirada clásica impuesta y se permite interpretar al ser desde nociones dinámicas de la realidad que confluyen en nuestra cultura. Algunos ejemplos son el ser en la musicalidad de Vasconcelos y su representación en el mestizo, la fuerza del ser en la relacionalidad cultural en Estermann, la posibilidad del ser desde el marxismo de García-Bacca, la habencia como condición libertaria que evoca al ser en Basave, la estancia que reformula la idea del ser en Kusch y la fuerza rítmica autopoiética que Cepeda encuentra en el verso como afinidad con el serear; se constituyen en preceptos que de entrada no se apartan de la cosificación del ser de Occidente, sino que brindan y desarrollan sentires auténticos que trascienden más allá de la estructura racio-céntrica del ser, potenciando nuevas formas de sentipensar lo que es, sin abandonar totalmente el camino ya recorrido.

Esta invitación para andar por nuevos senderos y construir diversos rumbos, se profundiza con el desarrollo de los postulados ontológicos de diversos autores que han dedicado su producción intelectual a la metafísica y cuyas perspectivas amplían el rango del sustrato ontológico que se absorbe en las confluencias de nuevas premisas. A partir de allí, nace una construcción ontológica que lee la filosofía intercultural de Fornet-Betancourt bajo la óptica ontológica influenciada desde la conjunción del territorio latinoamericano. Con base en la hermenéutica textual elaborada en el tercer capítulo, observamos que en la filosofía intercultural de Fornet-Betancourt es primordial la apertura hacia el otro, hacia la pluralidad cultural; esto implica que desde la verdadera disposición toda respuesta a interrogantes ontológicos será provisional, puesto que las culturas y sus sujetos están en permanente transformación. No obstante, en el tejido de las relaciones de los sujetos y las culturas es donde se encuentra el sentido profundo de lo que se es, cómo se es y cómo se debería ser.

Fornet-Betancourt propone la apertura de la pluralidad de voces en un diálogo intercultural donde haya intercambio cultural y construcción de nuevos pactos sociales que configuren otras formas de ser, validando el hecho de que los sujetos sienten su cultura y la piensan, es 
decir, la sentipiensan mientras interactúan con ellos mismos, con su cultura y con lo que les resulta extraño. A propósito, Fornet-Betancourt propende por respetar la especifidad de cada cultura para lograr aportes en el diálogo intercultural hacia la universalización de mejores condiciones de vida. Aquí es donde cobra vital importancia la Humanitas, puesto que en ella se concreta el respeto justo que cada sujeto ha de hacer del proceso de formación vitalexistencial de los demás hombres; este sujeto sentipensante es consciente de que él es construcción biológica y social en relación con los demás en su práctica cultural diaria: su ontología está contextualizada en la cultura de la que hace parte.

En concordancia con lo anterior, el respeto por la construcción ontológica de los sujetos en la interacción es un pilar fundamental para que exista el diálogo intercultural, la polifonía éticamente constructiva que desencadene el potencial cultural de los hombres y en el que desarrollen una metafísica que les permita, a su vez, encarar tanto su humanidad como el lugar al que se circunscriben, sin ser coartados por imposiciones externas dominantes, de tal manera que se transformen en sujetos coherentes con la disposición reivindicativa de las voces culturales, en sujetos afables con la justicia, con el valor ético y con el respeto al derecho de las culturas a re-crearse. Cobran importancia instancias como la feminidad ontológica, en la que se destaca la validez que tiene, tanto para la mujer como para el hombre y para la cultura, abandonar la consciencia de que la mujer es ser para el hombre, para pasar a ser para sí misma, en un giro ontológico que libera al sujeto femenino de un rol sumiso tradicional latinoamericano.

Se observa que en el canon filosófico latinoamericano ha sido usual categorizar el discurso femenino sin atenderlo realmente, sin comprenderlo. En el diálogo intercultural es fundamental que los sujetos se expresen por ellos mismos, por lo que se requiere la participación de la mujer en el diálogo filosófico: la expresión de su ser, de su hacer y de su interactuar en las culturas. Este respeto por la voz de la mujer y por su posibilidad para construirse sin un influjo patriarcal que le determine un lugar en la sociedad es también concreción de la humanitas que da base al diálogo intercultural propuesto por FornetBetancourt. La mujer desde su comprensión e interacción con la imagen que propone para 
ella la sociedad transforma ese ser para otro, para pasar a ser para ella misma y configura su propia ontología cuando se abre a los espacios en los que también su voz debe ser escuchada.

De igual manera sucede con la Espiritualidad latinoamericana, cuya premisa hace inmersión en la filosofía intercultural para lograr comprender el pensamiento de las culturas indígenas y afrodescendientes latinoamericanas, sin lo cual resulta imposible un diálogo en el que los horizontes de comprensión se expandan más allá de los límites filosóficos y culturales occidentales; su necesaria participación se da en términos de disposición real en función de la comprensión que resulta al dejarse afectar por la metafísica cultural de los otros.

De esta forma Fornet-Betancourt se acerca a las teologías indígena y afrodescendiente, para comprender el mundo espiritual como un universo que habita entre los hombres y los conecta con su presente. Es así como el filósofo cubano observa que la teología indígena aboga por su derecho a acercarse a lo divino, a la inconmensurable realidad de Dios, sin una instancia de control teológico cristiana; por tanto, esta teología respeta la construcción ontológica y espiritual de cada pueblo a partir de sus diferentes particularidades; además, la teología indígena es consciente de ser una entre muchas, de ser una parte del entendimiento teológico y, por tanto, respeta la teología de cada pueblo en el momento mismo que busca dialogar espiritualmente con los demás; en consecuencia, esta teología propende por evidenciar la ilegitimidad que tienen las religiones universales, puesto que lo que existe realmente son religiones locales, cada una de las cuales resultan siendo interlocutores totalmente válidos en un diálogo de saberes.

Esta teología, a su vez, es vital porque se manifiesta continuamente en la vida a través del mito, el rito y la simbología, lo que permite a sus sujetos la experiencia de sentipensar su relación con Dios, así como dar significado a las experiencias ontológicas de la vida tanto a nivel individual como comunitario, dado que trata sobre el pueblo y su proyecto de vida, donde Dios está involucrado; finalmente, es una teología ecológica de la liberación de la vida que busca la alianza solidaria entre el ser humano y la naturaleza. 
En cuanto a la teología afroamericana, Fornet-Betancourt encuentra que se caracteriza por hacer un discurso liberador de la palabra negra de y sobre Dios, en el que se honra el carácter histórico que ha tenido la resistencia; es una teología del exilio que reflexiona acerca del destierro y el asedio cultural y religioso. Por otra parte, hace referencia a un Dios único del que no pueden determinarse sus cualidades, mientras se es consciente que ninguna religión debe elevar su pretensión de ser la morada exclusiva de Dios, se convierte en una teología de espiritualización, en la que el ser humano vive en un mundo donde combaten espíritus que pueden mediar ante Dios, en la que hay comunión entre la vida y la religión porque el espacio religioso está presente en todo lo vital, toda vez que el cuerpo humano es visto como sujeto y morada de vivencias, de expresiones religiosas, emotividad y afectividad por medio del baile y el canto en los que el sentido de comunidad se aferra a la vida.

Las teologías indígena y afroamericana integran la espiritualidad dentro de la experiencia cotidiana vital, mientras propenden por el respeto a la posibilidad de cada cultura de acercarse a Dios, abren un posible diálogo teológico en el que se compartan las diferentes concepciones de la relación entre humanidad y divinidad, bajo la premisa de una actitud respetuosa a los otros (humanitas) y la consciencia permanente de vivir en relación con la espiritualidad adscrita a las manifestaciones de Dios. La tendencia a la interacción cultural y al intercambio de estas teologías están en sintonía con el dialogismo que cruza el sistema filosófico de Fornet-Betancourt desde la construcción cultural-ontológica del sujeto hasta llegar a la transformación de la filosofía a través del intercambio disciplinar-filosófico.

Con el mismo énfasis, el eje de análisis Identidad rastrea en América Latina el mosaico de pueblos que requiere ser descubierto en su pluralidad y logra demostrar que es la resistencia de las identidades culturales la que ha permitido prolongar las raíces dentro de las continuas transformaciones comunales. Para reconocer la validez de las culturas, Fornet-Betancourt se apoya en los cuatro criterios de Luis Villoro, a saber: autonomía, autenticidad, sentido y eficacia. Si una cultura goza de autenticidad, sus expresiones tienen como base los deseos, las creencias, las actitudes y las intenciones. 
Fornet-Betancourt se percata de que el sujeto ideal es el sujeto mestizo, ya que ejerce la libertad al construirse en convivencia con otros sin olvidar sus raíces culturales; enraizado a su contexto tiene una ontología construida a partir de la tradición, de la actualización subjetiva individual y, posteriormente, de la apertura al diálogo intercultural. La identidad cultural siempre está en interacción y el escenario más propicio para esta interacción que propone Fornet-Betancourt es el diálogo intercultural, en el cual el multiculturalismo se expanda hacia la pluralidad cultural, hacia las diversas identidades en función de la generación de nuevos pactos sociales. En el diálogo intercultural los sujetos portadores de su cultura reconocen, por una parte, la particularidad dada por una identidad cultural y, por otra, contrastan su pensamiento en los diferentes ámbitos de la experiencia humana con las miradas ajenas.

En relación con la Interculturalidad y alteridad, Fornet-Betancourt concibe la filosofía intercultural como una apuesta por renovar la filosofía al tener en cuenta las distintas prácticas del filosofar de las culturas de la humanidad, al plantearse una apertura hacia la alteridad propio del diálogo entre manifestaciones ontológicas diversas y contextuadas que, en la polifonía, pueden aportar a la transformación de las formas como se relacionan entre sí.

El carácter intercultural de la filosofía de Fornet-Betancourt tiene afiliación con la participación sociocultural de los latinoamericanos, estableciendo diálogos entre distintas tradiciones culturales, para escuchar y comprende la voz de los otros, al intentar lograr, además, un diálogo intercultural universal que cruce continentes. Por esto, Fornet-Betancourt plantea levantar un puente entre ejercicios de razón filosófica desde los respectivos mundos de vida de los que son elementos constitutivos en el que los sujetos se reconozcan a sí mismos a través del contraste diferencial.

En este contexto, Fornet-Betancourt reconoce la vigencia de las culturas autóctonas y afroamericanas en la actualidad frente a los saberes de culturas transcontinentales, porque, en últimas, el compromiso es de respetar las tradiciones y las diversas formas de vida de las 
culturas que dan bases para que sus sujetos se construyan ontológicamente como interlocutores que aporten a la autodeterminación de las culturas.

La actitud de diálogo le permite al sujeto ser consciente de su analfabetismo cultural, a sabiendas de que su propio mundo no le es suficiente para la comprensión universal y lo habilita para relativizar sus posiciones, pero también para construir con los otros a partir del reconocimiento de lo que puede aportar en el encuentro divergente. Cada sujeto cultural es una perspectiva del todo, una ontología en transformación que hace evidente para cada uno la relatividad de su propia cultura y, por tanto, la posibilidad de seguir construyendo en conexión. La interculturalidad es además una cualidad que se desarrolla en la praxis sin limitarse a la comunicación racional conceptual, sino que se basa en dejarse afectar, tocar o impresionar por los otros en la vida cotidiana en función de alcances más globales que permitan consolidar los lazos de la humanidad. 


\section{REFERENCIAS BIBLIOGRÁFICAS}

Aguayo, E. (sf). Agustín Basave Fernández, Del Valle (1923-2006). Enciclopedia de la filosofía mexicana. México: Siglo XX.

Aguilar, J. A. (2003). Después de la raza cósmica: respuesta a mis críticos. Debate. Edición 22. Centro de Investigación y Docencia Económicas, México, 147.

Astrain, R. S. (2003). Filosofia intercultural, globalizacion e identidad. reflexiones sobre el desarrollo desde america latina. Exposición presentada en el seminario : Quelle globalisation pour l'Amérique latine. Débat autour des identités socio-culturelles, Louvain-la-Neuve, Seminario de investigación del Groupe des Recherches Interdisciplinaires sur l'Amérique latine.

Basave, del Valle, A. (1955). Teoría del Estado: Fundamentos de Filosofía Política. México: Jus.

Basave, del Valle. A. (1962). Óntica Antropológica. Revista de filosofía DIÁNOIA, 1962 Vol. $8, n^{\circ} 8$.

Basave, del Valle. A. (1979). Posibilidad y límites de una filosofía latinoamericana. En: Sociedad Venezolana de Filosofía (ed.), La filosofía en América. Trabajos presentados en el IX Congreso Interamericano de Filosofía.

Basave, del Valle. A. (1984). Tratado de metafísica. Teoría de la "habencia". México: Limusa.

Bolaños, E. (2016). Estamos Siendo. Bogotá: USTA.

Burgos, G., \& Martín, M. (2015). Amor y tiempo en la ciudad de Dios de San Agustín. Tiempo y espacio, 1(14), 43-53. Chillán- Chile.

Cáceres, I. (2102). Identidad... ¿latinoamericana?: Diálogos de Multiplicidades. Academia Libre y Popular Latinoamericana de Humanidades. Bogotá: Casa del libro.

Castellanos, B. (2015). El Inconsciente Ontológico de Gilles Deleuze. Por una ontología política frente al psicoanálisis culturalista. Ed. Dykinson. Madrid.

Cepeda, H., Juan (2010). Ontología del estar: una aproximación a la obra de Rodolfo Kusch. Bogotá: USTA. 
Cepeda H, Juan. (2012). Ontología indígena. Aproximación filosófica a saberes precolombinos que posibilitan una ontología latinoamericana. En "Aproximaciones ontológicas a lo latinoamericano". Rosario: Fundación Ross. [pp 15-42].

Cepeda H, Juan. (2013a). ¿Cómo surge el ser? Revista Quaestiones disputatae, 13, 03-103. Bogotá: USTA.

Cepeda H., Juan y otros. (2013b). Aproximaciones ontológicas lo latinoamericano I. Rosario, Argentina: Fundación Ross.

Cepeda H, Juan. (2017 a). Sentipensar Ontológico. Bogotá: Autores Editores.

Cepeda H., Juan. (2017 b). La ontología de Rodolfo Kusch. Mándala ontológico de la filosofía latinoamericana. Bogotá: USTA.

Dussel, E. (2006). De la fraternidad a la solidaridad (hacia una política de la liberación). Pasos, 126, 45-99. San José, Costa Rica.

Estermann, J. (1998). Filosofía Andina: Estudio intercultural de la sabiduría autóctona. Quito: Abya-Yala.

Estermann, J. (2008). Si el sur fuera el norte: chakanas interculturales entre Andes y Occidente. Quito: Abya Yala.

Estermann, J. (2014). Colonialidad, descolonización e interculturalidad. Apuntes desde la Filosofía Intercultural. Polis, Revista Latinoamericana, Volumen 13, No 38 Suiza: Universidad de Lucerna.

Estrella, A. (2009). El legado filosófico de José Vasconcelos. Perspectivas desde una historia social de la filosofía mexicana. Universidad Cádiz, España.

Fornet-Betancourt, R. (2001). Transformación Intercultural de la Filosofía. Bilbao: Desclée de Brower.

Fornet-Betancourt, R. (2004) Crítica intercultural de la filosofía latinoamericana actual. Madrid: Trotta.

Fornet-Betancourt, R. (2006). La inteculturalidad a prueba. Concordia, reihe monographien - Band 43. Mainz.

Fornet-Betancourt, R. (2008). Modelos de teoría liberadora en la historia de la filosofía europea. Hondarribia: Hiru. 
Fornet-Betancourt, R. (2009 a). Interculturalidad crítica y descolonización - fundamentos para el debate. Instituto Internacional de Integración del Convenio Andrés Bello, 71, 72. La paz, Bolivia.

Fornet-Betancourt, R. (2009 b). Tareas y propuestas de la filosofía intercultural. Concordia, Reihe monographien - Band 49. Mainz.

Fornet-Betancourt, R. (2009 c). Mujer y filosofía en el pensamiento iberoamericano: momentos de una relación difícil. Barcelona: Anthropos.

Fornet-Betancourt, R. (2012). Prólogo. En Beuchot, M., Cepeda, J., Picotti, D., Mejía, M., y Moreno, C. Aproximaciones ontológicas lo latinoamericano I (pp. 9-11). Córdoba: Fundación Ross.

Fornet-Betancourt, R. (2017). La filosofía intercultural desde una perspectiva latinoamericana. Solar, 3, 23-40. Lima.

Fornet-Betancourt, R. (s.f.). La filosofía intercultural en América Latina. Apuntes para su historia.

García. Bacca J. D. (1939). Introducción al filosofar. Universidad Nacional de Tucuman (Facultad de filosofía y letras).

García, Bacca, J. D. (1964). Metafísica natural estabilizada y problemática metafísica espontánea. México: Fondo de Cultura Económica.

García, Bacca, J. D. (1982). Antropología filosófica contemporánea: diez conferencias. Barcelona: Anthropos.

García, Bacca, J. D. (1987). Elogio de la técnica. Barcelona: Anthropos.

García, Bacca, J. D. (1990). Nueve grandes filósofos contemporáneos y sus temas. Barcelona: Anthropos.

Gilson, E. (2005). El ser y los filósofos. Navarra: Eunsa.

Grondin., J. (2006). Introducción a la metafísica. Barcelona: Herder.

Guldberg, H. C. (2010). Dificultades teórico metodológicas de la propuesta intercultural. Artículo de investigación, que se enmarca en la amplia serie de estudios que ha realizado el Dr. Horacio Cerutti. N 76 USTA, Bogotá.

Heidegger, M. (2001). Conferencias y artículos (E. Barjau, Trad.). Barcelona: Ediciones del Serbal. (Trabajo original publicado en 1954) 
Heidegger, M. (2003). Introducción a la metafísica (A. Ackermann, Trad.). Barcelona: Gedisa. (Trabajo original publicado en 1935).

Heidegger, M. (2004). Lógica. La pregunta por la verdad (A. Ciria, Trad). Madrid: Alianza. (Trabajo original publicado en 1976).

Heidegger, M. (2006c). Aportes a la filosofía. Acerca del evento (D. Picotti, Trad.). Buenos Aires: Biblos. (Trabajo original publicado en 1989).

Heidegger, M. (2007b). Carta sobre el «humanismo», en: Hitos (H. Cortés \& A. Leyte, Trads.). Madrid: Alianza. (Trabajo original publicado en 1976).

Heidegger, M. (2011). La historia del ser (D. Picotti, Trad.). Buenos Aires: El Hilo de Ariadna. (Trabajo original publicado en 1998).ma

Kusch, R. (1976). Geo Cultura del Hombre. Buenos Aires: Garciá Cambeiro.

Kusch, R. (2000). America Profunda - obras completas tomo II. Rosario: Fundación Ross.

Márquez-Fernández, Á. (2013). Filosofía de la alteridad intercultural en América Latina. Las Torres de Lucca, Revista $n^{\circ}$ 2, 7. Madrid.

Mignolo, W. (1995). Occidentalización, Imperialismo, Globalización: Herencias Coloniales y Teorías Postcoloniales. Revista IberoAmericana - Duke University.

Panikkar, R. (2006). Cultura e Interculturalidad. Cuadernos Interculturales, 129.

Sandoval, J.G. (2018). Fundamentos Ontológicos En La Filosofía Andina De Josef Estermann. Bogotá: USTA.

Sartre, J. (2004). El existencialismo es un humanismo. (A. Sartre, Ed., \& M. C. Llerena, Trad.) Madrid: Edhasa.

Trejo, R. (2010). Filosofía y vida: el itinerario filosófico de José Vasconcelos. Salamanca: Universidad de Salamanca.

Vallescar, D. d. (2001). Coordenadas de la interculturalidad. Diálogo Filosofico, 386.

Vasconcelos, J. (1929). Tratado de metafísica. Editorial "México joven." en Obras Completas, Tomo III, (México, 1959).

Vasconcelos, J. (1939). Ética. en Obras Completas, tomo HI, ed. clt., p. 718.

Vasconcelos, J. (1948). La Raza Cósmica. Misión de la raza iberoamericana. Buenos Aires: Espasa-Calpe. 
Wimmer, F. M. (1995). Filosofía Intercultural ¿Nueva disciplina o nueva orientación de la filosofía? Revista de Filosofía Universidad de Costa Rica.

Zea, L. (1990). Descubrimiento e identidad latinoamericana. Colección 500 años después. México: UNAM

Zea, L. (1993). Filosofar a la altura del hombre México. Cuadernos Americanos. México: UNAM. 